\title{
MONITORAMENTO DE ÁREAS RESTAURADAS NO INTERIOR DO ESTADO DE SÃO PAULO, BRASIL
}

\section{LUDMILA PUGLIESE DE SIQUEIRA}

\author{
Dissertação apresentada à Escola Superior de \\ Agricultura "Luiz de Queiroz", Universidade de São \\ Paulo, para a obtenção do título de Mestre em \\ Recursos Florestais, com opção em Conservação de \\ Ecossistemas Florestais.
}

\section{PIRACICABA}

Estado de São Paulo - Brasil

Abril - 2002 


\title{
MONITORAMENTO DE ÁREAS RESTAURADAS NO INTERIOR DO ESTADO DE SÃO PAULO, BRASIL
}

\author{
LUDMILA PUGLIESE DE SIQUEIRA \\ Bióloga
}

Orientador: Prof. Dr. RICARDO RIBEIRO RODRIGUES

\begin{abstract}
Dissertação apresentada à Escola Superior de Agricultura "Luiz de Queiroz", Universidade de São Paulo, para obtenção do título de Mestre em Recursos Florestais, com opção em Conservação de Ecossistemas Florestais.
\end{abstract}

\section{PIRACICABA}

Estado de São Paulo - Brasil

Abril-2002 


\title{
Dados Internacionais de Catalogação na Publicação (CIP) DIVISÃO DE BIBLIOTECA E DOCUMENTAÇÃO - ESALQ/USP
}

\author{
Siqueira, Ludmila Pugliese de \\ M onitoramento de áreas restauradas no interior do Estado de São Paulo, Brasil / \\ Ludmila Pugliese de Siqueira. - - Piracicaba, 2002. \\ 116 p. \\ Dissertação (mestrado) - - Escola Superior de A gricultura Luiz de Queiroz, \\ 2002. \\ Bibliografia. \\ 1. Banco de sementes 2. Comunidades vegetais 3. Ecologia florestal 4. Manejo \\ florestal 5 . Monitoramento ambiental 6 . Reflorestamento I. Título
}

CDD 634.94

\section{"Permitida a cópia total ou parcial deste documento, desde que citada a fonte - $O$ autor"}


Às primeiras pessoas que leram estas páginas, João Marcos e Magaly, e aos meus queridos irmãos,

Lara, Lê e Lico, com todo o meu amor e gratidão, dedico. 
Agradecimentos

Ao professor Ricardo Ribeiro Rodrigues pela oportunidade de desenvolver este trabalho e pela confiança que depositou em mim;

Ao professor Sergius Gandolfi pela "co-orientação", valiosas explicações, sugestões e correções;

Ao professor João Batista pelo auxílio nas análises dos dados, pelas discussões e contribuições à dissertação;

À Fundação de Amparo à Pesquisa do Estado de São Paulo pela bolsa de estudos concedida;

Ao João Marcos de Siqueira pelas sugestões, por ler e reler e corrigir a tese e por tantos outros favores!!;

A Magaly Pugliese de Siqueira pela assessoria na parte de Línga Portuguesa;

Ao Fabiano Antonio Rodrigues (Roko) por fazer o Banco de Dados e me incentivar a usá-lo; e ainda estar sempre disponível para resolver qualquer "probleminha" do sistema;

A Fabiana Arantes Basso pela indispensável ajuda no infindável trabalho de separação das sementes e colaboração nas atividades de campo;

Aos primos, Soninha e Renato, pela alegria e companheirismo com que me acolheram nos primeiros meses desta jornada e pela constante torcida!;

A Terezinha Pugliese pelo empréstimo do carro durante o período de mestrado, sem o qual este trabalho seria bastante dificultado, e por todo apoio e interesse;

Ao Zé (Zandoval) por me auxiliar e agüentar no trabalho de campo, com tanta disposição;

Ao pessoal da Botânica: Tereza, Tirolês, Pequeno e Chaddad pelos muitos "galhos quebrados";

Ao Geraldinho (Geraldo Franco) pelo auxílio na identificação das espécies; 
Ao Ivo por sua paciência e presteza na realização de tantas funções (imprimir, escanear, gravar, tocar pagode e etc);

A Ritinha pela sincera amizade construída desde dos tempos de Poço, por estar sempre presente me incentivando e ajudando; por me deixar à par dos eventos científicos, oportunidades de cursos, empregos e etc.!;

A Beth, pelo nosso grupo de estudo do Begon, que me motivou a fazer o Mestrado em São Paulo, e pelas festas em Campinas;

A Andrea (por mim e pelo Roko) por permitir que fizéssemos parte do seleto grupo dos "Amigos da Andrea"; pelas caronas de Americana para Piracicaba e pelas boas risadas e mergulhos em Iracemápolis!!;

A Flaviana por me resgatar de "alguns" apuros; pelo impréstimo dos artigos e da Tese; por ter me levado para nossa casa e pela boa convivência;

A Alessandra, por me aceitar sabendo respeitar nossas diferenças, tornado a convivência agradável;

Ao Daniel, eterno vizinho do Rio, pelas noitadas, comentários dos filmes e por tantas conversas tão ricas e detalhadas, que me fazem entender mais da vida e natureza humana;

A lldinha, por ser minha segunda mãe e pelo indispensável arroz, feijão e couve;

Aos amigos de Pira que estiveram comigo durante estes dois anos, tornando a vida mais fácil: Viviane (Nhoq), a "grande família" Fernanda, Marcelo e Felipe, Anna Julia, Valéria, Gustavo (Beija-Flor), ao casal Paulo (Nelore) e Paula, Carla Gheler; Rose e todo o pessoal da turma de pós-graduação;

A Silvana, por dividir momentos de alegria, angustia, aflições e tantas outras coisas, e é claro, pelas baladas fortes!!;

Novamente ao Fabiano (Roko), pela presença tão necessária e ativa; pela simplicidade e harmonia de nosso convívio durante estes anos; Ah! E pelas caronas, pelo computador, pela máquina fotográfica, pela trena, pelo auxílio em campo e principalmente pelos palpites no trabalho e na vida...;

E por fim, a meus pais e irmãos por serem não somente minha família, mas por me apoirem e participarem tão intensa e carinhosamente de todos os momentos de minha vida. 


\section{SUMÁRIO}

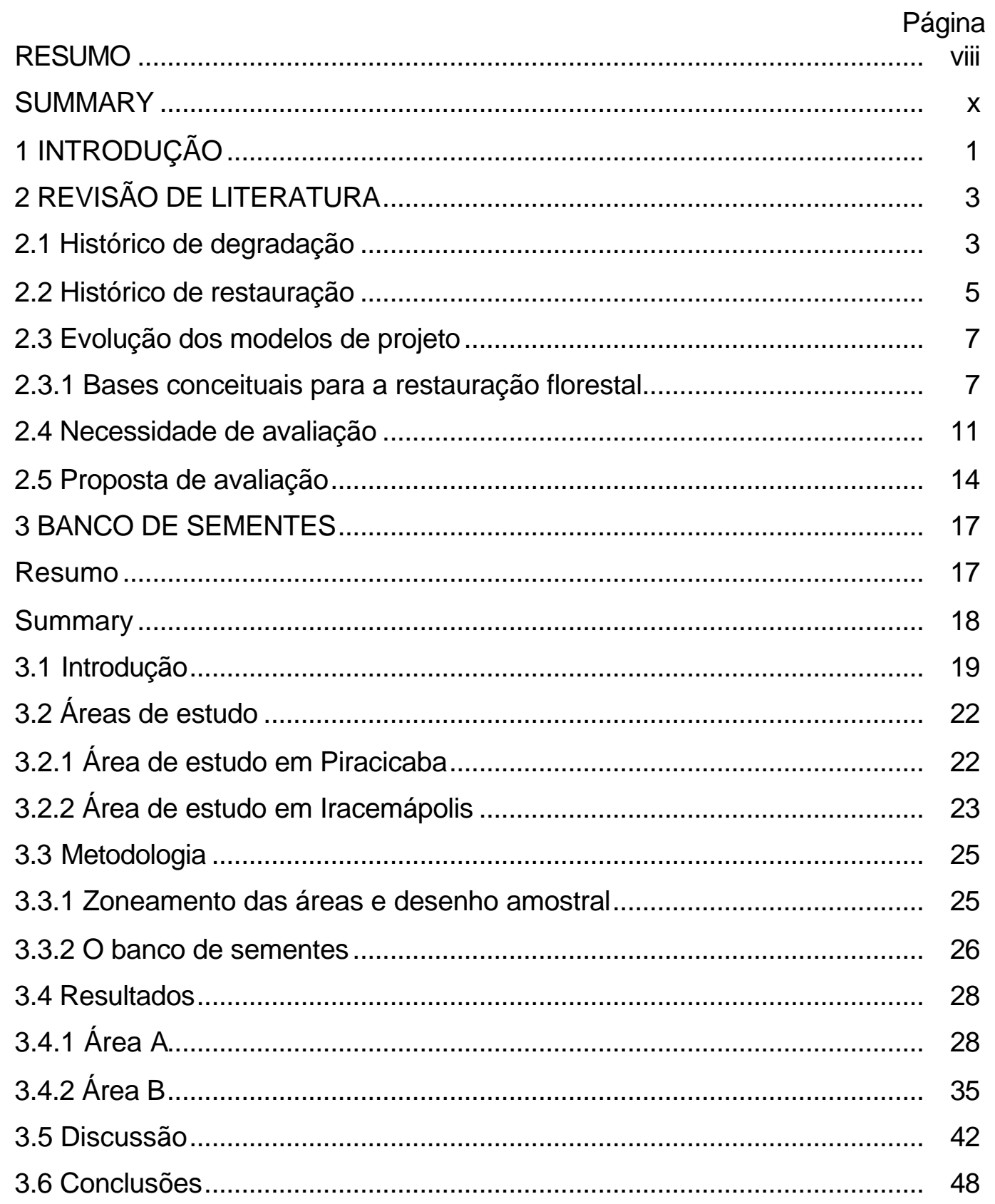


4 CHUVA DE SEMENTES ................................................................ 50

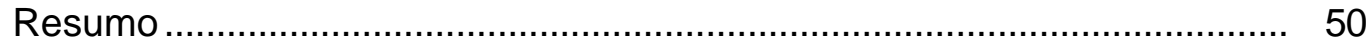

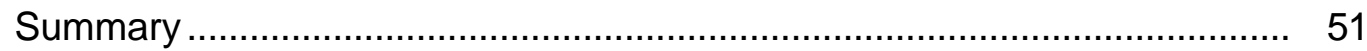

4.1 Introdução .............................................................................. 52

4.2 Área de estudo ..................................................................... 54

4.3 Metodologia .......................................................................... 56

4.3.1 Zoneamento das áreas e desenho amostral................................... 56

4.3.2 A chuva de sementes ..................................................................... 57

4.4 Resultados ......................................................................... 58

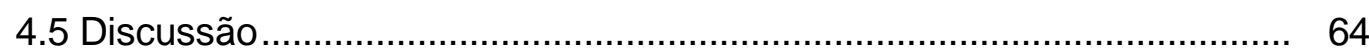

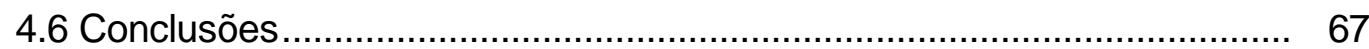

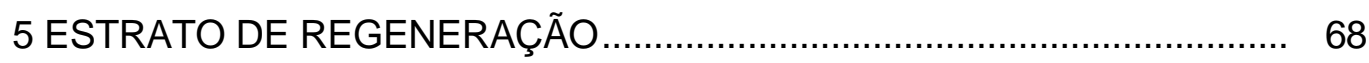

Resumo ........................................................................................ 68

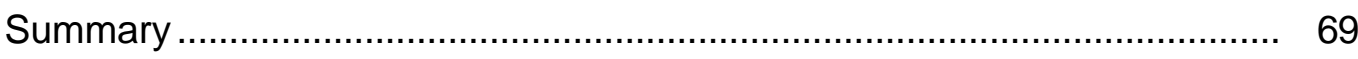

5.1 Introdução ............................................................................. 70

5.2 Áreas de estudo ........................................................................... 72

5.2.1 Área de estudo em Piracicaba......................................................... 72

5.2.2 Área de estudo em Iracemápolis ..................................................... 74

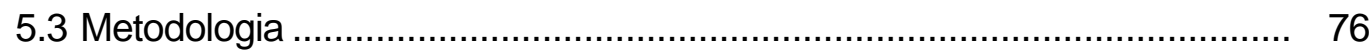

5.3.1 Zoneamento das áreas e desenho amostral................................... 76

$5.3 .2 \mathrm{O}$ estrato de regeneração ............................................................ 77

5.4 Resultados..................................................................................... 78

5.4.1 Área A

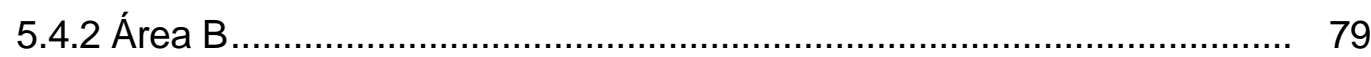

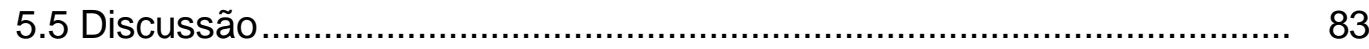

5.6 Conclusões .................................................................................... 88

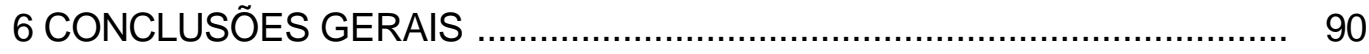

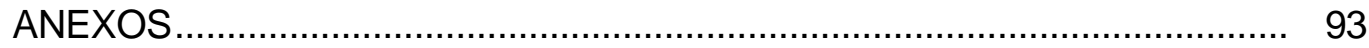

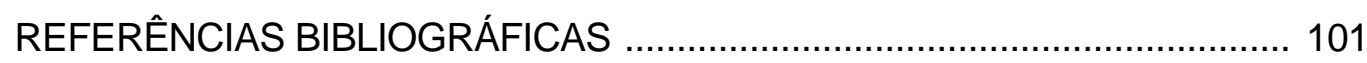




\title{
MONITORAMENTO DE ÁREAS RESTAURADAS NO INTERIOR DO ESTADO DE SÃO PAULO, BRASIL
}

\author{
Autora: LUDMILA PUGLIESE DE SIQUEIRA \\ Orientador: Prof. Dr. RICARDO RIBEIRO RODRIGUES
}

\section{RESUMO}

O estudo teve por objetivo analisar alguns aspectos de dinâmica florestal que pudessem ser utilizados no monitoramento de áreas restauradas. O plantio destas áreas foi baseado no mesmo modelo de restauração. Tal modelo está fundamentado em conceitos de sucessão secundária, utilização preferencial de espécies nativas regionais, e parâmetros de densidade dos indivíduos conforme encontrado para os remanescentes florestais da região. A primeira área (área A) está situada a margem esquerda do rio Piracicaba, na área urbana deste município. No plantio desta área foram utilizadas 35 espécies. Esta área foi plantada em 1991, estando com 10 anos na época em que foi realizado o estudo. A segunda área (área B) está situada às margens da represa de abastecimento municipal de Iracemápolis. O plantio desta área, onde foram utilizadas 140 espécies, teve início em 1987 apresentando, aproximadamente, 14 anos na época em que foi realizado o estudo. Em cada uma destas áreas, foram instaladas 10 parcelas de $10 \times 10 \mathrm{~m}$, dentro das quais foram alocadas, de forma aleatória, 9 subparcelas para avalição dos indicadores selecionados. $O$ banco de sementes foi avaliado mediante 30 amostras de solo em subparcelas de $0,25 \times 0,25 \mathrm{~m}$ realizadas nas estações chuvosa e seca de 2001. A chuva de sementes foi quantificada mensalmente através da amostra do material depositado em 30 coletores 
de $0,5 \times 0,5 \mathrm{~m}$. Para a amostragem do estrato de regeneração foi realizado 0 levantamento de todos os indivíduos entre 0,30 e $2 \mathrm{~m}$ presentes dentro de 30 subparcelas de $1 \times 1 \mathrm{~m}$. O banco de sementes da área $A$ apresentou densidade média de 328,53 sementes. $\mathrm{m}^{-2}$ na estação chuvosa e de 245,87 sementes. $\mathrm{m}^{-2}$ na seca. $\mathrm{Na}$ área $\mathrm{B}$ a densidade encontrada nas amostras do banco de sementes foi 1.131,73 sementes. $\mathrm{m}^{-2}$ na estação chuvosa e 685,30 sementes. $\mathrm{m}^{-2}$ na estação seca. Não foi verificada variação sazonal no banco de sementes para as duas áreas. A maior parte das espécies encontradas no banco foi caracterizada como herbácea. $\mathrm{Na}$ análise da chuva de sementes foram verificadas variações sazonais na frutificação e espaciais na dispersão das sementes. A densidade média de sementes depositadas no período de um ano foi de 591,33 sementes. $\mathrm{m}^{-2}$. A maior porcentagem de indivíduos depositado nos coletores apresentou síndrome de dispersão zoocórica. Espécies iniciais foram predominantes na chuva de sementes. O estrato de regeneração da área $A$ apresentou baixa riqueza de espécies, sendo a maior parte dos indivíduos amostrados pertencentes a uma única espécie, Leucaena leucochephala. Nesta área foram encontrada apenas 2 espécies e a densidade obtida foi inferior a um. $\mathrm{Na}$ área $\mathrm{B}$ foram encontradas 15 espécies de 11 famílias, sendo a densidade média obtida igual 1 indivíduo. $\mathrm{m}^{-2}$. Os resultados indicam que na área $B$ foi possível criar uma ambiente favorável a regeneração natural e que na área $A$ esta regeneração pode estar sendo limitada em função da agressividade e atividade alelopática da Leucaena leucocephala. Também o número inicial das espécies, a idade e o tamanho das áreas, a qualidade do terreno e a intensidade de manejos anteriores podem influenciar este resultado. Dentre os indicadores selecionados, o estrato de regeneração foi o mais confiável para o monitoramento das áreas. 


\title{
MONITORING OF RESTORED AREAS IN THE INTERIOR OF SAO PAULO STATE, BRAZIL
}

\author{
Author: LUDMILA PUGLIESE DE SIQUEIRA \\ Adviser: Prof. Dr. RICARDO RIBEIRO RODRIGUES
}

\section{SUMMARY}

The study was seeking to analyze some aspects of forestry dynamics that could be used in monitoring restored areas. The planting of these areas was based on the same restoration models. Such models are based in concepts of secondary succession, regional native species preferential usage and density parameters of the individuals as it's found for the forestry remains in the region. The first area $(A)$ is located at the left margin of the Piracicaba River, in the urban area of this town. In the planting of this area 35 species were used. The area was planted in 1991, being 10 years old by the time of the study. The second area (B) is located at the margins of the city water supply dam in Iracemápolis. The planting of this area, where 140 species were used, began in 1987, being around 14 years old when the study was performed. In each of these areas, ten $10 \times 10 \mathrm{~m}$ parcels were installed, inside of which nine sub-parcels for evaluating the selected indicators were randomly placed. The seed 
bank was evaluated by 30 soil samples in 0,25 x 0,25m sub-parcels, performed in the dry and wet seasons in 2001. The seed rain was monthly quantified through samples of the material allocated in thirty $0,50 \times 0,50 \mathrm{~m}$ collectors. For the regeneration stratum sampling, a counting of all the individuals between 0,30 and $2 \mathrm{~m}$ was performed, inside thirty $1 \times 1 \mathrm{~m}$ sub-parcels. The seed bank in area A showed average density of 328,53 seeds. $\mathrm{m}^{-2}$ in the rainy season and 245,87 seeds. $\mathrm{m}^{-2}$ in the dry one. In area $B$, the density was $1.131,73$ seeds. $\mathrm{m}^{-2}$ in the rainy season and 685,30 seeds. $\mathrm{m}^{-2}$ in the dry one. Seasonal variation in the seed bank was not verified for both areas. Most of the species found in the bank was classified as herbaceous. In the seed rain analysis, seasonal variations in fruiting were verified, likewise spatial ones in the seeds dispersion. The average seeds density found within a year period was 591,33 seeds.m ${ }^{-}$ 2. The highest percentage of individuals found on the collectors showed zoochoric dispersion syndrome. Early species were majority in the seed rain. The regeneration stratum in area A showed low species diversity, being the majority from a unique species, Leucaena leucochephala. In this area, only two species were found and the average density was below one. In area B, 15 species of 11 families were found, being the average density equals one individual. $\mathrm{m}^{-2}$. The results show that in area $B$ it was possible to create a favorable environment to a natural regeneration, and in area $A$ this regeneration can be limited due to the Leucaena leucochephala aggressiveness and alelopathic activity. Also, the initial number of the species, the age and the size of the areas, the quality of the land and the intensity of previous management can influence the results. 


\section{INTRODUÇÃO}

A atual crise de energia que atinge o país não é resultante apenas de secas atípicas ou de má gestão governamental. Dentre as causas mais relevantes desta questão, um importante papel deve ser atribuído a fatores responsáveis pela escassez de água nos reservatórios. Afinal, é esta a força motriz para as Usinas Hidrelétricas geradora de grande parte da energia consumida no Brasil.

O desmatamento tem sido apontado como um dos grandes vilões desta história. Em áreas onde a cobertura vegetal não está presente, a água proveniente das chuvas escorre superficialmente sobre o solo, levando a processos erosivos, de assoreamento e deposição do material carreado nas regiões de baixada. $O$ saldo é um menor abastecimento dos lençóis freáticos bem como a maior incidência de enchentes.

A necessidade de reverter $\mathrm{o}$ atual quadro de desmatamento promove o desafio de recuperar as florestas, principalmente aquelas próximas a mananciais hídricos, garantindo desta forma um maior abastecimento dos reservatórios. De fato, ações como estas já foram implantadas em alguns locais, sendo registradas em tempos mais antigo, como no caso do reflorestamemto da Floresta da Tijuca catado do período imperial, ocasionada pelos mesmos motivos observados hoje em dia.

Se a preocupação com as funções do ecossistema foi o principal incentivador das ações de recuperação, outras questões foram, por conseqüência, favorecidas. Assim é clara a contribuição de projetos de recuperação para a conservação da biodiversidade (Keenan et al., 1997), seqüestro de carbono (Silver et al., 2000) melhoria da qualidade de vida, dentre outros tantos benefícios

Além dessas questões práticas, projetos de restauração oferecem oportunidade de questionamentos teórico sobre processo em nível populacional (Montalvo et al., 1997), de comunidade (Palmer, 1997), de ecossistema (Ehrenfel \& Toth, 1997) e de 
paisagem (Bell et al., 1997). Ações restauradoras possibilitam ainda realização de diversos estudos experimentais e desenvolvimento de hipóteses ligado as áreas de ecologia.

A constatação dos benefícios trazidos pela recuperação de áreas degradadas por parte da sociedade civil e da mídia, somada às exigências legais tornaram estas iniciativas cada vez mais difundidas, principalmente nos últimos vinte anos. Podemos destacar, como exemplo, programas de organizações não governamentais, empresas privadas, consórcio de bacias, governos municipais, estaduais e federais bem como proprietários rurais.

A Restauração Florestal, como tem sido denominada a área da ciência que abrange toda ação de recuperação ambiental, é ainda uma atividade recente (Palmer, 1997). Os modelos e conceitos teóricos de implantação empregados nestes projetos ainda estão sendo testados e discutidos em âmbito acadêmico. Muitos trabalhos já formam desenvolvidos baseados em diferentes metodologias de acordo com as idéias do pesquisador ou empreendedor responsável e principalmente de acordo com a disponibilidade de recursos financeiros.

Para que os estudos e trabalhos realizados nesta área possam avançar, faz-se necessário, nesta etapa, a avaliação e o monitoramento dos projetos de recuperação já em andamento. Esta avaliação, deve ter como objetivo a verificação do cumprimento das metas pré-estabelecidos em cada projeto ou, pelo menos, a evolução dos processos neste sentido.

No Brasil poucos são os trabalhos desenvolvidos com este fim. A maior parte destes preocupa-se apenas com a transformação ambiental e aspectos estruturais e menos com a questão do restabelecimento dos processos ecológicos e funções do ecossistema, fundamentais para a restauração ambiental.

Baseado nestas constatações, este estudo foi desenvolvido com o objetivo de avaliar se os processos ecológicos foram restabelecidos em duas áreas restauradas no interior do estado de São Paulo, com diferentes idades mas onde foram utilizadas as mesmas metodologias na implantação. Ainda como objetivos pretende-se verificar se os indicadores escolhidos para a avaliação permitem inferir sobre a sustentabilidade das áreas e se as metodologias utilizadas nos projetos de restauração possibilitam atingir as metas preestabelecidas. 


\section{REVISÃO DE LITERAT URA}

\subsection{Histórico de degradação}

A necessidade de aumento da produção agrícola e pecuária na última metade do século passado, dada a crescente demanda populacional, motivou a ocupação de novas áreas, florestadas, e sua transformação para o cultivo e produção agropecuária. Esta medida de incremento às atividades sócio-econômicas trouxe como resultado a redução, fragmentação e o isolamento de paisagens, principalmente naquelas áreas ocupadas por florestas de caráter tropical.

Após o período de utilização da terra, que por vezes é bastante reduzido, estass podem ser abandonadas em função de dois principais aspectos. O primeiro destes refere-se às características intrínsecas da região, primariamente ligadas às condições do solo. Este pode não ser apropriado ao tipo de cultura empregado ou ser inadequadamente utilizado para este fim. Em tais casos, os nutrientes do solo são rapidamente exauridos, gerando a redução ou perda de produtividade da área.

O segundo aspecto está relacionado com questões externas, de demanda de mercado. Muitas vezes, por ocasião de flutuações no mercado consumidor, os produtores são obrigados a alterar sua atividade por outras mais rentáveis naquele momento. Em ambos casos, ou as áreas são negligenciadas (Leopold et al., 2001) ou são transformadas para diferentes fins, de acordo com o interesse local. No sudeste do Brasil, por exemplo, muitas destas áreas foram incorporadas ao perímetro urbano, em função da expansão de suas malhas.

Em alguns casos onde as áreas são abandonadas, decorridos alguns anos, após cessarem os fatores de perturbação (ex. atividades agrícolas e pecuária), formam-se capoeiras ou florestas secundárias (Brown \& Lugo, 1990; Wijdeven \& Kuzee, 2000). 
Estas áreas representam importante papel socio-ambiental servindo de refúgio para plantas e animais, atuando na contenção de encostas, proteção a mananciais, seqüestro de carbono, reduzindo os níveis deste gás na atmosfera, além de servir como área de recreação à população. (Brown \& Lugo, 1990; Finegan, 1992; Aide et al., 1995; Silver et al., 2000). Mesquita (2000) ressalta ainda o potencial para exploração econômica de florestas secundárias na Amazônia, através da produção de madeira e produtos madeireros obtidos nestes locais.

Porém, em todo mundo as florestas são convertidas para diferentes usos (Füher, 2000) e na maioria dos casos, no entanto, o processo exploratório é tão agressivo que a capacidade de resiliência da área é afetada. Nestes casos, a regeneração natural é impossibilitada dado ao alto nível de dano ambiental.

Os principais fatores que limitam restabelecimento de uma floresta foram bastante estudados e são bem conhecidos em literatura. Dentre as causas mais apontadas podemos citar: a ocupação e dominância de espécies exóticas e daninhas; compactação, empobrecimento e contaminação do solo; ausência e inutilização do banco de sementes; distância de fontes de propágulos; ausência de dispersores; condições inadequadas à germinação de sementes e reincidência de incêndios (Uhl et al., 1988; McClanahan \& Wolfe, 1993; Parrota et al., 1997b; Aide et al., 2000, Finegan \& Delgado, 2000; Wijdeven \& Kuzee, 2000). Um exemplo claro dessa situação é observado em áreas de mineração e em áreas de empréstimos, onde se somam muitas das situações apontadas anteriormente.

As conseqüências da devastação florestal incluem redução e isolamento de populações vegetais e animais (Saunders, 1991; Primack, 1993), gerando conseqüências genéticas deletérias com possível perda de espécies (Bierregaard et al., 1992; Turner, 1996; Laurence, 1998; Didham, 1999; Manson et al., 1999; Scariot, 1999). Observam-se ainda, nestas áreas degradadas, mudanças na estrutura e função do ecossistema, assim como de processos ecológicos tais como sucessão secundária, teias tróficas, bem como relações de interações, a exemplo da polinização e dispersão. Alterações microclimáticas, como mudanças nos padrões de intensidade solar, fluxo de ventos e umidade, também são esperadas e sem dúvida afetam ainda mais a comunidade biótica local (Matlack, 1993; Murcia, 1995; Laurence, 1999).

Os problemas ocasionados com a degradação ambiental, principalmente a questão da redução da biodiversidade e fatores que afetam diretamente o homem, 
como a alteração dos ciclos de água e do carbono, estão ultimamente em evidência na mídia. Esta exposição das conseqüências nocivas das atividades exploratórias do homem sobre ele próprio, levou a uma mudança de postura de parte da sociedade frente estas atividades. E não apenas isso. Exigências legais foram formuladas visando minimizar, dificultar e mesmo impedir a realização de ações que atentem contra o meio ambiente.

\subsection{Histórico de restauração}

Ações de caráter conservacionista são fundamentais para a proteção dos remanescentes florestais. Entretanto, elas não são suficientes para reverter as perdas e danos já ocorridas no ecossistema. Com este fim, é necessário uma intervenção mais efetiva, sendo a restauração florestal uma das atividades mais promissora neste sentido.

A restauração florestal no Brasil, tem seu primeiro registro histórico datado do Período Imperial. Problemas de abastecimento de água na cidade do Rio de Janeiro, então sede da Coroa Portuguesa, suscitou do governo imperial as providências legais para proteção e reflorestamento de matas no entorno de nascentes (Martins,1988). A recomposição florística dos mananciais, principalmente na Floresta da Tijuca, foi efetuada inicialmente com o transplante de pequenas árvores e posteriormente mudas, obtidas em área vizinhas. Por fim, observando-se grande perda de indivíduos, optou-se pela coleta de sementes, formação de mudas em viveiros e seu plantio aleatório nas áreas (Castro Maya, 1976). Este procedimento permitiu o sucesso da iniciativa do Major Archer e seus poucos ajudantes, como pode ser comprovado no Parque Nacional da Floresta da Tijuca.

As atividades restauradoras que se seguiram, a partir da primeira metade do século XX, não só no Brasil mas em outros países como Costa Rica, México, África e Austrália, primaram pelo plantio em monocultura, usualmente de espécies exóticas, tal como o Pinus e Eucalyptus. A utilização destas espécies está relacionada a sua alta taxa de crescimento que permite o recobrimento da área em um menor espaço de tempo. Associado a este fato, podemos citar como vantagem deste modelo de restauração, o rendimento econômico proporcionado pela utilização das madeiras para fins comerciais . 
Os restauradores esperavam que, após certo período, estas áreas evoluíssem para uma floresta nativa (Gandolfi \& Rodrigues, 1996). Este aumento da riqueza de espécies ocorreria em função do recrutamento natural, quer pelo banco de sementes autóctone ou pelo chegada de propágulos de regiões próximas, ou mesmo através de sucessivos plantios, passados alguns anos de implantação (Augusto et al., 2001).

O fato do potencial de plantações comerciais atuarem como catalizadores do processo sucessional e permitirem, desta forma, a recolonização da floresta nativa tem sido demonstrado em diversos estudos (Chapman \& Chapman, 1995; Keenan et al., 1997; Powers, 1997; Murcia, 1997; Lugo, 1997; Geldenhuys, 1997; Leopold et al., 2001). Estas espécies catalizadoras, rapidamente criariam condições favoráveis para o estabelecimento de plântulas e atrairiam agentes dispersores de sementes que poderiam enriquecer a área, trazendo propágulos de fontes próximas (Parrota, 1997b).

O plantio em monoculturas de espécies exóticas tem sido bastante discutido em literatura e até certo ponto com algum criticismo. Reis e colaboradores (1999) enfatizam a questão de que muitas espécies exóticas apresentam caráter agressivo, impedindo assim o recrutamento de novas espécies, podendo mesmo alterar o processo de sucessão vegetal na área. Num estudo conduzido por Jurado (1998), no México, sobre uma plantação comercial de Leucaena, por exemplo, observa-se que a taxa de regeneração sob esta espécie foi baixa para a maioria das outras espécies. Este estudo, assim como os de outros autores avaliando o comportamento de espécies exóticas, confirma sua dominância sobre as da flora regional.

Lugo (1997), por sua vez, indica que as principais questões levantadas contra a utilização destas culturas incluem impactos sobre as condições ambientais locais, essencialmente na disponibilidade de água e características físicas e químicas do solo, baixa biodiversidade e possível invasão destas espécies exóticas em áreas de floresta natural. Atenta-se, também, para o fato de que espécies exóticas podem não apresentar agentes polinizadores e dispersores correspondentes na fauna local. Esta lacuna prejudicaria o desenvolvimento da vegetação nativa bem como deixaria de fornecer recursos para os animais na área.

Guariguata \& Pinard (1998) discutem que para ocorrência de regeneração natural em plantações manejadas, com fins de extração seletiva de madeira, é necessário mais do que a proteção de áreas dentro destas florestas. Estes autores prosseguem afirmando que o entendimento e a aplicação da ecologia de sementes 
poderia ajudar nas prescrições de manejo para este fim. Augusto et al. (2001) ressaltam ainda que a colonização do solo por propágulos de áreas vizinhas pode ser muito lenta e não será possível se não houver floresta nativa próxima a área considerada.

\subsection{Evolução dos modelos de projeto}

A partir da década de 80 , observa-se então uma alteração fundamental com relação aos conceitos de restauração, enfatizando o uso de espécies nativas em plantios mistos, bastante divulgados e discutidos no Congresso de Espécies Nativas (1982) e no Simpósio de Matas Ciliares (1989) (Kageyama \& Gandara, 2000). Constata-se, apartir daí, uma tendência dos projetos de restauração privilegiarem espécies nativas e utilização de padrões espaciais de distribuição das espécies. Este procedimento difere do ocorrido nos primeiros plantios mistos conhecidos no Brasil, efetuados na Floresta da Tijuca, Itatiaia e Cosmópolis, que foram completamente aleatórios e admitiram o uso de espécies exóticas.

\subsubsection{Bases conceituais para a restauração florestal}

O maior problema a ser defrontado por uma proposta de restauração pode ser resumido em três questões básicas (Rodrigues e Gandolfi, 1996): i) Quais espécies plantar ?; ii) Quanto plantar de cada espécie; iii) Qual a melhor maneira de efetivar um projeto de restauração, num menor espaço de tempo, com menos perdas e custos. De acordo com estes autores, para resolver tais questões é fundamental o conhecimento de três aspectos relacionados à ecologia vegetal: a fitogeografia, a fitossociologia e a sucessão ecológica.

A observação de padrões e processos naturais tem auxiliado na compreensão de tais questionamentos e, muitas vezes, tem atuado como modelo para ações mais efetivas de restauração. 


\subsubsection{Sucessão secundária}

O desenvolvimento de vegetação em áreas de pasto ou campos agrícolas abandonados é fruto de intensa investigação, na tentativa de entendimento da

dinâmica de sucessão. A compreensão deste processo é feita dentro da perspectiva de identificar a melhor estratégia para a restauração de áreas degradadas (Parker, 1997; Aide et al., 2000; Wijdeven \& Kuzee, 2000).

Esta mudança na composição das espécies vegetais, ao longo do tempo, que é a própria sucessão secundária, tem sido explicada através de múltiplos mecanismos. Clements (1916), citado por Begon et al. (1996), indica que se trata de uma seqüência de substituição, na qual, cada estágio constrói a base para o seguinte, a exemplo de um super-organismo. Gleason (1926) e Whittaker (1975), também citados por Begon et al. (1996), afirmam ser os padrões de respostas diferencial de cada espécie com relação às mudanças ambientais, os responsáveis pelas mudanças vegetacionais. Connel \& Slatyer (1977) indicam o modelo de Facilitação /Inibição.

Em florestas maduras, a ocorrência de clareiras é um processo bastante comum e exerce papel fundamental na renovação da vegetação. A dinâmica de regeneração, que ocorre neste ambiente, é semelhante ao processo de sucessão em áreas abandonadas e, como tal, é fruto de diversas explicações, como pode ser observado através dos trabalhos de Denslow (1980), Whitmore (1982), Gandolfi (1991).

Independentemente do caso, quer em grandes áreas abandonadas ou em pequenas clareiras no interior da mata, e da explicação que se dê para a sua ocorrência, o fato é que há um aumento e substituição de espécies nestas áreas. Estas espécies podem ser agrupadas em grupos ecológicos distintos, conhecidos como categorias ou grupos sucessionais (Budowski, 1965; Swaine \& Whitmore, 1988), que são a base do processo de sucessão (Gandolfi \& Rodrigues,1996).

Entretanto, parte do problema em se restaurar áreas, utilizando-se nosso conhecimento atual de sucessão está nesta questão da divergência de opiniões sobre o Paradigma da Sucessão (Pickett et al., 1992). Não há um consenso, por exemplo, sobre o grau de auto regulação do sistema e nem se este atingirá um clímax estável, através de uma seqüência fixa e obrigatória de substituição de espécies (Pickett \& Ostefeld, 1994). A visão determinista de Clements não é universalmente aceita e 
alguns autores como Palmer e colaboradores (1997) afirmam que os distúrbios naturais devem fazer parte dos esforços de restauração.

Afora estas questões, que envolvem conceitos sobre balanço da natureza, os modelos sucessionais são largamente adotados como subsídios às práticas de

restauração. Áreas de referência são utilizadas para a avaliação de sucesso de projetos bem como são feitas projeções que admitem composições florísticas finais, ou climax, após determinado tempo (Parker, 1997).

\subsubsection{Flora regional - fitogeografia}

Tendo como base o modelo de sucessão, indicado como estratégia para restauração, o passo seguinte refere-se ao conjunto de espécies que serão utilizadas nos projetos. Como dito anteriormente, a maioria dos projetos hoje em dia, privilegia as espécies da flora regional, apesar de algumas divergências como em Kendle \& Rose (2000).

As formações vegetais, encontradas nos diferentes locais, são fruto de distintos fatores geográficos e ambientais, especialmente macroclimáticos, além da performance diferencial de cada espécie. Sabe-se também que as espécies encontradas em determinado local são as mais bem adaptadas para o conjunto de variáveis locais, uma vez que foram selecionadas evolutivamente. Com base nestas observações, é de se supor que num projeto de restauração, as probabilidades de sucesso estão vinculadas a utilização de espécies nativas regionais, dada a complexidade de processos e a quantidade de variáveis envolvidas no sistema.

Adicionalmente temos, nos reflorestamentos, um importante colaborador para conservação da biodiversidade, não apenas em relação ao número de espécies mas também com relação à diversidade genética (Barbosa, 2000). Por fim, num projeto de restauração tem-se, por definição (Jackson et al., 1995), que serão restabelecidos a função, os processos e estrutura de uma floresta natural. Portanto é fundamental que a biota regional seja reestruturada, incluindo fauna e flora bem com suas inter-relações.

Por tais motivos, muitos projetos têm sua lista de espécies baseadas em levantamentos florísticos, feitos em áreas próximas ao local da área a ser restaurada. 


\subsubsection{Distribuição espacial das espécies - fitossociologia}

Sabendo-se quais espécies serão utilizadas no projeto, resta saber como serão arranjadas no campo, considerando-se para tanto, a distribuição de cada indivíduo com relação aos demais. Muitos modelos são propostos de acordo com o objetivo do projeto, disponibilidade de mudas ou sementes, recursos financeiros, tempo, proximidade com vegetação natural e grau de degradação da área em questão.

Em casos onde a área foi completamente degradada, sem qualquer possibilidade de regeneração, a menos que ocorra a intervenção humana, é comum a utilização do modelo de consórcio de diferentes espécies arbóreas. Segundo Rodrigues \& Gandolfi (2000) estes modelos podem ser implementados no campo através de módulos de combinação de espécies ou linhas alternadas de plantio.

Os módulos representam a unidade de plantio, onde as espécies são combinadas considerando diferentes aspectos (Rodrigues \& Gandolfi, 2000). Assim, pode-se combinar espécies, considerando os aspectos adaptativos, agrupando-as de acordo com exigências ambientais. Também a combinação de espécies pode ser de acordo com os aspectos de diversidade, incluindo espécies de um único grupo ecológico formando ilhas de diversidade, ou em casos onde capoeiras são enriquecidas com espécies finais.

Por fim, temos os modelos sucessionais que misturam espécies de diferentes categorias sucessionais, na tentativa de dar à regeneração artificial, um modelo seguindo os processos naturais, como o de dinâmica de clareiras e sucessão secundária (Kageyama e Gandara, 2000). O plantio em módulos com o objetivo de criar uma unidade independente de sucessão possibilita que os parâmetros populacionais sejam reproduzidos, incluindo padrões de densidade, diversidade, distribuição espacial e adaptabilidade (Rodrigues \& Gandolfi, 1996).

O plantio em linhas não possibilita tal reprodução de padrões, apesar de ser mais facilmente implantado no campo sendo, portanto, mais indicado para plantios em largas escalas (Kageyama e Gandara, 2000). 


\subsection{Necessidade de avaliação}

É importante que as ações de restauração tenham sucesso, pois de outra forma os recursos e esforços que poderiam ser usados para outros fins estariam sendo desperdiçados. Entretanto, existem muitos projetos para os quais se desconhece se alcançaram seus objetivos, visto que não foram avaliados. Em outros, não há um rigor científico na elaboração dos experimentos (Michener, 1997). Nestes casos, perde-se a oportunidade de se determinar os métodos mais apropriados para a restauração com relação a suas metas específicas.

Uma das maiores questões levantadas em um projeto de restauração é a determinação de critérios que possam ser empregados na avaliação de seu sucesso. Com esta finalidade, foram desenvolvidos diversos estudos nos últimos anos. Jansen (1997), por exemplo, tem demonstrado o efeito da restauração sobre a estrutura da comunidade de invertebrados terrestres. Zou \& Gonzalez (1997) estudaram, especificamente, a mudança na densidade de minhocas em áreas em regeneração. $A$ mesofauna tem sido objeto de estudo em áreas em sucessão e regeneração natural (Koehler, 2000). As características fisico-químicas do solo bem como os microorganismos associados também são utilizados na classificação de habitats (Bentham et al.,1992) .

Os insetos, principalmente formigas, têm sido objeto de estudos na perspectiva de atuarem como indicadores de sucesso de projetos de restauração (Marjer, 1996; Andersen \& Sparling, 1997; Marjer \& Nichols,1998).

Turker \& Murphy (1997) sugerem, além de formigas e invertebrados da serapilheira, a amostragem de grupo de pequenos mamíferos e répteis como indicadores de processos e da dinâmica na comunidade. Van Aarde et al., (1996) e Parrota et al., (1997a) destacam o papel de morcegos e aves em áreas restauradas, como dispersores de sementes podendo, portanto, ser utilizados como bons indicadores de sucesso em projetos de restauração. Robinson \& Handel (1993) e Armstrong \& Nichols (2000) indicam que a complexidade e a diversidade da vegetação são fatores chaves para a recolonização da avifauna. Comunidades de peixes também são utilizadas em áreas ripárias restauradas (Paller et al., 2000).

Em alguns casos, mais de um parâmetro é utilizado na avalição de áreas restauradas. Aronson \& Le Floc'h (1996) sugerem uma série de atributos da paisagem 
que seriam utilizados para este fim como número e variedade de ecótones e corredores, diversidade de grupos funcionais, grau de transformação da paisagem entre outros. O projeto Pen Branch, em desenvolvimento nas áreas inundadas do Rio Savannah, na Carolina do Sul, propõe uma estrutura de avaliação quantitativa composta por uma série de indicadores que poderiam ser utilizados para inferir sobre a eficiência da restauração nestas áreas (Kolka et al., 2000, Barton et al., 2000) . Neste intuito, foram avaliados diferentes parâmetros como: hidrologia, solo, vegetação, ciclo de carbono e nutrientes e a fauna - comunidades de insetos aquáticos, peixes, vertebrados terrestres, artrópodes e macroinvertebrados.

Existem ainda trabalhos que relacionam fotografias aéreas, imagens de satélites, banco de dados e até incidência de incêndios na avaliação de áreas restauradas (Anais do Simpósio Nacional de Recuperação de Áreas Degradadas, 2000).

A imensa maioria dos trabalhos, entretanto, limita as avaliações do sucesso da restauração a comunidade vegetal. Podemos citar como exemplos os trabalhos desenvolvidos por Jansen (1997), Parrota \& Knowles (1999 e 2001), Aide et al., (2000) Finegan \& Delgado (2000), Souza (2000), Leopold et al., (2001). Este fato é claramente entendido, um vez que as plantas são a base de todo processo de restauração (Young, 2000).

Independente do objetivo pretendido de uma ação restauradora, medidas estruturais da comunidade vegetal são freqüentemente as mais utilizadas para avaliar seu sucesso (Ehrenfeld \& Toth, 1997). A maioria dos trabalhos analisa a restauração através de parâmetros estruturais da comunidade vegetal como riqueza, altura, diâmetro, densidade, diversidade, freqüência e área basal. Mesmo em estudos envolvendo sucessão secundária, as características estruturais são privilegiadas com relação às funcionais (Guariguata \& Ostertag, 2001). Isto ocorre uma vez que medidas estruturais são mais facilmente obtidas em comparação a qualquer outro atributo ecológico.

Contudo, é importante salientar que a questão estrutural não representa a totalidade dos objetivos pretendidos pela restauração. Em muitas situações, o objetivo é recriar a composição de espécies e as condições ambientais a fim de permitir que as funções ecológicas do ecossistema (ex. a ciclagem de nutrientes e fluxo de energia) sejam retomadas (Jackson et al., 1995; Kolka, 2000) e que a área se torne auto- 
sustentável (Parker, 1997). Entenda-se por sustentabilidade o estágio no qual não é mais necessária intervenção externa para que o sistema se mantenha.

As funções ecológicas são examinadas através de processos que ocorrem em escala temporal, diferentemente de aspectos estruturais que só requerem a discrição do que está presente num determinado momento, numa escala pontual (Grayson et al., 1999). Por seu caráter temporal a funcionalidade do ecossistema é mais difícil de ser monitorada. Embora estrutura - principalmente com relação a biodiversidade - e funcionalidade possam estar correlacionados, tratam de aspectos distintos e, portanto, não devem ser confundidos (Palmer, 1997).

É evidente que a exemplo de qualquer obra de engenharia, a restauração deve começar pela base estrutural, que neste caso é a vegetação. E esta fase inicial deve sim ser avaliadas através de características descritivas da comunidade. Porém, para se avaliar a funcionalidade é necessário que haja decorrido um maior tempo de implantação do projeto (Kolka, 2000) bem como são necessárias re-medições de atributos através do tempo, a fim de que seja possível reconhecer os processos posteriormente estabelecidos. Portanto a avaliação dos projetos deve estar de acordo com os objetivos pretendidos e com o estágio de desenvolvimento do projeto.

Avaliação de áreas restauradas geralmente requer a comparação dessas com outras de referências. Aqui nós nos deparamos com dois problemas. O primeiro, já comentado anteriormente, é esta questão da estabilidade do sistema. Alguns autores reconhecem que distúrbios e eventos estocásticos, como histórico de perturbação e a probabilidade de chegada de propágulos, podem introduzir uma imprevisibilidade substancial aos modelos de comunidades (Palmer, 1997; Parker, 1997). Tais aspectos tornariam a comparação entre áreas e a avaliação por cronosequência imprópria, já que cada área poderia divergir para pontos distintos.

O segundo aspecto é bastante óbvio, pois trata da área de referência em si, que em muitos casos não existe nas proximidades da área a ser restaurada (Grayson et al., 1999) em função de extensão da devastação das áreas florestadas. Em outros casos, não se sabe o histórico de degradação e estado de conservação das áreas remanescentes, dificultando com isso a sua utilização como modelo. 


\subsection{Proposta de avaliação}

No estudo de florestas manejadas é comum a utilização de uma estrutura conceitual hierarquizada - com princípios, critérios e indicadores ( $P, C$ \& I)- com o objetivo de facilitar o desenvolvimento de um sistema que permita a avaliação da sustentabilidade das áreas (van Bueren \& Blom, 1997). Esta estrutura está baseada na idéia de que o monitoramento deve estar organizado de níveis superiores para inferiores.

Assim, em linhas gerais, temos a definição de princípio, como uma lei ou regra geral como base de raciocínio ou guia de ação. Em seguida temos o critério que pode ser entendido como a característica distinguidora pelo qual determinado aspecto pode ser julgado. Por fim, há o indicador que seria, então, qualquer variável que pode ser medida com relação a um critério.

Os indicadores selecionados devem respeitar algumas características para serem amplamente utilizáveis e aplicáveis (Prabhu et al., 1996): i) ser relevante a questão, ii) estar correlacionado ao critério e este ao princípio; iii) ser precisamente definido; iv) fácil de interpretar, detectar e avaliar; v) ser confiável e vi) ser sensível à metodologia empregada.

Acreditando-se que esta estrutura conceitual é bastante consistente para o planejamento de projetos de avaliação de sustentabilidade, procurou-se orientar a investigação do sucesso da restauração de áreas seguindo este padrão de organização (Figura 1).

A escolha de alguns atributos selecionados merece alguma explicação. Os projetos de restauração que estão sendo avaliados têm como meta a sustentabilidade das áreas. Portanto, o princípio deve ser definido baseando-se neste objetivo préestabelecido. Assim, serão estabelecida como base de raciocínio para as ações, ou princípio, a restauração das funções ecológicas Como dito anteriormente, as funções são avaliadas através de processos, que neste caso vão determinar os critérios mais apropriados de acordo com o princípio. Para um princípio, pode existir uma série de critérios, envolvendo diferente aspectos ambientais, sociais e econômicos. Sendo o processo de sucessão ecológica uma das bases conceituais para a restauração, achou-se por bem determiná-lo como critério. 
Caso a sucessão esteja ocorrendo de forma natural na área, podemos concluir que o projeto está dentro da trajetória esperada, uma vez que a intervenção externa não é mais necessária para que ela ocorra.

Os critérios selecionados, que são a chuva de sementes, o banco de sementes e o estrato de regeneração, são fundamentais para que ocorra a dinâmica de sucessão uma vez que representam o estoque ou reserva potencial de indivíduo para a próxima geração.

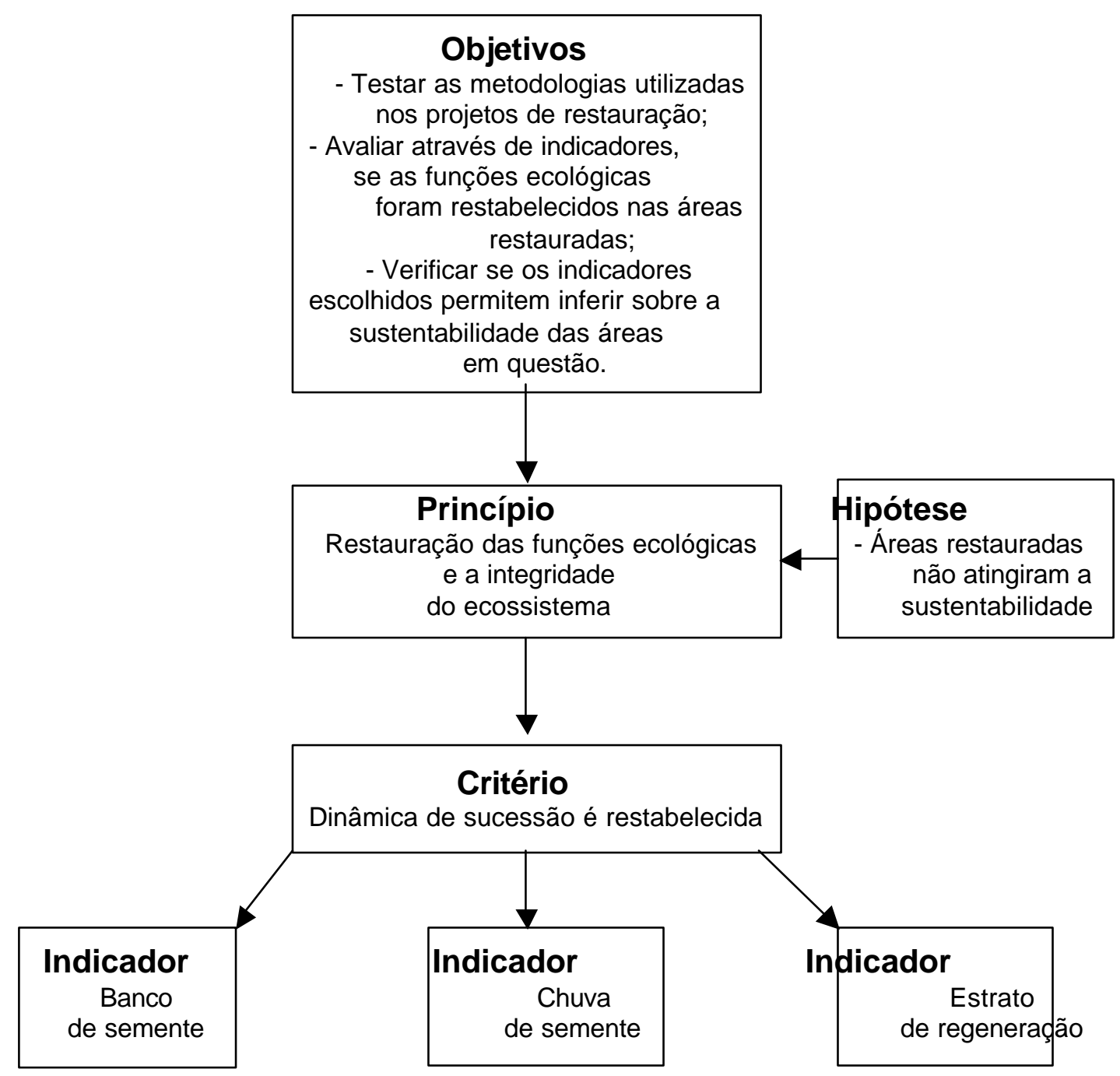

Figura1- Resumo esquemático da estrutura proposta para a avaliação do sucesso de áreas restauradas. 
Com base nesta estrutura bem determinada de avalição, espera-se obter informações acerca do estado de restauração das áreas bem como das metodologias empregadas nas mesmas. Adicionalmente, pretende-se testar a estrutura proposta como modelo para a avaliação de áreas restauradas. 


\title{
3 BANCO DE SEMENTES
}

\author{
Autora: LUDMILA PUGLIESE DE SIQUEIRA \\ Orientador: Prof. Dr. RICARDO RIBEIRO RODRIGUES
}

\section{Resumo}

A composição de espécies do banco de sementes presentes no solo em duas áreas restauradas com diferentes idades de plantio (área $\mathrm{A}$ com 10 anos e área B com 14 anos) foi avaliada mediante utilização do método de germinação de sementes. Em cada uma das áreas, foram coletadas 30 amostras de $0,25 \times 0,25 \mathrm{~m}$ da camada superficial do solo a uma profundidade de $0-5 \mathrm{~cm}$, nas estações seca e chuvosa. As amostras foram postas para germinar em estufas e regadas duas vezes ao dia. $\mathrm{Na}$ área A observou-se a germinação de um total de 616 indivíduos pertencentes a 37 espécies na estação chuvosa e 461 indivíduos pertencentes a 27 espécies na estação seca. $\mathrm{Na}$ área $\mathrm{B}$ foram amostrados um total 2.122 indivíduos pertencentes a 37 espécies na estação chuvosa e 1.285 indivíduos pertencentes a 23 espécies na estação seca. Em ambas áreas a composição do banco de sementes foi dominada por espécies herbáceas, tanto na estação chuvosa quanto na seca. Dentre as espécies arbóreas encontradas verificou-se o predomínio das exóticas nas duas áreas, bem como nas duas estações de coleta. Não foi verificada variação sazonal no banco de sementes das áreas estudadas. A densidade de sementes encontrada foi significativamente diferente entre áreas, sendo igual a 328,53 sementes. $\mathrm{m}^{-2}$ e 245,87 sementes. $\mathrm{m}^{-2}$ para a área $A$, e $1.131,73$ sementes. $\mathrm{m}^{-2}$ e 685,30 sementes. $\mathrm{m}^{-2}$ para a 
area $\mathrm{B}$, nas estações chuvosa e seca, respectivamente. $\mathrm{O}$ índice de similaridade entre as espécies germinadas no banco e a flora implantada na área foi baixo, sendo igual a $3,39 \%$ na área $A$ e 3,50\% na área B. O estudo demonstrou baixa porcentagem de espécies arbóreas presentes no solo das áreas restauradas, tendo a dispersão de sementes papel fundamental no aumento da riqueza de espécies nestas comunidades.

\section{THE SEED BANK}

Author: LUDMILA PUGLIESE DE SIQUEIRA Adviser: Prof. Dr. RICARDO RIBEIRO RODRIGUES

\section{Summary}

The composition of species in the seed bank present in the soil in two restored areas with different planting ages (Area $A$ is 10 years old and area $B$ is 14) was evaluated by using the seeds germination method. In each of the areas, thirty $0,25 x$ 0,25m, $0-5 \mathrm{~cm}$ deep, samples of the soil surface were collected, in both dry and wet seasons. The samples were putting for germination in greenhouses and they were watered twice a day. In area A, we could observe germination from a whole of 616 individuals among 37 species in the rainy season and 461 individuals among 2 species in the dry season. In area B, 2.122 individuals among 37 species in the rainy season and 1.285 individuals among 23 species in the dry season were sampled. In both areas, the composition of the seed bank was dominated by herbaceous species in the dry and wet seasons. Among the tree and shurb species, it was verified a majority of exotic ones in both areas and both harvest seasons. A seasonal variation in the seed bank of the studied areas was not verified. The seeds density was significantly different in both areas, being equals to 328,53 seeds $\mathrm{m}^{-2}$ and 245,87 seeds. $\mathrm{m}^{-2}$ for area $\mathrm{A}$, and $1.131,73$ seeds. $\mathrm{m}^{-2}$ and 685,30 seeds. $\mathrm{m}^{-2}$ for area $B$ in the rainy and dry seasons, respectively. The similarity index among the germinated species in the bank and the 
implanted flora in the area was low, being equals to 3,39\% in area $A$ and $3,50 \%$ in area B. The study showed that the percentage of arboreal species in the soil of restored areas is low, having the seeds dispersion a key role in the increase of richness and diversity in the communities.

\subsection{Introdução}

Muitos autores têm enfatizado o papel do banco de sementes na dinâmica vegetal (Roizman, 1993; Baider, 1994; Bakker, 1996; Nepstad et al., 1996; GromboneGuaratini, 1999; Rodrigues, 1999; Onaindia \& Amezaga; 2000), como subsídio para que ocorram os processos de regeneração e sucessão. Guariguata \& Pinard (1998) indicam que a regeneração pode ser mais eficientemente planejada se as informações sobre o banco de sementes forem incorporadas ao programa de manejo da área. Neste sentido, é importante conhecer a composição florística, abundância e taxa de "turnover" do banco de sementes presentes em cada área (Garwood, 1989).

O recrutamento de novos indivíduos de algumas espécies tropicais, especialmente aquelas de estágio inicial de sucessão depende, em parte, do banco de sementes que pode permanecer dormente, até que surjam condições favoráveis para sua germinação e estabelecimento (Young et al., 1987; Lunt, 1997). Outras formas de regeneração são observadas, principalmente em pequenas clareiras, através de rebrotas (Penha, 1998), expansão lateral das copas (Alvarez-Buylla, 1996) ou desenvolvimento de banco de plântulas ou indivíduos jovens, conhecido como regeneração avançada (Denslow, 1987).

Entretanto, em locais onde foi desenvolvida intensa atividade exploratória ou em grandes áreas devastadas, estas demais formas de regeneração são bastante improváveis de ocorrerem (Uhl et al., 1988; Baider et al., 1999).

Nestes casos, a disponibilidade de sementes no solo pode ser um fator limitante para a regeneração destas áreas (Skoglund, 1992).

Wijdeven \& Kuzee (2000) sugerem que a disponibilidade de sementes no banco pode ser caraterizada por três componentes: a presença, o ganho e a perda de sementes. $O$ balanço entre estes componentes irá determinar a taxa de mudança ou "turnover" do banco em um determinado local. 
A presença é determinada pela assembléia de semente viáveis na área, resultante de processos de perdas e ganhos, passados e presentes, bem como a longevidade diferencial de cada espécie a ser considerada em cada situação (LopezMarinho et al., 2000).

O incremento do número de sementes no banco pode se dar através da chuva de sementes de indivíduos autóctones ou alóctones. Neste último caso, agentes dispersores como aves e morcegos exercem papel fundamental no deslocamento de propágulos. Em áreas tropicais, mais da metade das espécies vegetais têm suas sementes dispersadas por animais (Howe \& Smallwood, 1982; Wunderle, 1997). Predominantemente, porém, a dispersão local é a que ocorre mais freqüentemente, condicionando o alcance das sementes a pouca distância da matriz que a produz.

A perda de indivíduos do banco de sementes pode estar relacionada a uma série de fatores como a própria germinação, predação, parasitismo e senescência (Hyatt \& Casper, 2000). O recrutamento de sementes do banco é restrito a períodos com condições ambientais favoráveis, que incluem variáveis associadas a temperatura, luz, umidade, solo além dos padrões sazonais de germinação de cada espécie.

O aumento na intensidade de luz e temperatura estimula a germinação de sementes presentes no solo (Vázquez-Yanes \& Orozoco-Segovia, 1994). Muito embora esta seja uma questão bastante discutida em literatura (ex. Guariguata, 2000), assume-se que a maior parte das sementes, formadoras do banco, pertença a espécies de estágio inicial de sucessão.

Alguns autores têm demonstrado baixo índice de correlação existente entre o banco de sementes e a vegetação já estabelecida em florestas naturais (Thompson \& Grime, 1979, Guo et al., 2000; Tekle \& Bekele; 2000). Onaindaia e Amezaga (2000) sugerem que esta diferença possa estar relacionada ao regime de luz. As espécies que dominam o dossel de florestas secundárias influenciam na disponibilidade de luz para os estrato inferiores (Guariguata \& Osterga, 2001). Uma vez que altos níveis de luminosidade são necessários para a germinação de espécies pioneira, a redução de intensidade de luz favorece a formação do banco por estas espécies. As espécies do dossel, por outro lado, geralmente pertencem a estágios mais avançados de sucessão.

Esta constatação é particularmente importante em áreas de manejo de espécies exóticas, em que se pretende recuperar o sub-bosque natural, utilizando-se para este fim o banco de sementes, remanescente na área (Augusto et al., 2001). 
Tekle \& Bekele (2000) discutem que esta correlação pode variar em função dos diferentes tipos de vegetação, paisagem, grau de distúrbios ou intervenção humana e que provavelmente o banco de sementes não servirá como única solução para a restauração da área.

Relações entre a persistência no banco e tamanho de sementes também são objeto de divergentes opiniões. Entretanto, sementes persistentes no banco tendem a apresentar tamanhos reduzidos de sementes, enquanto que, espécies de baixa permanência no banco parecem apresentar tamanhos comparativamente maiores (McDonald et al., 1996).

As sementes podem permanecer viáveis no solo por décadas (Thompson \& Grime, 1979) e uma série de funções ecológicas e genéticas tem sido proposta para explicar esta longevidade (Hyatt \& Casper, 2000). O banco de sementes pode atuar como reserva genética, reduzindo a probabilidade de extinção de determinadas espécies, facilitar a coexistência entre espécies competidoras e servir como fonte de propágulos para a comunidade em casos de distúrbios, mudanças ambientais e regeneração. Por tais motivos o banco de sementes pode ser considerado um mecanismo de escape temporal (Alvarez-Buylla \& Martinez-Ramos, 1990).

Estudos recentes, entretanto, têm demonstrado que o banco de sementes é muito mais dinâmico do que se admitia, como pode ser observado nos trabalhos de Alvarez-Buylla \& Martinez-Ramos (1990), Dalling et al. (1997 e 1998).

O presente estudo está baseado na hipótese de que o banco de sementes possa fornecer indicativos sobre a capacidade de regeneração da área. Tem ainda como objetivo:

i) Avaliar a capacidade de regeneração das áreas restauradas através da presença, ou não do banco de sementes;

ii) Verificar se há efeito sazonal no banco provocado pela variação entre o período chuvoso e de estiagem em duas estações do ano (seca e chuvosa);

iii) Verificar se o banco de sementes constituiu um bom indicador para a avaliação de sucesso de projetos de restauração. 


\section{2 Áreas de estudo}

O estudo foi desenvolvido em duas áreas restauradas no interior de São Paulo. A primeira destas localiza-se na cidade de Piracicaba e segunda no Município de Iracemápolis. Apesar de apresentarem diferentes idades de plantio (a primeira área com 10 anos e a segunda com 14 anos), estas áreas foram restauradas baseadas no mesmo modelo de restauração. Este modelo está fundamentado nos conceitos de sucessão secundária, utilização de espécies nativas regionais e padrão de disitribuição espacial dos indivíduos de acordo com os parâmetros quantitativos e sucessionais das espécies encontradas nos remanescentes florestais da região.

A seguir estão relacionadas as características específicas de cada uma destas áreas. A área de estudo em Piracicaba será identificada como área $\mathrm{A} e \mathrm{a}$ área de estudo em Iracemápolis como área B.

\subsection{1 Área de estudo em Piracicaba}

- Localização geográfica e caracterização física

A primeira área localiza-se na cidade de Piracicaba, situada à $22^{\circ} 42^{\prime} \mathrm{S}$ de latitude e, $47^{\circ} 38^{\prime} \mathrm{W}$ de longitude.

O estudo foi conduzido numa área restaurada à margem esquerda do Rio Piracicaba, dentro do perímetro urbano numa área de aproximadamente 2,4 há, com $370 \mathrm{~m}$ de comprimento e largura variável de 15 e 75 m (Anexo B). Esta área é limitada de um lado pelo rio Piracicaba e de outro por uma avenida, denominada avenida Bandeirantes. O plantio desta região foi realizado em 1991, estando no ano de coleta de dados com 10 anos de idade.

Esta região apresenta clima, Cwa segundo Köpen, caracterizado como mesotérmico ou sub-úmido, de inverno seco, com temperatura média do mês mais frio inferior a $18^{\circ} \mathrm{C}$ e a média do mais quente entre $23^{\circ} \mathrm{C}$ e $24^{\circ} \mathrm{C}$. A pluviosidade média anual nesta região é de 1.200 a $1.300 \mathrm{~mm}$.

Antes da instalação do projeto de restauração, o solo das covas onde seriam plantadas as mudas foi trocado, pois a área era utilizada para despejo de restos de material de construção. As covas foram então preenchidas com latossolo vermelho trazido de áreas de empréstimo. 
- Caracterização do projeto de restauração

No início do reflorestamento havia uma cobertura vegetal presente na área que era composta basicamente de vegetação herbácea, alguns aglomerados de leucena (Leucaena leucocephala), remanescente de ingá (Inga vera) e aproximadamente 200 indivíduos de espécies nativas, resultantes de um plantio simbólico. Todos os indivíduos arbóreos existentes foram mantidos.

Como dito anteriormente, privilegiou-se na escolha as espécies nativas regionais, considerando ainda aspectos sucessionais e parâmetros quantitativos dessas espécies nos remanescentes florestais da região (Rozza et al., 1992).

As espécies foram agrupadas em módulos de nove indivíduos, num espaçamento de 2,5 × 2,5m. Em cada módulo foram implantados 6 indivíduos de pioneiras, 2 secundárias iniciais e uma secundária tardia ou clímax. Nesta área foram utilizadas 35 espécies, numa densidade de $1.600 \mathrm{ind} / \mathrm{ha}$. A lista de espécies utilizadas no plantio é apresentada em anexo (Anexo A).

Em função da interferência causada pelas flutuações do nível da água do rio, foram criadas duas diferentes sub-áreas: sub-área I, adjacente ao curso de água, numa faixa de $5 \mathrm{~m}$, onde foram introduzidas espécies típicas de condição ciliar, adaptadas a períodos variáveis de inundação do solo; e sub-área II que fica paralela a primeira, possuindo espécies típicas de Floresta Estacional Semidecídual (IBGE,1993), não sujeitas à encharcamento do solo.

O plantio apresenta-se hoje com dossel a uma altura média estimada em $9 \mathrm{~m}$ (levantamento de 200 indivíduos) (Anexo C). O subosque nesta área é bastante aberto em função de roçadas e cortes freqüentes, promovidos por funcionários da prefeitura, para manutenção da limpeza e segurança no local .

Numa faixa de aproximadamente 5 metros ao longo do Rio há um predomínio da espécis Leucaena leucocepha, não só na área área de plantio mas ao longo de toda sua extensão, formando um aglomerado que domina a paisagem. Entretanto, é possível verificar diversar espécies utilizadas no plantio quando nos aproximamos da sua faixa mais externa, próxima a avenida Bandeirantes.

\subsection{2 Área de estudo em Iracemápolis}

- Localização geográfica e caracterização física 
A segunda área de estudo (área B) localiza-se no Município de Iracemápolis, situada a, situada à $22^{\circ} 35^{\prime} \mathrm{S}$ de latitude e $47^{\circ} 31^{\prime} \mathrm{W}$ de longitude.

O estudo foi conduzido na área restaurada, de aproximadamente 20 ha, às margens da represa de abastecimento público municipal, fazendo parte da microbacia do Ribeirão Cachoeirinha (Anexo B). O plantio desta região foi realizado em 1987 apresentando, portanto, 14 anos de idade na época em que foi realizado o estudo.

A área é cercada por uma estrada de terra, de aproximadamente 2 metros de largura, que funciona como um aceiro entre ao plantio e a área do entorno, dominada por cultura de cana-de-açúcar. Nesta áreas é possível observar diferentes estratos e o dossel apresenta-se com aproximadamente $10 \mathrm{~m}$ de altura (levantamento realizado com 200 indivíduos).

O clima nesta região é do tipo Cwa na classificação de Köpen, com índice pluviométrico variando de 1.100 a $1.700 \mathrm{~mm}$ anuais. Foram encontrados na região 5 grupos de solo: Latossolo Roxo distrófico; Latossolo Vermelho Amarelo Húmico; Latossolo Roxo eutrófico; Terra Roxa Estruturada; Podzôlico Vermelho-Amarelo abruptico. O solo predominate na microbacia é o do grupo Latossolo Roxo distrófico.

- Caracterização do projeto de restauração

A microbacia do Ribeirão Cachoeirinha apresenta uma área aproximada de 1.500 ha, sendo 92,80\% desta ocupada por cultura de cana-de-açúcar; o restante está distribuído entre três represas, áreas ribeirinhas, mata natural, reflorestamento de eucalipto, pastagens, benfeitorias e cultura de milho. As consequências desta desproporcional ocupação e uso da terra que determinaram o depauperamento do reservatório público, motivaram o governo local a determinou desapropriação de uma faixa de $50 \mathrm{~m}$ de contorno dos reservatórios e de $30 \mathrm{~m}$ ao longo de todos os rios da microbacia. Após esta desapropriação foi feita a revegetação destas áreas.

Como a área revegetada historicamente era usada para o plantio de cana-deaçúcar, foi adotada, como prática de preparo de solo, duas gradeações pesadas, que impediram a rebrota da cana. Para a conservação do solo nas áreas de plantio, principalmente nas fases iniciais, foi construído no contorno do reservatório, um terraço numa faixa de largura de 50m e declividade de 1\%, com o objetivo de disciplinar e controlar as condições de escoamento superficial e de infiltração das águas pluviais 
A maioria dos indivíduos utilizados no plantio da área pertence a espécies arbóreas ocorrentes em remanescentes de formações florestais da região, tendo sido selecionada a partir de levantamentos florísticos e fitossiológicos destes remanescentes. Foram introduzidas ainda algumas espécies frutíferas, no intuito de atrair a fauna regional, facilitando com isso o fluxo de propágulos na área e algumas exóticas agressivas na faixa de bordadura, para amenizar os efeitos do cultivo da cana do entorno da área restaurada (Rodrigues et al., 1992) (Anexo C)

No plantio, as espécies foram combinadas em módulos baseados nos conceitos de sucessão secundária. Cada módulo continha 9 indivíduos, num espaçamento inicial de 4 × 4 metros e numa segunda fase do plantio 3 × 3 metros. Em cada módulo foram implantados 6 indivíduos de espécies pioneiras, 2 de secundárias iniciais, para 1 de secundária tardia ou climax. Foram utilizadas para a recuperação desta área 140 espécies apresentadas no Anexo A.

Em função da interferência causada pela flutuação do nível de água do reservatório, foram criadas duas diferentes sub-áreas: sub-área I, adjacente ao curso de água, numa faixa de $3 \mathrm{~m}$, onde foram introduzidas espécies típicas de condição ciliar, adaptadas a períodos variáveis de inundação do solo; e sub-área II que fica paralela a primeira, possuindo espécies típicas de floresta Estacional Mesófila Semidecídua, não sujeitas à encharcamento do solo.

\subsection{Metodologia}

\subsubsection{Zoneamento das áreas e desenho amostral}

Inicialmente, foi feito o reconhecimento das áreas onde foi desenvolvido o projeto de pesquisa, para então serem alocadas as parcelas.

Com esta finalidade, cada uma das áreas foi seccionada ao longo de sua maior extensão em segmentos unitários de $100 \mathrm{~m}$ de comprimento e largura variável de acordo com o próprio desenho da área, (compondo 10 segmentos na área $A$ e 32 na na área B). Foram instaladas estacas nas bordas destes segmentos delimitando suas áreas. O interior de cada um compartimentosdestes foi vistoriado, procurando-se identificar características fisionômicas e ambientais. Assim foram analisados os seguintes descritores: 
- distância mínima de posicionamentoem relação à borda equivalente a 10m.;

- condições parecidas de cobertura vegetal do trecho total a ser amostrado ;

- sem domínio de espécies invasoras herbáceas;

- ausência de clareiras;

- sem interferência antrópica;

- solo não sujeito à inundação;

- sem desnível topográfico.

Cada um dos segmentos foi então classificado de acordo com estas características em:

ambiente 1 - todas exigências atendidas;

ambiente 2 - poucas exigência não atendidas;

ambiente 3 - poucas exigências atendidas.

Como critério de alocação de parcelas foram priorizados aqueles segmentos que mais atendessem às condições acima especificadas.

Com base nestas informações, foram escolhidos os locais de instalação das parcelas. Em cada uma das áreas foram alocadas 10 parcelas amostrais de $10 \times 10 \mathrm{~m}$ totalizando uma área de 0,1 ha.

Segundo este critério de classificação ambiental adotado para os segmentos, verificou-se a seguinte distribuição:

$\mathrm{Na}$ área $\mathrm{A}$ seis parcela foram instaladas em ambientes classificados como $2 \mathrm{e}$ quatro parcelas foram localizadas em ambiente tipo 3.

Ná área B foram instaladas seis parcelas em ambiente 1, e as quatro parcelas restantes, em ambiente 2. Todas as parcelas desta área apresentam espaçamento $4 \times 4 \mathrm{~m}$.

\subsubsection{O banco de sementes}

Foram demarcadas, em cada uma das parcelas amostrais, 3 subparcelas de $0,5 \times 0,5 \mathrm{~m}$ alocadas de forma casualizada, totalizando 30 pontos em cada área. Estas subparcelas foram subdivididas em quatro quadrantes menores, de tamanho de $0,25 \mathrm{x}$ $0,25 \mathrm{~m}$.

Foram realizadas duas coletas do banco de sementes, sendo uma na estação chuvosa (fevereiro) e outra na estação seca (agosto) de 2001. Em cada estação, foi 
coletada uma amostra do solo e da serapilheira presentes em um dos quadrantes previamente estabelecido, evitando repetição.

Desta forma, foram coletados, em cada época de amostragem 30 amostras de $0,0625 \mathrm{~m}^{2}$ a uma profundidade de $0,05 \mathrm{~m}$ totalizando $1,875 \mathrm{~m}^{2}$ de área total amostrada, correspondendo a um volume de $0,003 \mathrm{~m}^{3}$ para cada uma das áreas estudadas

Para a coleta do solo foi feita uma escavação vertical, nas laterais do quadrante, facilitando com isso a medição da profundidade desejada. $O$ solo e a serapilheira foram coletados com o auxílio de uma espátula e todo o material foi acondicionado em saco plástico, devidamente identificado e transportado até o viveiro. Este procedimento seguiu o utilizado por Roizman (1993).

Posteriormente essas amostras foram postas para germinar, seguindo 0 modelo da maioria dos trabalhos envolvendo banco de sementes (Brown, 1992).

Assim, as amostras foram depositadas em bandejas, no viveiro do Departamento de Ciências Biológicas da Escola Superior de Agricultura "Luiz de Queiroz". No caso da serapilheira, os fragmentos maiores, como galhos e cascas de madeira, foram submetidos a um processo seletivo por triagem, a fim de evitar que as sementes fossem sombreadas. A restante do material foi depositada nas bandejas, juntamente com a amostra do solo da mesma região.

As bandejas ficaram expostas a altas intensidades de luz e temperatura, pois se assumiu que maioria das sementes presentes no banco, pertencem a espécies de estágio inicial e, portanto, fotoblásticas positiva (Grombone-Guarantini, 1999). As amostras colocadas nas bandejas foram revolvidas a cada dois meses com o objetivo de estimular a germinação das sementes.

Bandejas controle, contendo areia estéril, foram colocadas entre as amostras procurando identificar possíveis contaminação. As amostras foram irrigadas duas vezes ao dia, durante o verão e uma vez ao dia, durante o inverno.

O monitoramento das plântulas foi realizado assistematicamente. As plântulas emergentes foram identificadas, quantificadas, por contagem direta, e retiradas para não interferir na emergência de outras sementes. Após a emergência das plântulas, aguardou-se até que os indivíduos apresentassem as primeiras folhas cotiledonares, para só então serem eliminadas.

Os indivíduos de difícil identificação foram transplantados para sacos plásticos ou vasos para maior desenvolvimento e futura identificação botânica; ou ainda 
prensado, armazenado e posteriormente confirmados mediante consulta bibliográfica ou a exsicatas contidas no Herbário da Escola Superior de Agricultura "Luiz de Queiroz" (ESA).

Foram calculados os parâmetros fitossociológicos de densidade e frequência absoluta e relativa (Müeller-Dombois \& Ellenberg, 1974) e o índice de similaridade de Sorensen, das amostras obtidas em cada estação de coleta para cada área de estudo.

\subsection{Resultados}

\subsection{1 Área A}

No levantamento das sementes geminadas nas amostras do banco em uma área total de $1,875 \mathrm{~m}^{2}$ foram obtidos os seguintes valores:

- 616 indivíduos na estação chuvosa, dos quais 147 são espécies arbustivasarbóreas e 469 herbáceas; densidade média: 328,53 sementes. ${ }^{-2}$; média de indivíduos por parcela: 20,53 $( \pm 24,73)$.

- 461 indivíduos na estação seca sendo 54 destas espécies ábustivasarbóreas e 407 herbáceas; densidade média: 245,87 sementes. ${ }^{-2}$; média de indivíduos encontrada por parcela:15,37 $( \pm 14,10)$.

As tabelas 3 e 4 apresentam as relações das espécies e o número de indivíduos encontrados nas amostras do banco de sementes nas estações chuvosa e seca.

Verificou-se grande diferença no número de sementes por parcela. Os valores encontrados variaram entre 74,33 a menos de um indivíduo por parcela para a estação chuvosa, e entre 38,33 a menos de um indivíduo na estação seca.

Já o número de espécies por parcela variou de 12,33 a menos de uma espécie na estação chuvosa, e de 9,30 a menos de uma espécie na estação seca. A média de espécies por parcela na estação chuvosa foi de 4,69 $( \pm 3,65)$ e de $3,49( \pm 3,08)$ na segunda estação. 
Tabela 3. Relação das espécies, número total ( $\mathrm{N}^{\circ}$ Ind), média e desvio padrão e forma de vida dos indivíduos germinados nas amostras do banco de sementes, na área A (área de estudo em Piracicaba, SP) para o levantamento feito na estação chuvosa (fevereiro) de 2001.

\begin{tabular}{|c|c|c|c|c|c|}
\hline Família & Espécie & Autor & $\mathrm{N}^{\circ}$ Ind & $\begin{array}{c}\text { Média } \pm \\
\text { Desvio }\end{array}$ & $\begin{array}{c}\text { Forma de } \\
\text { vida }\end{array}$ \\
\hline Mimosaceae & Leucaena leucocephala & (Lam.) de Wit & 105 & $3,50 \pm 9,56$ & Árvore \\
\hline Euphorbiaceae & Croton urucurana & Baill. & 15 & $0,50 \pm 1,08$ & Árvore \\
\hline Tiliaceae & Muntingia calabura & L. & 9 & $0,30 \pm 0,95$ & Árvore \\
\hline Boraginaceae & Cordia myxa & L. & 9 & $0,30 \pm 0,64$ & Árvore \\
\hline Mimosaceae & Enterolobium contortisiliquum & (Vell.) Morong. & 7 & $0,20 \pm 0,74$ & Árvore \\
\hline Meliaceae & Melia azedarach & $\mathrm{L}$. & 1 & $0,03 \pm 0,10$ & Árvore \\
\hline Myrtaceae & Eugenia jambos & $\mathrm{L}$. & 1 & $0,03 \pm 0,10$ & Árvore \\
\hline Malvaceae & Sida sp2 & & 101 & $3,37 \pm 5,18$ & Erva \\
\hline Euphorbiaceae & Phyllanthus tenellus & Roxb. & 84 & $2,80 \pm 6,49$ & Erva \\
\hline Euphorbiaceae & Chamaesyce hirta & (L.) Millsp. & 79 & $2,63 \pm 4,89$ & Erva \\
\hline Malvaceae & Sida sp1 & & 45 & $1,50 \pm 1,91$ & Erva \\
\hline Asteraceae & Bidens pilosa & L. & 27 & $0,90 \pm 1,21$ & Evva \\
\hline Amaranthaceae & Alternanthera tenella & Colla & 19 & $0,63 \pm 1,06$ & Erva \\
\hline Poaceae & Eusine indica & (L.) Gaertn. & 16 & $0,10 \pm 0,32$ & Eva \\
\hline Portulacaceae & Portulaca oleracea & L. & 16 & $0,53 \pm 1,15$ & Enva \\
\hline Asteraceae & Parthenium husterophorus & L. & 11 & $0,37 \pm 1,05$ & Erva \\
\hline Poaceae & Paspalum notatum & DC. & 9 & $0,30 \pm 0,62$ & Enva \\
\hline Labiateae & Hyptis lophanta & Mart.ex Benth & 8 & $0,27 \pm 0,58$ & Erva \\
\hline Poaceae & Eragrostis piloso & (L.) P. Beauv. & 8 & $0,27 \pm 0,62$ & Erva \\
\hline Solanaceae & Solanum americanum & Mill. & 7 & $0,23 \pm 0,39$ & Erva \\
\hline Amaranthaceae & Amaranthus retroflexus & L. & 7 & $0,23 \pm 0,35$ & Erva \\
\hline Asteraceae & Emilia sonchifolia & (L.) D.C. & 6 & $0,20 \pm 0,36$ & Erva \\
\hline Poaceae & Panicum maximum & Jacq. & 4 & $0,13 \pm 0,28$ & Evva \\
\hline Asteraceae & Gnaphalium spicatum & Lam. & 3 & $0,10 \pm 0,32$ & Erva \\
\hline Cruciferae & Lepidium virginicum & L. & 3 & $0,10 \pm 0,31$ & Eva \\
\hline Rubiaceae & Richardia brasiliensis & Gomes & 3 & $0,10 \pm 0,22$ & Erva \\
\hline Oxslidaceae & Oxalis corniculata & $\mathrm{L}$. & 2 & $0,07 \pm 0,21$ & Eva \\
\hline Papilionoideae & Indigofera anil & L. & 2 & $0,07 \pm 0,14$ & Erva \\
\hline Euphorbiaceae & Euphorbia heterofila & L. & 1 & $0,53 \pm 0,47$ & Eva \\
\hline Convovulaceae & Dichondria microcalyx & (Hallier f.) Fabris & 1 & $0,03 \pm 0,10$ & Erva \\
\hline Papilionoideae & Indigofera hirsuta & L. & 1 & $0,03 \pm 0,10$ & Eva \\
\hline Comeliaceae & Comelina bengalensis & & 1 & $0,03 \pm 0,10$ & Erva \\
\hline Bignoniaceae & Cleome affinis & DC. & 1 & $0,03 \pm 0,10$ & Evva \\
\hline desconhecidos & Chenopodium ambrosoides & L. & 1 & $0,03 \pm 0,10$ & Erva \\
\hline Malvaceae & Sida sp3 & & 1 & $0,03 \pm 0,10$ & Eva \\
\hline Amaranthaceae & Amaranthus viridis & L. & 1 & $0,03 \pm 0,10$ & Erva \\
\hline Solanaceae & Solanum sisymbrifolium & Lam. & 1 & $0,03 \pm 0,10$ & Erva \\
\hline
\end{tabular}


Tabela 4. Relação das espécies, número total ( $\mathrm{N}^{\circ}$ Ind), média e desvio padrão e forma de vida dos indivíduos germinados nas amostras do banco de sementes na área A (área de estudo em Piracicaba, SP) para o levantamento feito na estação seca (agosto) de 2001.

\begin{tabular}{|c|c|c|c|c|c|}
\hline Família & Espécie & Autor & $\mathrm{N}^{\circ}$ Ind & $\begin{array}{l}\text { Média } \pm \\
\text { Desvio }\end{array}$ & $\begin{array}{c}\text { Forma de } \\
\text { vida }\end{array}$ \\
\hline Mimosaceae & Leucaena leucocephala & (Lam.) de Wit & 33 & $1,10 \pm 2,09$ & Árvore \\
\hline Boraginaceae & Cordia myxa & $\mathrm{L}$. & 21 & $0,70 \pm 1,08$ & Árvore \\
\hline Labiateae & Hyptis lophanta & Mart. ex Benth & 112 & $3,73 \pm 4,36$ & Eva \\
\hline Euphorbiaceae & Phyllanthus tenellus & Roxb. & 93 & $3,10 \pm 4,05$ & Eva \\
\hline Amaranthaceae & Amaranthus retroflexus & L. & 40 & $1,33 \pm 2,70$ & Eva \\
\hline Portulacaceae & Portulaca oleracea & L. & 29 & $0,97 \pm 1,32$ & Eva \\
\hline Cruciferae & Lepidium virginicum & L. & 28 & $0,93 \pm 2,95$ & Eva \\
\hline Euphorbiaceae & Chamaesyce hirta & (L.) Millsp. & 23 & $0,77 \pm 1,97$ & Eva \\
\hline Solanaceae & Solanum americanum & Mill. & 16 & $0,53 \pm 0,85$ & Eva \\
\hline Poaceae & Setaria geniculata & P. Beauv. & 12 & $0,40 \pm 0,58$ & Eva \\
\hline Rubiaceae & Richardia brasiliensis & Gomes & 10 & $0,33 \pm 0,85$ & Eva \\
\hline Poaceae & Eragrostis piloso & (L.) P. Beauv. & 5 & $0,17 \pm 0,32$ & Eva \\
\hline Asteraceae & Emilia sonchifolia & (L.) D.C. & 5 & $0,17 \pm 0,24$ & Enva \\
\hline Asteraceae & Parthenium & L. & 5 & $0,17 \pm 0,42$ & Eva \\
\hline Solanaceae & Physalis angulata & L. & 5 & $0,17 \pm 0,53$ & Erva \\
\hline Papilionoideae & Indigofera hirsuta & L. & 4 & $0,13 \pm 0,42$ & Erva \\
\hline Malvaceae & Sida sp2 & & 3 & $0,10 \pm 0,22$ & Eva \\
\hline desconhecidos & Coronopus didimus & (L.) Sm. & 3 & $0,10 \pm 0,30$ & Eva \\
\hline Umbeliferae & Apium leptophyllum & F.Muell. ex & 3 & $0,10 \pm 0,22$ & Erva \\
\hline Malvaceae & Sida sp3 & & 2 & $0,07 \pm 0,21$ & Erva \\
\hline Asteraceae & Ageratum conyzoides & L. & 2 & $0,07 \pm 0,14$ & Eva \\
\hline Malvaceae & Sida sp1 & & 2 & $0,07 \pm 0,21$ & Erva \\
\hline Portulacaceae & Talinum paniculatum & Mill. & 1 & $0,03 \pm 0,10$ & Eva \\
\hline Asteraceae & Bidens pilosa & $\mathrm{L}$. & 1 & $0,03 \pm 0,10$ & Eva \\
\hline Amaranthaceae & Amaranthus viridis & L. & 1 & $0,03 \pm 0,10$ & Eva \\
\hline Amaranthaceae & Alternanthera tenella & Colla & 1 & $0,03 \pm 0,10$ & Erva \\
\hline Asteraceae & Eclipta alba & (L.) Hassk. & 1 & $0,03 \pm 0,10$ & Enva \\
\hline
\end{tabular}

Não foram observadas diferenças significativas entre as duas estações de coleta em relação ao número de indivíduos, conforme pode ser avaliado na Figura 3. 


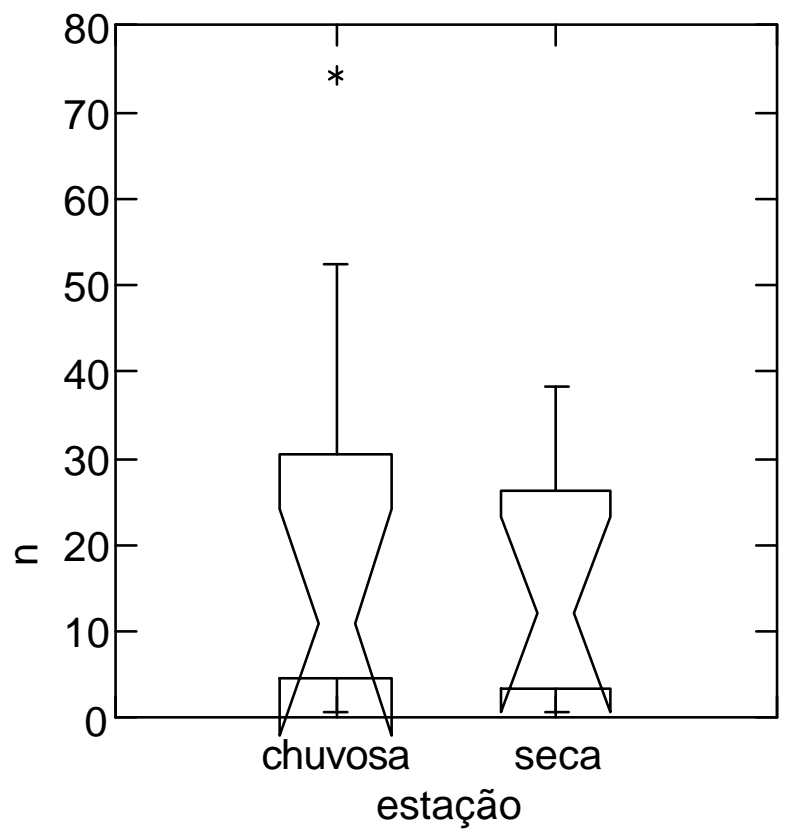

Figura 3 - Comparação do número de sementes germinado nas amostras do banco na estação chuvosa (fevereiro de 2001) e na seca (agosto de 2001) na a área A (área de estudo em Piracicaba, SP). Nota explicativa: cada caixa ("box") representa $50 \%$ das observações; as barras verticais inferiores e superiores representam a amplitude total da distribuição (25\% e $75 \%$ ), exceto os valores extremos $\left({ }^{*}\right)$ e os muito extremos $\left({ }^{\circ}\right)$ ("outliers"). A linha horizontal dentro da caixa representa a mediana, e os limites de confiança de $95 \%$ são representados pelas linhas indentadas ao redor da mediana.

Agrupando os indivíduos por forma de vida, verifica-se que há uma maior porcentagem de indivíduos herbáceos que arbustivo-arbóreos (Figura 4). A densidade de sementes arbustivas-arbórea encontrada foi de 78,40 sementes. $\mathrm{m}^{-2}$ na estação chuvosa e 28,80 sementes. $\mathrm{m}^{-2}$ na estação seca. Para as herbáceas, a densidade obtida foi de 250,13 e 217,07 sementes. $\mathrm{m}^{-2}$, respectivamante, nestas estações. 


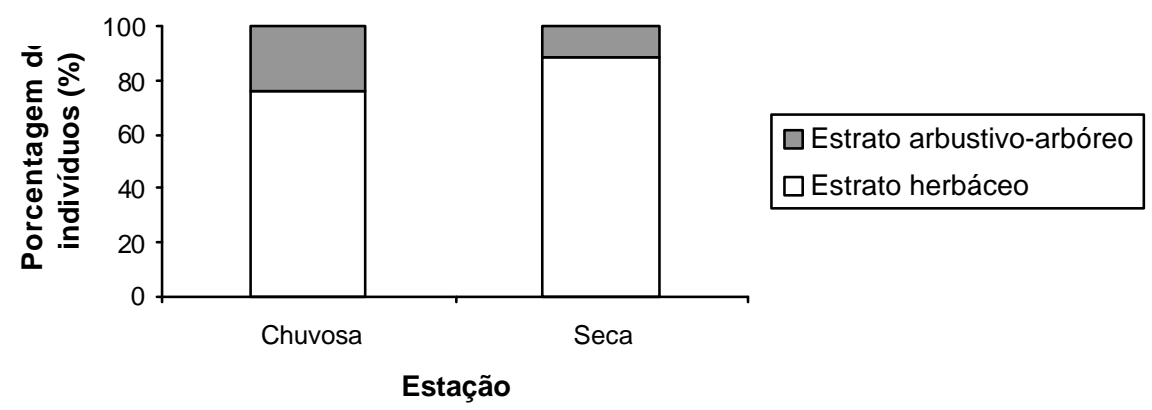

Figura 4 - Porcentagem de indivíduos germinados nas amostras do banco de sementes agrupados por forma de vida na área A (área de estudo em Piracicaba) em duas estações de coleta, seca (agosto) e chuvosa (fevereiro) de 2001.

Foram identificadas 37 espécies na estação chuvosa, e 27 na estação seca. A maior parte das espécies encontrada é caracterizada como herbácea, correspondendo a 81,08\% (30 espécies) na estação chuvosa e 92,59\% (25 espécies) na estação seca. As espécies arbustivas-arbóreas representam 18,92\% (7 espécies) na estação chuvosa e 7,41\% (2 espécies) na estação seca.

As espécies arbustivas-arbóreas foram agupadas de acordo com sua classificação sucessional e na Tabela 5 estão apresentadas as porcentagens de indivíduos e espécies para cada um destes grupos.

Tabela 5. Porcentagem dos indivíduos e espécies arbustivos-arbóreos germinados nas amostras do banco de sementes, agrupados por grupo ecológico, nas estação chuvosa (fevereiro de 2001) e seca (agosto de 2001) para a área $A$, área de estudo em Piracicaba, SP.

\begin{tabular}{lcccc}
\hline Grupo Ecológico & \multicolumn{2}{c}{ Estação chuvosa } & \multicolumn{2}{c}{ Estação seca } \\
& Indivíduos (\%) & Espécies (\%) & Indivíduos (\%) & Espécies (\%) \\
\hline Exóticas & 78,23 & 42,86 & 61,11 & 50,00 \\
Pioneiras & 10,20 & 14,28 & 0,00 & 0,00 \\
Secundárias Iniciais & 10,88 & 28,57 & 38,89 & 50,00 \\
Frutífera & 0,68 & 14,28 & 0,00 & 0,00 \\
\hline
\end{tabular}


Leucena leucocepha foi a espécies arbórea que apresentou os mais elevados valores para freqüência absoluta (36,67\% e 30,00\%), freqüência relativa $(44,00 \%$ e $50,00 \%)$, densidade absoluta $\left(0,05\right.$ ind. $\mathrm{m}^{-2}$ e 0,02 ind. $\left.\mathrm{m}^{-2}\right)$ e relativa $(70,71 \%$ e $58,00 \%$ ). Os valores entre parênteses representam respectivamante as porcentagens das variáveis analisadas para as estações chuvosa e seca. Na estação seca, no entanto, estes valores pouco diferem dos encontrados para Cordia myxa, a outra espécie arbórea presente nas amostras

A Tabela 6 compara o efeito sazonal na variação dos resultados obtidos para os parâmetros fitissociológicos analisados para cada estação de coleta.

Tabela 6. Parâmetros fitossociológicos (freqüência absoluta - Fa; freqüência relativa Fr; densidade absoluta - Da; densidade relativa - Dr) dos indivíduos germinados nas amostras do banco de sementes na Área A (área de estudo em Piracicaba) para duas estações de coleta (chuvosa- fevereiro e secaagosto de 2001).

\begin{tabular}{|c|c|c|c|c|c|c|}
\hline Espéice & Classificação & $\mathrm{Fa}(\%)$ & $\operatorname{Fr}(\%)$ & $\mathrm{Da}$ (ind. $\mathrm{m}^{-2}$ ) & $\operatorname{Dr}(\%)$ & Estação \\
\hline $\begin{array}{l}\text { Leucaena leucocephala } \\
\text { (Lam.) de Wit }\end{array}$ & Exótica & 36,67 & 44,00 & 0,0528 & 70,71 & $\overline{\text { Chuvosa }}$ \\
\hline Lordia myxa & Secundária Inicial & 16,67 & 20,00 & 0,0043 & 5,71 & Chuvosa \\
\hline $\begin{array}{l}\text { Croton urucurana } \\
\text { Baill. }\end{array}$ & Pioneira & 13,33 & 16,00 & 0,0080 & 10,71 & Chuvosa \\
\hline $\begin{array}{l}\text { Enterolobium contortisiliquum } \\
\text { (Vell.) Morong. }\end{array}$ & Secundária Inicial & 6,67 & 8,00 & 0,0037 & 5,00 & Chuvosa \\
\hline $\begin{array}{l}\text { Muntingia calabura } \\
\text { L. }\end{array}$ & Exótica & 3,33 & 4,00 & 0,0048 & 6,43 & Chuvosa \\
\hline $\begin{array}{l}\text { Melia azedarach } \\
\text { L. }\end{array}$ & Exótica & 3,33 & 4,00 & 0,0005 & 0,71 & Chuvosa \\
\hline $\begin{array}{l}\text { Eugenia jambos } \\
\text { L. }\end{array}$ & Frutífera & 3,33 & 4,00 & 0,0005 & 0,71 & Chuvosa \\
\hline $\begin{array}{l}\text { Leucaena leucocephala } \\
\text { (Lam.) de Wit }\end{array}$ & Exótica & 30,00 & 50,00 & 0,0155 & 58,00 & Seca \\
\hline $\begin{array}{l}\text { Cordia myxa } \\
\text { L. }\end{array}$ & Secundária Inicial & 30,00 & 50,00 & 0,0112 & 42,00 & Seca \\
\hline
\end{tabular}


O índice similaridade de Sorensen na estação chuvosa, de 3,77\%, demonstrou a baixa similaridade entre a flora implantada no projeto de restauração e as espécies provenientes do banco de sementes. Não houve similaridade entre os indivíduos germinados no banco e a flora implantada na estação seca. Este mesmo índice obtido para todo o período de estudo foi de 3,39\%.

A única espécie comum ao banco de sementes da estação chuvosa e à flora implantada no projeto de restauração foi Croton urucurana.

As espécies exclusivas ao banco de sementes na estação chuvosa foram Leucaena leucocephala, Mutingia calabura, Cordia myxa, Enterolobium contortisiliquum, Melia azadarach, Eugenia jambos. Na estação seca as duas espécies encontradas, Leucaena leucocephala e Cordia Myxa, são exclusivas ao banco.

Leucaena leucocephala e Cordia Myxa estiveram presentes no banco de sementes na duas épocas de amostragem.

O desenvolvimento das sementes foi observado durante seis meses consecutivos, sendo que após o primeiro houve uma queda na porcentagem de germinação, permanecendo constante durante os seguintes (Figura 5).

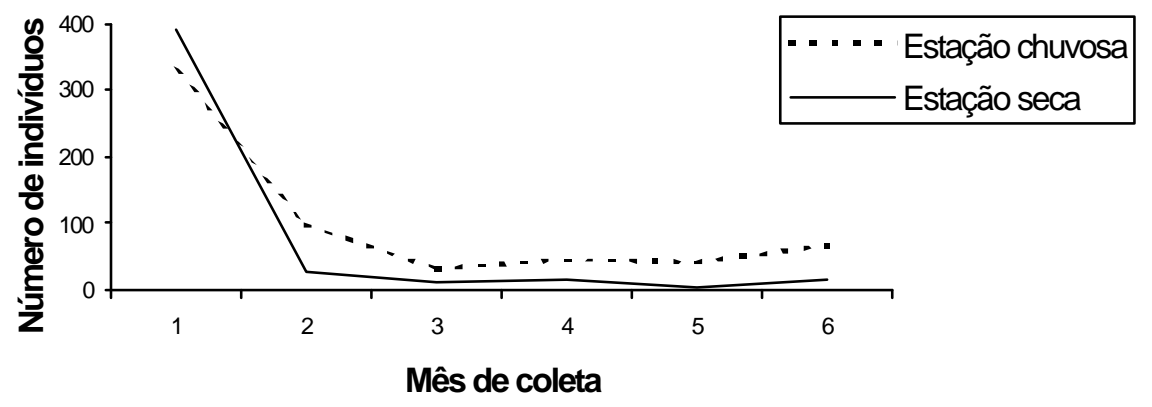

Figura 5 - Número de indivíduos germinados nas amostras do banco de sementes nos meses de fevereiro a julho de 2001 na área A (área de estudo em Piraicaba, $\mathrm{SP})$. 


\subsection{2 Área B}

O número total de indivíduos observado no levantamento das sementes germinadas no banco, para as diferentes estações de coleta, em uma área total de $1,875 \mathrm{~m}^{2}$ apresentou a seguinte distribuição:

- 2122 indivíduos na estação chuvosa, divididos entre 333 espécies arbustivas-arbóreas e 1789 herbáceas; densidade média: 1.131,73 sementes. $m^{-2}$; média de indivíduos por parcela: 70,73 $( \pm 55,84)$.

- 1285 indivíduos na estação seca, entre 284 espécies arbustivas-arbóreas e 1001 espécies herbáceas; densidade média: 685,30 sementes. $\mathrm{m}^{-2}$; média de indivíduos por parcela: $42,87( \pm 27,36)$.

As Tabelas 7 e 8 apresentam as relações das espécies e o número de indivíduos encontrados nas amostras do banco de sementes nas estações chuvosa e seca para esta área.

A análise do número de indivíduos demonstra alta heterogenidade espacial no banco de semente. O número de sementes germinados nas amostras do banco variou de 177,67 a 4,30 indivíduos por parcela, na estação chuvosa. Na estação seca os valores apresentaram intervalo menor de variação, ficando entre 100 a 10 indivíduos por parcela.

O número de espécies por parcela variou de 12,00 a 2,60 na estação chuvosa e na estação seca de 7,00 a 3,30. A média de espécies obtida foi de 6,12 $( \pm 3,06)$ na estação chuvosa e de 4,93 $( \pm 1,38)$ na estação seca.

O número de indivíduos encontrado na estação chuvoso não diferiu estatisticamente daquele encontrado na estação seca, como pode ser visto na Figura 6.

Considerando a forma de vida dos indivíduos germinados nas amostras do banco, novamente é possível verificar a dominância de indivíduos herbáceos sobre os demais (Figura 7). A densidade de sementes arbustivas-arbóreas encontrada foi de 177,60 sementes. $\mathrm{m}^{-2}$ para a estação chuvosa e 151,47 sementes. $\mathrm{m}^{-2}$ na estação seca. As espécies herbáceas apresentaram valores de densidade igual a 954,13 sementes. $\mathrm{m}^{-2}$ na estação chuvosa e 533,33 sementes. $\mathrm{m}^{-2}$ na estação seca. 
Tabela 7. Relação das espécies, número total ( $\mathrm{N}^{\circ}$ Ind), média e desvio padrão e forma de vida dos indivíduos germinados nas amostras do banco de sementes, na área B (área de estudo em Iracemápolis, SP) para o levantamento feito na estação chuvosa (fevereiro) de 2001.

\begin{tabular}{|c|c|c|c|c|c|}
\hline Família & Espécie & Autor & $\mathrm{N}^{\circ}$ Ind & $\begin{array}{c}\text { Média } \pm \text { Desvio } \\
\text { Padrão }\end{array}$ & $\begin{array}{l}\text { Forma } \\
\text { de vida }\end{array}$ \\
\hline Meliaceae & Melia azedarach & L. & 273 & $9,10 \pm 20,26$ & Árvore \\
\hline Mimosaceae & Leucaena leucocephala & (Lam.) de Wit & 46 & $1,53 \pm 3,71$ & Árvore \\
\hline Boraginaceae & Cordia myxa & L. & 6 & $0,20 \pm 0,53$ & Árvore \\
\hline Euphorbiaceae & Croton floribundus & (L.) Spreng. & 4 & $0,13 \pm 0,42$ & Árvore \\
\hline Euphorbiaceae & Croton urucurana & Baill. & 2 & $0,07 \pm 0,21$ & Árvore \\
\hline Tiliaceae & Muntingia calabura & L. & 1 & $0,03 \pm 0,10$ & Árvore \\
\hline Sterculiaceae & Helicteres ovata & Lam. & 1 & $0,03 \pm 0,10$ & Árvore \\
\hline Portulacaceae & Portulaca oleracea & L. & 925 & $30,83 \pm 43,95$ & Erva \\
\hline Poaceae & Eragrostis piloso & (L.) P. Beauv. & 459 & $15,30 \pm 18,51$ & Erva \\
\hline Euphorbiaceae & Phyllanthus tenellus & Roxb. & 81 & $2,70 \pm 3,57$ & Erva \\
\hline Poaceae & Panicum maximum & Jacq. & 73 & $2,43 \pm 5,71$ & Erva \\
\hline Amaranthaceae & Amaranthus retroflexus & L. & 66 & $2,20 \pm 2,30$ & Erva \\
\hline Papilionoideae & Indigofera anil & L. & 51 & $1,70 \pm 3,07$ & Erva \\
\hline Malvaceae & Sida sp1 & & 21 & $0,70 \pm 0,85$ & Erva \\
\hline Poaceae & Paspalum notatum & DC. & 21 & $0,70 \pm 0,92$ & Erva \\
\hline Solanaceae & Solanum americanum & Mill. & 15 & $0,50 \pm 0,77$ & Erva \\
\hline Euphorbiaceae & Chamaesyce hirta & (L.) Millsp. & 7 & $0,23 \pm 0,35$ & Erva \\
\hline Poaceae & Eusine indica & (L.) Gaertn. & 7 & $0,23 \pm 0,45$ & Erva \\
\hline Papilionoideae & Indigofera hirsuta & L. & 7 & $0,23 \pm 0,45$ & Erva \\
\hline desconhecidos & Coronopus didimus & (L.) Sm. & 6 & $0,20 \pm 0,63$ & Erva \\
\hline desconhecidos & Conyzia bonaris & (L.) Cronquist & 6 & $0,20 \pm 0,45$ & Erva \\
\hline Poaceae & Brachiaria decumbens & Stapt. & 5 & $0,17 \pm 0,53$ & Erva \\
\hline Solanaceae & Physalis angulata & L. & 4 & $0,13 \pm 0,42$ & Erva \\
\hline Solanaceae & Solanum sisymbrifolium & Lam. & 4 & $0,13 \pm 0,23$ & Erva \\
\hline Bignoniaceae & Cleome affinis & DC. & 4 & $0,13 \pm 0,32$ & Erva \\
\hline Asteraceae & Emilia sonchifolia & (L.) D.C. & 4 & $0,13 \pm 0,17$ & Erva \\
\hline desconhecidos & Chenopodium ambrosoides & L. & 3 & $0,10 \pm 0,22$ & Erva \\
\hline Malvaceae & Sida sp3 & & 3 & $0,10 \pm 0,22$ & Erva \\
\hline Euphorbiaceae & Euphorbia heterofila & L. & 3 & $0,10 \pm 0,32$ & Erva \\
\hline Asteraceae & Bidens pilosa & L. & 2 & $0,07 \pm 0,14$ & Erva \\
\hline Convolvulaceae & Dichondra microcalyx & (Hallier f.) Fabris & 2 & $0,07 \pm 0,14$ & Erva \\
\hline Asteraceae & Ageratum conyzoides & L. & 2 & $0,07 \pm 0,21$ & Erva \\
\hline Malvaceae & Sida sp2 & & 2 & $0,07 \pm 0,21$ & Erva \\
\hline Papilionoideae & Crotalaria incana & L. & 1 & $0,03 \pm 0,10$ & Eva \\
\hline Asteracea & Eclipta alba & (L.) Hassk. & 1 & $0,03 \pm 0,10$ & Erva \\
\hline Oxalidaceae & Oxalis corniculata & L. & 1 & $0,03 \pm 0,10$ & Erva \\
\hline Portulacaceae & Talinum paniculatum & Gaertn. & 1 & $0,03 \pm 0,10$ & Erva \\
\hline Asteraceae & Sonchus oleraceus & & 1 & $0,03 \pm 0,10$ & Erva \\
\hline Papilionoideae & Desmodium tortuoso & (SW.) DC. & 1 & $0,03 \pm 0,10$ & Erva \\
\hline
\end{tabular}


Tabela 8. Relação das espécies, número total ( $\mathrm{N}^{\circ}$ Ind), média e desvio padrão e forma de vida dos indivíduos germinados nas amostras do banco de sementes, na área B ( área de estudo em Iracemápolis, SP) para o levantamento feito na estação seca (agosto) de 2001.

\begin{tabular}{|c|c|c|c|c|c|}
\hline Família & Espécie & Autor & $\mathrm{N}^{\circ}$ Ind & $\begin{array}{c}\text { Media } \pm \text { Desvio } \\
\text { padrão }\end{array}$ & $\begin{array}{l}\text { Forma } \\
\text { de vida }\end{array}$ \\
\hline Meliaceae & Melia azedarach & L. & 199 & $6,63 \pm 12,46$ & Arvore \\
\hline Mimosaceae & Leucaena leucocephala & (Lam.) de Wit & 59 & $1,97 \pm 5,02$ & Árvore \\
\hline Boraginaceae & Cordia myха & L. & 26 & $0,87 \pm 1,51$ & Árvore \\
\hline Poaceae & Eragrostis piloso & (L.) P. Beauv. & 509 & $18,63 \pm 19,91$ & Erva \\
\hline Portulacaceae & Portulaca oleracea & L. & 211 & $7,03 \pm 6,94$ & Erva \\
\hline Euphorbiaceae & Phyllanthus tenellus & Roxb. & 113 & $3,37 \pm 5,30$ & Erva \\
\hline Amaranthaceae & Amaranthus retroflexus & L. & 68 & $2,27 \pm 1,79$ & Erva \\
\hline Papilionoideae & Indigofera hirsuta & L. & 29 & $0,97 \pm 2,16$ & Erva \\
\hline Solanaceae & Solanum americanum & Mill. & 11 & $0,37 \pm 0,55$ & Erva \\
\hline Poaceae & Eusine indica & (L.) Gaertn. & 10 & $0,33 \pm 0,54$ & Eva \\
\hline Poaceae & Setaria geniculata & P. Beauv. & 9 & $0,30 \pm 0.42$ & Eva \\
\hline Poaceae & Digitaria sanguinalis & (L.) Scop. & 9 & $0,30 \pm 0,84$ & Erva \\
\hline Asteraceae & Gnaphalium spicatum & Lam. & 5 & $0,17 \pm 0,42$ & Erva \\
\hline Solanaceae & Physalis angulata & L. & 5 & $0,17 \pm 0,32$ & Erva \\
\hline desconhecidos & Conyzia bonaris & (L.) Cronquist & 4 & $0,13 \pm 0,32$ & Erva \\
\hline Asteraceae & Emilia sonchifolia & (L.) D.C. & 4 & $0,13 \pm 0,23$ & Erva \\
\hline desconhecidos & Coronopus didimus & (L.) Sm. & 3 & $0,10 \pm 0,30$ & Erva \\
\hline Bignoniaceae & Cleome affinis & DC. & 3 & $0,10 \pm 0,16$ & Erva \\
\hline Poaceae & Paspalum notatum & DC. & 2 & $0,06 \pm 0,21$ & Erva \\
\hline Convolvulaceae & Dichondra microcalyx & (Hallier f.) Fabris & 2 & $0,07 \pm 0,14$ & Erva \\
\hline Amaranthaceae & Amaranthus viridis & L. & 2 & $0,07 \pm 0,14$ & Erva \\
\hline Poaceae & Panicum maximum & Jacq. & 1 & $0,03 \pm 0,10$ & Erva \\
\hline Papilionoideae & Crotalaria incana & L. & 1 & $0,03 \pm 0,10$ & Erva \\
\hline
\end{tabular}

Foram identificadas 39 espécies na estação chuvosa, e 23 na estação seca. Novamente, a maior parte das espécies encontrada foi caracterizada como herbácea, correspondendo a 82,05 \% (32 espécies) na estação chuvosa e 86,96 \% (20 espécies) na estação seca. As espécies arbustivas-arbóreas representam 17,95 \% (7 espécies) na estação chuvosa e 13,04 \% (3 espécies) na estação seca. 


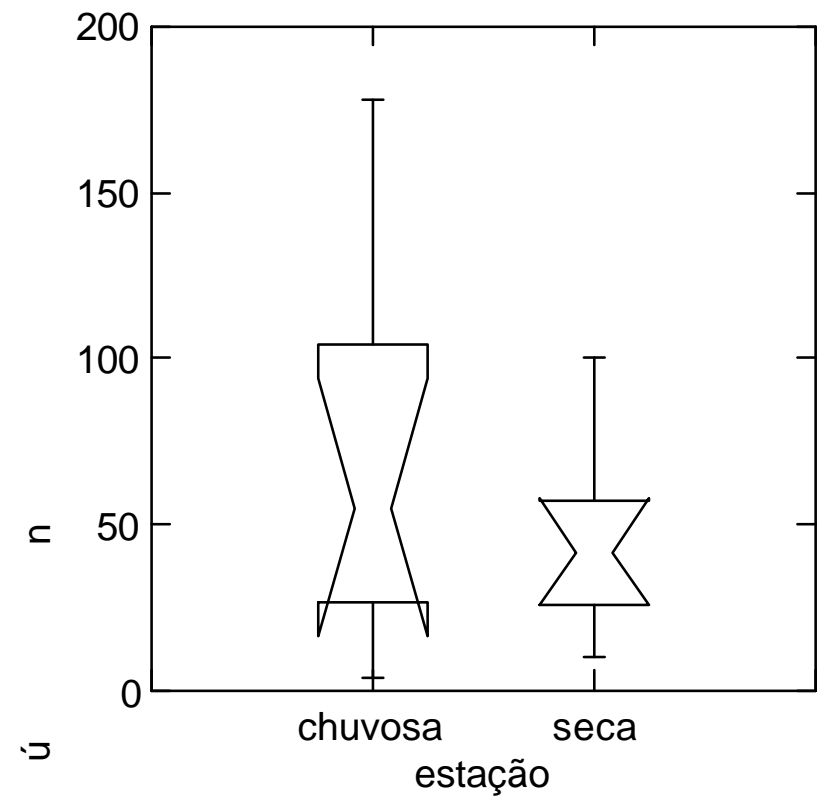

Figura 6 - Comparaça do número de sementes germinado nas amostras do banco na estação chuvosa (fevereiro de 2001) e na seca (agosto de 2001) para a área B (área de estudo em Iracemápolis, SP). Nota explicativa: cada caixa ("box") representa $50 \%$ das observações; as barras verticais inferiores e superiores representam a amplitude total da distribuição (25\% e $75 \%$ ), exceto os valores extremos $\left({ }^{*}\right)$ e os muito extremos $\left({ }^{\circ}\right)$ ("outliers"). A linha horizontal dentro da caixa representa a mediana, e os limites de confiança de $95 \%$ são representados pelas linhas indentadas ao redor da mediana.

As espécies ${ }^{\circ}$ arbustivas-arbóreas foram agrupadas de acordo com sua classificação sucessional e na Tabela 9 estão apresentadas as porcentagens de indivíduos e espécies, para cada um destes grupos. 


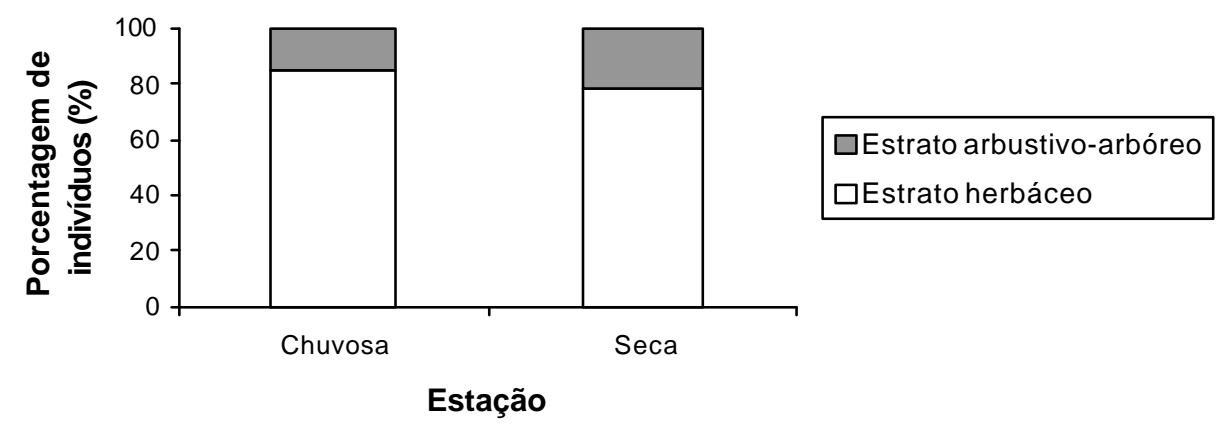

Figura 7 - Porcentagem de indivíduos germinados nas amostras do banco de sementes agrupados por forma de vida na área B (área de estudo em Iracemápolis), em duas estações de coleta, seca (agosto) e chuvosa (fevereiro) de 2001.

Tabela 9. Porcentagem dos indivíduos e espécies observadas nas amostras do banco de sementes agrupados por grupo ecológico, nas estação chuvosa (fevereiro de 2001) e seca (agosto de 2001) para a área B, área de estudo em Iracemápolis, SP.

\begin{tabular}{lcccc}
\hline Grupo Ecológico & $\begin{array}{c}\text { Estação chuvosa } \\
\text { Indivíduos (\%) }\end{array}$ & Espécies (\%) & $\begin{array}{c}\text { Estação seca } \\
\text { Indivíduos (\%) }\end{array}$ & Espécies (\%) \\
\hline Exóticas & 96,39 & 57,14 & 90,85 & 66,67 \\
Pioneiras & 1,80 & 28,57 & 0,00 & 0,00 \\
Secundárias Iniciais & 1,80 & 14,28 & 9,15 & 33,33 \\
\hline
\end{tabular}

Dentre as espécies arbustivas-arbóres encontradas, Melia azadarach foi a que apresentou os mais elevados valores para freqüência absoluta $(25,67 \%)$, freqüência relativa $(38,10 \%)$, densidade absoluta $\left(0,14\right.$ ind. $\left.\mathrm{m}^{-2}\right)$ e relativa $(72,89 \%)$ na estação chuvosa. Esta espécie obteve ainda os valores mais elevados na estação seca para freqüência absoluta $(33,33 \%)$, freqüência relativa $(38,46 \%)$, densidade absoluta $(0,11$ ind. $\mathrm{m}^{-2}$ ) e relativa $(72,89 \%)$ (Tabela 10$)$. 
Tabela 10. Parâmetros fitossociológicos (freqüência absoluta - Fa; freqüência relativa Fr; densidade absoluta - Da; densidade relativa - Dr) dos indivíduos germinados nas amostras do banco de sementes na área B (área de estudo em Iracemápolis) para duas estações de coleta (chuvosa - fevereiro e seca - agosto).

\begin{tabular}{|c|c|c|c|c|c|c|}
\hline Espécie & Classificação & $\mathrm{Fa}(\%)$ & $\operatorname{Fr}(\%)$ & $\begin{array}{c}\text { Da } \\
\text { (Ind. } \mathrm{m}^{-2} \text { ) }\end{array}$ & $\operatorname{Dr}(\%)$ & Estação \\
\hline $\begin{array}{l}\text { Melia azedarach } \\
\text { L. }\end{array}$ & Exótica & 26,67 & 38,10 & 0,1429 & 82,46 & Chuvosa \\
\hline $\begin{array}{l}\text { Leucaena leucocephala } \\
\text { (Lam.) de Wit }\end{array}$ & Exótica & 23,33 & 33,33 & 0,0240 & 13,85 & Chuvosa \\
\hline $\begin{array}{l}\text { Cordia myxa } \\
\text { L. }\end{array}$ & Secundária Inicial & 6,67 & 9,52 & 0,0021 & 1,23 & Chuvosa \\
\hline Croton floribundus & Pioneira & 3,33 & 4,76 & 0,0021 & 1,23 & Chuvosa \\
\hline $\begin{array}{l}\text { Croton urucurana } \\
\text { Baill. }\end{array}$ & Pioneira & 3,33 & 4,76 & 0,0010 & 0,62 & Chuvosa \\
\hline $\begin{array}{l}\text { Muntingia calabura } \\
\text { L. }\end{array}$ & Exótica & 3,33 & 4,76 & 0,0005 & 0,31 & Chuvosa \\
\hline $\begin{array}{l}\text { Helicteres ovata } \\
\text { Lam. }\end{array}$ & Exótica & 3,33 & 4,76 & 0,0005 & 0,31 & Chuvosa \\
\hline $\begin{array}{l}\text { Melia azedarach } \\
\text { L. }\end{array}$ & Exótica & 33,33 & 38,46 & 0,1061 & 70,82 & Seca \\
\hline $\begin{array}{l}\text { Leucaena leucocephala } \\
\text { (Lam.) de Wit }\end{array}$ & Exótica & 26,67 & 30,77 & 0,0299 & 19,93 & Seca \\
\hline Cordia myxa & Secundária Inicial & 26,67 & 30,77 & 0,0138 & 9,25 & Seca \\
\hline
\end{tabular}

Melia azadarah, Croton floribundus e Cordia myxa são espécies comuns ao banco de sementes da estação chuvosa e à flora implantada no projeto de restauração. Melia azadarah e Cordia myxa são espécies comuns também na estação seca.

As espécies exclusivas ao banco são Leucaena leucocephala, Croton urucurana, Mutingia calabura e Helicteris ovata na estação chuvosa e apenas $L$. leucocephala na estação seca. 
O índice similaridade de Sorensen demonstrou, também nesta área, baixa similaridade entre a flora implantada no projeto de restauração e as espécies provenientes do banco de sementes: $3,68 \%$ para estação chuvosa e 2,70\% para estação seca. No total das sementes germinadas no período de um ano foi encontrado um índice de similaridade de 3,50\%. Melia azadarah, Leucaena Leucocephala e Cordia myxa estiveram presentes no banco de sementes nas duas épocas de amostragem.

A maioria das espécies encontrada no banco de sementes germinou durante 0 primeiro mês, demonstrando a dominância por espécies características de áreas abertas (Figura 8).

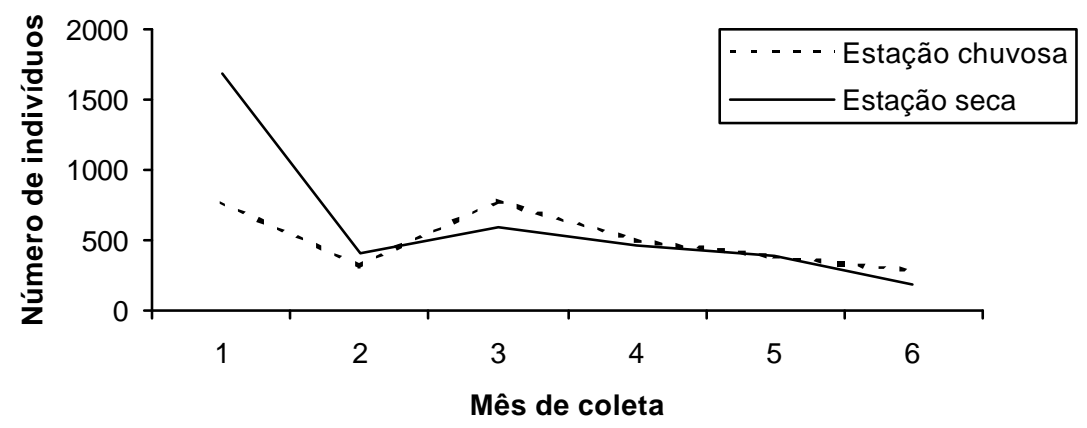

Figura 8 - Número de indivíduos germinados nas amostras do banco de sementes nos meses de fevereiro a julho de 2001 na área B (área de estudo em Iracemápolis, SP).

O número de sementes encontrado na área $B$ foi estatisticamente diferente do valor encontrado para a área $A$, sendo a média no primeiro caso superior a encontrada no segundo (Figura 9). 


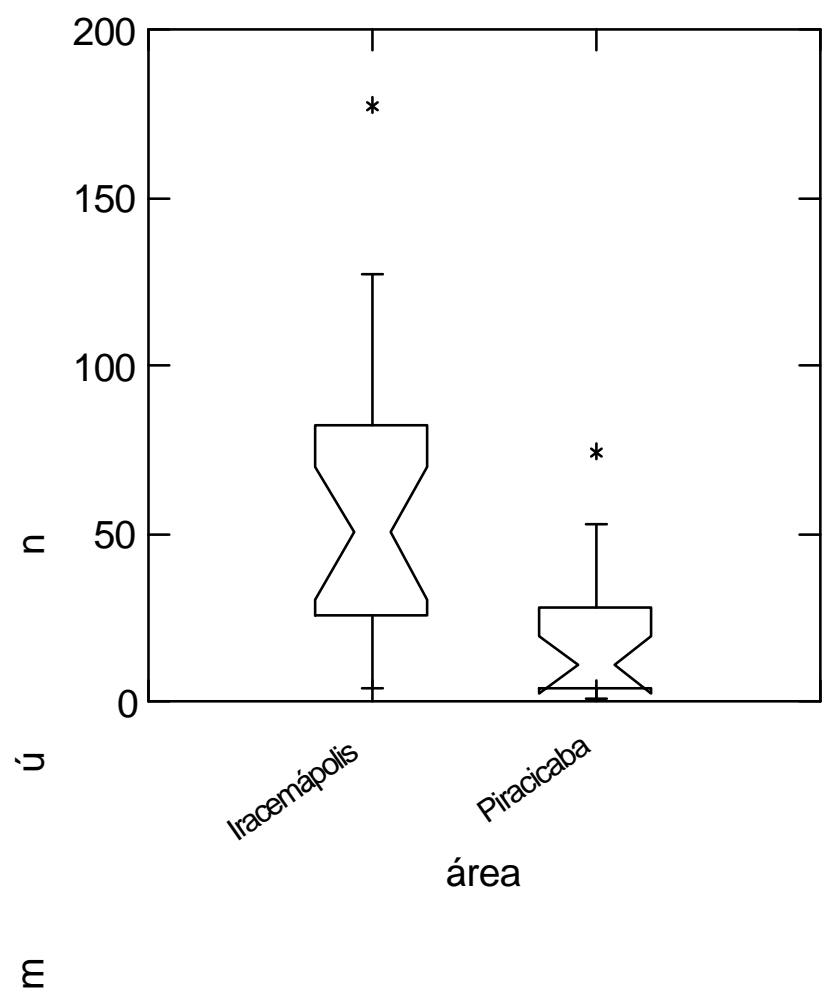

Figura 9 - Comparação do total de sementes germinado nas amostras do banco na área $\mathrm{A}$ (área de estudo em Iracemápolis, SP) e na área $\mathrm{A}$ ( área de estudo em Pifacicaba). Nota explicativa: cada caixa ("box") representa 50\% das observações; as barras verticais inferiores e superiores representam a amplitude total da distribuição (25\% e $75 \%$ ), exceto os valores extremos (*) e os muito extremos $\left({ }^{\circ}\right)$ ("outliers"). A linha horizontal dentro da caixa representa a mediana, e os limites de confiança de 95\% são representados pelas linhas indentadas ao redor da mediana.

○

\subsection{Discussão}

O papel desempenhado pelo banco de sementes do solo, como subsídio necessário para a definição de ações de manejo e restauração, tem sido bastante estudado nos últimos tempos (Dalling et al., 1997; Butler \& Chandon, 1998). As 
investigações realizadas até o momento sugerem que a densidade e diversidade de sementes armazenadas no solo possa fornecer indicações sobre a resiliência de uma determinada área (Williams-Linera, 1993; Onaindia \& Amezaga, 2000), uma vez que a germinação das sementes presentes no banco é uma das fonte de entrada dos indivíduos na comunidade.

Por possuir indivíduos estocados em diferentes épocas e de origens distintas das apresentadas pela comunidade já estabelecida, este estoque de sementes pode reduzir a probabilidade de extinção das populações, retardar taxas de evolução e mesmo alterar a estrutura genética e florística da vegetação (Hyatt \& Casper, 2000).

Os resultados obtidos para o banco de sementes nas duas áreas de estudo indicam que existe um estoque de sementes no solo. Este estoque é bastante reduzido com relação às espécies arbustivas-arbóreas, havendo um predomínio de espécies hebáceas invasoras. Estes resultados estão de acordo com os obtidos por outros autores entre eles Young (1987), Quintana-Ascencio et al. (1996), Guariguata (2000).

Num estudo conduzido por Tekle e Bekele (2000) em áreas degradadas na Etiopia, constatou-se que as espécies herbáceas constituem $75 \%$ do número total de espécies.

No estudo conduzido por Baider e colaboradores (2001) em quatro trechos de floresta Atlântica, com diferentes idades de regeneração, por exemplo, foi observada grande quantidade de espécies herbáceas, variando de 56 a $67 \%$ do total de sementes de acordo com a idade considerada, para as camadas mais superficias do solo. Complementarmente, constatou-se que conforme a floresta torna-se madura há uma redução na densidade total das sementes viáveis, bem como na densidade de sementes herbáceas, e por fim, um aumento na densidade de sementes arbustivasarbóreas.

Grombone-Guaratini (1993) estudando uma floresta de galeira no Brasil encontrou uma predominância de $76 \%$ de espécies herbáceas no banco de sementes.

A densidade total das sementes também foi reduzida em ambas áreas, embora os valores encontrem-se dentro dos descritos por Garwood (1989) de 25 à 3350 sementes. $\mathrm{m}^{-2}$, para florestas tropicais primárias.

Baider e colaboradores (1999), por exemplo, estudando um trecho de floresta Atlântica Montana no sudeste do Brasil encontraram uma densidade média de 872 sementes. $\mathrm{m}^{-2}$. Já Grombone-Guarantini (1999) em seu estudo conduzido numa floresta 
estacional semidecidual perturbada, no interior do estado de São Paulo, encontrou 49,60 sementes. $\mathrm{m}^{-2}$ na estação chuvosa e 32,30 e 46,30 sementes.m ${ }^{-2}$ para as estações secas. Os valores obtidos por esta última autora estão bem abaixo dos encontrados neste estudo.

A baixa diversidade de espécies arbóreas encontrada pode ser resultante de fatores distintos. Uma das primeiras e mais provável razão para tal fato é a própria ausência das sementes destas espécies no banco.

As sementes podem ser enterradas ou perdidas por carreamento através da água e do vento; transportadas até as partes mais profundas do solo por ações de formigas e minhocas; ou morrer em resposta às características genéticas, fisiológicas, e às atividadades de predadores e parasitas.

Adicionalmente, a perda de sementes formadoras do banco pode estar relacionada a fatores ambientais como longos períodos de estiagem, que podem contribuir de maneira significativa para a mortalidade das sementes.

A disponibilidade de sementes em determinada área depende, também, das barreiras encontradas à sua chegada (Wijdeven \& Kuzee, 2000) que incluem atributos locais como aspectos do dossel; da vizinhança como características da matriz na qual estão inseridas as áreas; da capacidade de dispersão dos propágulos ou de vetores que favorecem seu deslocamento; e finalmente de um sítio favorável a sua germinação.

Por outro lado, a dominância de espécies daninhas é também função destas condições locais e de aspectos da vizinhança, urbana na área $A$ e essencialmente agrícola na área $B$. Tal vizinhança contibui para o aporte de espécies invasoras para as áreas restauradas. Simultaneamente, estas matrizes dificultam o fluxo de sementes de fragmentos florestais remanescente, uma vez que poucos agentes dispersores conseguem alcançar grandes distâncias em áreas abertas, devido a falta de recursos e puleiros para pouso, e ainda em função da sua maior visibilidade para ação de predadores (Nepstad et al., 1996; Wunderle, 1997).

O histórico de ocupação destas áreas deve ainda ser considerado nesta análise já que anteriormente estas eram utilizadas para atividades agrícolas. O manejo da cultura de cana-de-açúcar emprega grandes quantidades de herbicidas e freqüentemente ocorrem queimadas nas plantações. Desta foram espera-se que, até implantação do projeto de restauração, estas áreas não apresentavam um acúmulo de 
sementes no solo, o que pode ser considerado mais um fator importante para o baixo número de espécies encontrado no banco destas áreas.

A alta presença de espécies herbáceas de diferentes famílias parece indicar que, em casos de distúrbios com abertura de clareiras, estas espécies se proliferarão de forma bastante acentuada, podendo mesmo pedominar no sub-bosque destas áreas (Turcker \& Murphy, 1997).

Algumas das espécies utilizadas no plantio são características de estágios sucessionais mais avançados. As sementes de tais espécies freqüentemente estão ausentes do banco em função de sua limitada longevidade, disponibilidade esporádica e intensidade de predação (Harper, 1977; Vázque-Yanes \& Orozoco-Segovia, 1993). Além destas características, tais espécies podem estar em período pré-reprodutivo, ou seja, ainda não estão frutificando, dada a pouca idade apresentada pelos plantios.

Como exposto anteriormente, o banco de sementes é composto, predominantemente, por espécies pioneiras que necessitam de altas intensidades de luz para sua germinação e são precoce reprodutivamente.

Desta forma, espera-se que a relação entre as espécies da flora implantada e as do banco seja baixa, uma vez que foram utilizadas espécies de todos os grupos sucessionais. De fato, tal padrão é reconhecido para diversas comunidades de florestas maduras (Arévalo \& Fernández-Palacios, 2000), estágios avançados de sucessão (Guo et al., 2000) e florestas degradadas (Tekle \& Bekele, 2000).

Apesar da baixa similaridade apresentada entre a flora já estabelecida e os indivíduos germinados no banco de sementes, deve-se salientar que algumas das espécies encontradas no banco têm respresentantes na área, como ocorre com a Leucaena leucocephala, Mutingia calabura e Helicteris ovata na área B. Estas são espécies exóticas, bastante agresssivas que se encontram no interior do plantio (observação pessoal).

Outras espécies como Melia azadarach, Eugenia jambos e Cordia myxa possuem frutos carnosos atrativos à fauna, e muito provavelmente, têm sua origem na área $A$ associada a ação destes vetores, principalmente aves.

As espécies presentes no banco nas duas estações de coleta podem ter permanecido dormentes no banco ou ser resultantes de aporte constante no solo via chuva de sementes. Este último caso é provável para espécies como a Leucaena 
leucocephala, Melia azadarach e Cordia myxa, que apresentaram produção de frutos durante todo o período de estudo (Capítulo 4).

A maioria dos indivíduos germinou durante o primeiro mês após incubação do experimento. Este resultado é esperado já grande parte das sementes formadora do banco é fotoblástica positiva, e portanto, estimuladas pelo aumento na intensidade de luz.

A maior porcentagem de espécies arbórea presente no banco é classificada como exótica. No entanto, poucas destas espécies foram plantadas estando sua origem associada, possivelmente, à sua invasibilidade e agressividade como no caso da Leucaena leucochephala.

L. leucochephala é uma espécie bastante comum na região e estava presente nas áreas antes mesmo dos projetos serem implantados. A produção de flores e frutos durante praticamante todo o ano torna possível encontrar indivíduos desta espécie nas duas áreas de estudo, para as duas estações do ano.

Meila azedarach é outra espécie exótica bastante encontrada na área B e que, diferentemente da $L$. leucochephala, foi utilizada no plantio. Esta espécie foi selecionada por produzir grande quantidade de frutos carnosos ao longo do ano, sendo portanto, bastante atrativa à fauna. Assim, é possível encontrar os propágulos de $M$. azedarach nas duas estações de coleta da área $\mathrm{B}$, bem como em todos os meses na chuva de sementes desta mesma área (Capítulo 4).

Os resultados obtidos no levantamento dos indivíduos germinados no banco não demonstraram variação sazonal tanto na densidade quanto na composição das espécies.

Este resultado difere do que freqüentemente é encontrado na maior parte dos trabalhos envolvendo sazonalidade do banco de sementes. Normalmente, esta variação está relacionada a fatores ambientais como períodos de secas que freqüentemente são acompanhados por picos de frutificação, e biológicos como características autoecologicas das espécies que podem determinar o período e a intensidade de frutificação e a longevidade das sementes no banco.

Como em outros estudos (Arévalo \& Fernández-Palacios, 2000) foi possível verificar uma variação espacial no banco de sementes. Esta variação pode ser observada através dos desvios padrão e amplitudes dos valores apresentados pelas espécies, bem com pelo número de indivíduos encontrado em cada parcela. 
Esta heterogeniedade espacial está associada à singularidade de cada microsítio onde foram realizadas as amostras. A presença das sementes é largamente determinada por padrões agregados de mortalidade, predação ou parasitismo, bem como de germinação e dispersão (Jansen, 1970; Howe \& Smallwood, 1982), principalmente com relação às espécies finais de sucessão. Estas espécies tendem a apresentar grandes sementes com baixa capacidade de dispersão, pronta geminação e altas intensidade de herbivoria, principalmente próximo à planta mãe.

Os fatores que podem estar influenciando a abundância e a diversidade de espécies arbóreas no sub-bosque incluem a seleção das espécies plantadas, o tamanho e a idade do plantio, a qualidade do sítio (combinação das propreidades do solo, características fisiográficas etc), tipo e intensidade de utilização passada (agricultura, pecuária) e posição da área na paisagem.

A Área B, por exemplo apresenta maior idade de plantio (14 anos) e na sua implantação foi utilizado um maior número de espécies (140) quando comparado com a área $A$ que foi implantada há 10 anos e onde foram utilizadas 35 espécies. Estes resultados parecem comprovar a importância de se utilizar, nos projetos de restauração, um maior número de espécies possível.

No entanto, é importante ressaltar que os resultados obtidos podem sofrer influência da metodologia utilizada. É reconhecido em literatura que o método de germinação, apesar de ser o mais utilizado dada sua facilidade tanto na manipulação como no reconhecimento das sementes germinadas, entretanto ele apresenta-se limitado por subestimar as amostras, devido a erros associados à dormência e mortalidade das sementes (Brown, 1992).

Além disso, os períodos em que foram realizadas as coletadas das amostras têm profundos efeitos na diversidade encontrada (Lopéz-Mariño, 2000), uma vez que a frutificação de algumas espécies é infreqüente e que muitas destas estão presentes no banco por curtos períodos de tempo. A heterogeneidade espacial do banco é também reponsável por tornar sua amostragem pouco acurada (Strykstraka et al., 1998).

A observação de determinadas espécies no experimento, contudo, não implica que estas espécies estarão presentes na área no mesmo período. No experimento as condições de luz, temperatura e umidade são ideais, o que nem sempre ocorre na natureza. Por outro lado, algumas espécies podem não ser observadas nas amostras do banco por apresentarem sementes com comportamento fotoblástico negativo. 
É importante saber se a disponibilidade de sementes está restringindo a sucessão, principalmente se ela condiciona o estabelecimento de determinadas espécies. Tal conhecimento perimitirá o manejo das áreas para que mais espécies venham a se estabelecer no local.

Esta intervenção pode incluir a indução de clareiras, criação de puleiros artificiais, práticas de enriquecimento e reintodução de espécies entre outros, possibilitando desta forma o melhor desenvolvimento do processo de regeneração.

O conhecimento da dinâmica do banco de sementes de determinada área pode, ainda, auxiliar nas práticas de restauração, uma vez que se conhece a época mais propícia à germinação dos indivíduos.

Por outro lado, este trabalho demonstra que ações de manejo, visando a recuperação de áreas, não podem estar baseadas somente no banco de sementes, tendo em vista que muitas espécies, principalmente aquelas de estágios finais de sucessão, não possuem representantes no banco.

Portanto, deve-se salientar o papel da dispersão das sementes como fonte de chegada de novas espécies e indivíduos para a população, bem como a complementação artificial destas espécies em casos extremos.

\subsection{Conclusões}

- Não foram observadas diferenças significativas no banco de sementes entre as duas estações de coleta, para ambas áreas;

- Verificou-se diferença estatística entre o número de sementes presentes nas duas áreas, sendo o maior valor encontrado para a área B (área de estudo em Iracemápolis);

- A maior porcentagem de espécies encontrada no banco de sementes nas duas áreas foi classificada com herbácea;

- Dentre as espécies arbóreas observadas nas amostras do banco, verificouse o predomínio das exóticas;

- A germinação das sementes presentes nas amostras do banco concentrouse durante o primeiro mês de incubação do experimento; 
- A amostragem das sementes germinadas no banco, revelou que poucas espécies arbóreas estavam presentes, indicando a importância de outras fontes de entrada de indivíduos para a comunidade;

- Pelos motivos expostos acima, podemos dizer que o banco de sementes apresentou poucas informações que nos permitisse avaliar a capacidade de regeneração de áreas restauradas;

- As informações referentes a disponibilidade do banco de sementes, com relação à aspectos de riqueza, diversidade, sazonalidade e capacidade de regeneração, foram insuficientes para torná-lo um bom parâmetro para o monitoramento de áreas restauradas;

- A utilização de outros indicadores em detrimento ou em complementação ao banco de sementes pode fornecer informações mais precisas sobre a disponibilidade de fontes de indivíduos para regeneração e para avalição do sucesso de projetos de restauração. 


\title{
4 CHUVA DE SEMENTES
}

\author{
Autora: LUDMILA PUGLIESE DE SIQUEIRA \\ Orientador: Prof. Dr. RICARDO RIBEIRO RODRIGUES
}

\section{Resumo}

A chuva de sementes foi estudada em uma área restaurada com 14 anos de idade, através de amostras mensais das sementes depositada em 30 coletores de 0,50 $x$ 0,50m, instalados no interior do plantio. Foram encontrados no período de abril de 2001 a março de 2002, 4.435 sementes pertencentes a 36 espécies e 11 famílias numa densidade de 591,33 sementes. $\mathrm{m}^{-2}$. Verificou-se padrão sazonal de frutificação, sendo o fim da estação seca e início da chuvosa a época em que ocorreu maior deposição das sementes. A maior parte das espécies encontradas na chuva de sementes possui síndrome de dispersão zoocórica, sendo a dispersão destas espécies, predominante no período chuvoso. Espécies anemocóricas dispersaram suas sementes predominantemente no fim da estação seca e início da chuvosa. Foi possível observar heterogeneidade espacial na chuva de semente. A maior proporção dos indivíduos encontrados na chuva de sementes foi classificada como exótica e a maioria das espécies pertencentes a estágios iniciais de sucessão. $O$ índice de similaridade entre as espécies encontradas na chuva de sementes e às implantadas no projeto foi de 15,20\%. Apenas três espécies são comuns a chuva de sementes e 0 banco de sementes da mesma região. Os resultados demonstram que a origem da 
maioria das sementes observadas nos coletores está associada a indivíduos adultos em fase de reprodução presentes na área, indicando a importância da utilização de grande número de espécies em projetos de restauração.

\section{THE SEED RAIN}

Author: LUDMILA PUGLIESE DE SIQUEIRA Adviser: Prof. Dr. RICARDO RIBEIRO RODRIGUES

\section{Summary}

The seed rain was studied in a 14-year-old restored area, through monthly samplings of the seeds placed in thirty $0,5 \times 0,5 \mathrm{~m}$ collectors, installed inside the planting. 4.435 seeds were sampled within the period between April 2001 and March 2002 , all of them belonging to 36 species and 11 families in a 591,33 seeds. $\mathrm{m}^{-2}$ density. A fruiting seasonal pattern was verified, being the end of the dry season and beginning of the wet season when the most seeds were captured. Most of the species found at the seed rain has a zoochoric dispersion syndrome, happening mostly at the rainy season. Anemochoric species dispersed their seeds mainly at the end of the dry season and beginning of the wet season. It was possible to observe a spatial heterogeneity in the seed rain. Most of the individuals found at the seed rain were classified as exotic and most species found belong to initial stages of succession. The similarity index among the species found at the seed rain and implanted on the project was of $15,20 \%$. Only three species are common to the seed rain and to the seed bank of the same region. The results show that the origin of most seeds collected is associated to reproductive adult individuals in the area, indicating the importance of using a large number of species in restoration projects. 


\subsection{Introdução}

Os propágulos podem ter sua origem associada a duas fontes: o banco de sementes e a chuva de sementes. O banco de sementes, como já descrito no capítulo 3, é constituído pelo conjunto de sementes viáveis resultante do balanço entre processo de perdas e ganhos. A chuva de sementes, por sua vez, é representada pelo transporte de propágulos, como resultado do processo de dispersão.

Dispersão é o movimento pelo qual os indivíduos escapam do ambiente de seus pais, tornando sua distribuição menos agregada; trata-se de um processo biológico fundamental que opera em escala espacial e temporal (Nathan, 2001). É responsável por padrões demográficos e interações genéticas dos indivíduos emergentes (Kalisz et al., 1999). Desta forma a dispersão das sementes pode contribuir para coexistência das espécies e amenizar o efeito da exclusão competitiva. Tem efeito determinante na taxa de fluxo genético, influenciando a estrutura genética inter e intracomunidades.

A importância do processo de dispersão tem sido enfatizado por diversos autores, como Darwin, C, MacArthur R.H. e Willson E.O. Várias hipóteses foram formuladas para explicar a importância deste processo. Howe \& Smallwood (1982) citam em seu trabalho duas das hipóteses mais conhecidas: a Hipótese de Escape (Janzen, 1970 \& Connell, 1971) que implica no sucesso diferencial das espécies que escapam da vizinhança dos indivíduos reprodutores, dada as altas taxas de mortalidade dependente de densidade próxima a planta matriz; e a Hipótese da Colonização (Baker, 1974) que assume que as sementes dispersas, levadas a ambientes mais afastados, possam encontrar locais mais favoráveis a sua germinação e sobrevivência.

O fluxo de indivíduos numa área resulta tanto do processo de dispersão local (autóctone) como o de sementes provenientes de outras localidades (alóctone). Neste último caso, agentes dispersores exercem papel fundamental no transporte das semente (Martínez- Ramos \& Soto-Castro, 1993). Adicionalmente, muitas espécies de plantas apresentam estruturas especializadas que aumentam sua segurança e eficiência na dispersão (Willson, 1993): podendo citar, entre outras, plumas e asas em casos de anemocoria; frutos carnudos, arilos, ganchos, pêlos e espinhos para frutos dispersos por animais. 
A maioria das sementes dispersa, entretanto, se encontra pouco afastada da fonte de origem, seguindo um modelo de distribuição conhecido com curva Leptocurtica (Harper, 1977; Willson, 1993). Este padrão prevê a queda na densidade de sementes conforme se distancia da planta mãe, afinando-se numa extensa calda representado longas dispersões. Strykstra et al. (1998) ressaltam que a parte mais interessante da curva para a restauração vegetal é aquela posterior à moda da curva, ou sua calda. Estes autores sugerem que a observação desta parte da curva permite estimar as chances das sementes alcançarem novas áreas influenciando nos processos de sucessão e na colonização destes ambientes.

A avaliação da disponibilidade de semente em projetos de recuperação de áreas degradadas é essencial uma vez que tal aspecto condiciona e limita o processo de regeneração (Dalling et al., 1998; Wijdeven \& Kuzee, 2000). Projeções, com base na avaliação desta disponibilidade, são fundamentais para antecipar a necessidade de intervenções adicionais (Strykstra et al., 1998) permitindo, desta forma, otimização no desenvolvimento da atividade restauradora.

Neste sentido, aspectos de ecologia de paisagem, como o tamanho e formato da área em questão, seu grau de isolamento e conectância, proximidade com corredores ecológicos e de fluxo genético e o tipo de matriz em que se insere, são determinantes no fluxo de propágulos e animais dispersores na área, influindo portanto no processo de restauração (Parker, 1997).

Projetos de restauração, como ressaltado no capítulo 2, têm por objetivo o desenvolvimento de um ecossistema sustentável. Para seu sucesso é necessário, portanto, o restabelecimento de processos ecológicos fundamentais, como relações de interações. No caso específico da dispersão das sementes, relações mutualísticas estão na base do processo.

Desta forma, a atração de agentes dispersores deve fazer parte dos esforços empregados em ações restauradoras. Wunderle (1997) indica que atração da avifauna e de mamíferos voadores está diretamente associada à disponibilidade de puleiros, recursos alimentares e complexidade estrutural da área. Robinson \& Handel (1992) e McClanahan \& Wolfe (1993) ressaltam ainda o importante papel de agentes dispersores no processo de adição de espécies vegetais em áreas restauradas. Num estudo conduzido por Andersen \& Morrison (1998) na Austrália, avaliou-se o papel das 
formigas na dispersão das sementes e sua possível utilização para avaliação de sucesso de ações restauradoras.

Padrões sazonais de frutificação são reconhecidos em literatura (ex. Caldato et al., 1996; Penhalber \& Mantovani, 1997) e afetam a disponibilidade de sementes no banco, e influíndo, significativamente, no potencial de regeneração de áreas (Grombone-Guarantini, 1999).

O presente estudo está baseado na hipótese de que a chuva de sementes possa fornecer indicativos sobre a capacidade de regeneração da área. Tem ainda como objetivo:

i) Avaliar a capacidade de regeneração das áreas restauradas através da presença, ou não da chuva de sementes;

ii) Verificar se há variação sazonal na chuva de sementes de acordo com os meses do ano;

iii) Verificar se a chuva de sementes constituiu um bom indicador para a avaliação de sucesso de projetos de restauração.

\section{2 Área de estudo}

- Localização geográfica e caracterização física

A área de estudo (área B) localiza-se no Município de Iracemápolis, situada a, situada à $22^{\circ} 35^{\prime} S$ de latitude e $47^{\circ} 31^{\prime} \mathrm{W}$ de longitude.

O estudo foi conduzido na área restaurada, de aproximadamente 20 ha, às margens da represa de abastecimento público municipal, fazendo parte da microbacia do Ribeirão Cachoeirinha (Anexo B). O plantio desta região foi realizado em 1987 apresentando, portanto, 14 anos de idade na época em que foi realizado o estudo.

A área é cercada por uma estrada de terra, de aproximadamente 2 metros de largura, que funciona como um aceiro entre ao plantio e a área do entorno, dominada por cultura de cana-de-açúcar. Nesta áreas é possível observar diferentes estratos e o dossel apresenta-se com aproximadamente $10 \mathrm{~m}$ de altura (levantamento realizado com 200 indivíduos).

O clima nesta região é do tipo Cwa na classificação de Köpen, com índice pluviométrico variando de 1.100 a $1.700 \mathrm{~mm}$ anuais. Foram encontrados na região 5 grupos de solo: Latossolo Roxo distrófico; Latossolo Vermelho Amarelo Húmico; 
Latossolo Roxo eutrófico; Terra Roxa Estruturada; Podzôlico Vermelho-Amarelo abruptico. O solo predominate na microbacia é o do grupo Latossolo Roxo distrófico.

- Caracterização do projeto de restauração

A microbacia do Ribeirão Cachoeirinha apresenta uma área aproximada de 1.500 ha, sendo $92,80 \%$ desta ocupada por cultura de cana-de-açúcar; o restante está distribuído entre três represas, áreas ribeirinhas, mata natural, reflorestamento de eucalipto, pastagens, benfeitorias e cultura de milho. As consequências desta desproporcional ocupação e uso da terra que determinaram o depauperamento do reservatório público, motivaram o governo local determinar a desapropriação de uma faixa de $50 \mathrm{~m}$ de contorno dos reservatórios e de $30 \mathrm{~m}$ ao longo de todos os rios da microbacia. Após esta desapropriação foi feita a revegetação destas áreas.

Como a área revegetada historicamente era usada para o plantio de cana-deaçúcar, foi adotada, como prática de preparo de solo, duas gradeações pesadas, que impediram a rebrota da cana. Para a conservação do solo nas áreas de pantio, principalmente nas fases iniciais, foi construído no contorno do reservatório, um terraço numa faixa com $50 \mathrm{~m}$ de largura e declividade de 1\%, com o objetivo de disciplinar e controlar as condições de escoamento superficial e de infiltração das águas superficiais e de infiltração das águas pluviais.

A maioria dos indivíduos utilizados no plantio da área pertence a espécies arbóreas ocorrentes em remanescentes de formações florestais da região, tendo sido selecionada a partir de levantamentos florísticos e fitossiológicos destes remanescentes. Foram introduzidas ainda algumas espécies frutíferas, no intuito de atrair a fauna regional, facilitando com isso o fluxo de propágulos na área e algumas exóticas agressivas na faixa de bordadura, para amenizar os efeitos do cultivo da cana do entorno da área restaurada (Rodrigues et al., 1992) (Anexo C).

No plantio, as espécies foram combinadas em módulos baseados nos conceitos de sucessão secundária. Cada módulo continha 9 indivíduos, num espaçamento inicial de $4 \times 4$ metros e numa segunda fase do plantio $3 \times 3$ metros. Em cada módulo foram implantados 6 indivíduos de espécies pioneiras, 2 de secundárias iniciais, para 1 de secundária tardia ou climax. Foram utilizadas para a recuperação desta área 140 espécies apresentadas no Anexo A. 
Em função da interferência causada pela flutuação do nível de água do reservatório, foram criadas duas diferentes sub-áreas: sub-área I, adjacente ao curso de água, numa faixa de $3 \mathrm{~m}$, onde foram introduzidas espécies típicas de condição ciliar, adaptadas a períodos variáveis de inundação do solo; e sub-área II que fica paralela a primeira, possuindo espécies típicas de floresta Estacional Mesófila Semidecídua, não sujeitas à encharcamento do solo.

\subsection{Metodologia}

\subsubsection{Zoneamento das áreas e desenho amostral}

Inicialmente, foi feito o reconhecimento da área onde foi desenvolvido o projeto de pesquisa, para então serem alocadas as parcelas.

Com esta finalidade, a áreas foi seccionada ao longo de sua maior extensão em segmentos unitários $100 \mathrm{~m}$ de comprimento e largura variável de acordo com o próprio desenho da área (compondo 10 segmentos na área $\mathrm{A}$ e 32 na na área B). Foram instaladas estacas nas bordas destes segmentos delimitando suas áreas. $\mathrm{O}$ interior de cada um destes compartimentos foi vistoriado, procurando-se identificar características fisionômicas e ambientais. Assim foram analisados os seguintes descritores:

- distância mínima de posicionamento em relação à borda equivalente a 10m;

- condições parecidas de cobertura vegetal do trecho total a ser amostrado ;

- sem domínio de espécies invasoras herbáceas;

- ausência de clareiras;

- sem interferência antrópica;

- solo não sujeito à inundação;

- sem desnível topográfico.

Cada um dos segimentos foi então classificado de acordo com estas características em:

ambiente 1 - todas exigências atendidas;

ambiente 2 - poucas exigência não atendidas;

ambiente 3 - poucas exigências atendidas.

Como critério de alocação de parcelas foram priorizados aqueles segmentos que mais atendessem às condições acima especificadas. 
Com base nestas informações, foram escolhidos os locais de instalação das parcelas. Foram alocadas 10 parcelas amostrais de $10 \times 10 \mathrm{~m}$ totalizando uma área de 0,1 ha.

Segundo este critério de classificação ambiental adotadopara os segmentos, foram instaladas seis parcelas em ambiente 1 , e as quatro parcelas restantes, em ambiente 2. Todas as parcelas apresentam espaçamento $4 \times 4 \mathrm{~m}$.

\subsubsection{A chuva de sementes}

Foram instalados em cada parcela, três coletores de sementes de forma aleatória, totalizando 30 coletores na área. Os coletores foram confeccionados com ferros chatos, cantoneira e forrados com tela de nylon (com malhas de $80 \%$ de sombreamento), estruturados em forma de quadrados de $0,5 \mathrm{~m}$ de lado e a uma altura de $10 \mathrm{~cm}$ do solo. A área total amostrada foi de $7,5 \mathrm{~m}^{2}$.

Foram realizadas coletas mensais do material depositado no período de abril de 2001 a março de 2002. Este material foi recolhido e acondicionado em saco de papel, devidamente rotulado e transportado para o laboratório. As amostras foram postas para secar em temperatura ambiente, e posteriormente, o material foi granulometricamente separado por um conjunto de peneira (GRANUTEST - Telastem peneiras para análise LTDA) de diferentes tamanho de malha, com aberturas de 4,0; 2,$0 ; 1,0$ e $0,5 \mathrm{~mm}$.

As sementes foram identificadas mediante consulta bibliográfica e a especialistas, e comparadas com as dos indivíduos presentes na área em fase de frutificação. Aquelas não identificadas foram classificadas como morfoespécie e fixadas para serem usadas como mostruário facilitando, assim, futuras identificações de indivíduos da mesma espécie. Em cada amostra foram verificados aspectos como densidade, diversidade e grupos sucessionais (segundo Gandolfi, 1991) das espécies encontradas.

Foram calculados os parâmetros fitossociológicos de densidade e frequência absoluta e relativa (Müeller-Dombois \& Ellenberg, 1974) e o índice de similaridade de Sorensen das amostras obtidas. 


\subsection{Resultados}

Foram capturados, no período de abril de 2001 a março de 2002, 4.435 sementes numa área total de $7,5 \mathrm{~m}^{2}$, em trinta coletores de $50 \times 50 \mathrm{~cm}$. A densidade média de deposição durante o período de estudo foi 591,33 sementes.m ${ }^{-2}$. A média de indivíduos obtida por parcela foi de 147,90 ( $\pm 139,51)$ para o período de um ano.

Os indivíduos encontrados estão divididos entre 36 espécies de 11 famílias. Doze espécies não foram identificadas e um indivíduo foi identificado em nível de gênero (Tabela 11).

O número de sementes depositado por parcela durante o período de estudo variou entre 30,33 a 497,33 indivíduos e o número de espécies variou entre 4,00 e 8,33 .

Em vinte e nove amostras não foi possível observar o material depositado em função de furto e danos causados aos coletores. Apenas nos meses de julho, novembro e dezembro foram obtidas todas as amostras (30) do material depositado.

Os parâmetros fitossociológicos das sementes depositadas nos coletores estão apresentados na Tabela 12. Dentre as espécies encontradas, Melia azadarach foi a que obteve maiores valores para densidade relativa $(26,74 \%)$.

Nenhuma espécie foi encontrada em todos os coletores e $44,74 \%$ (17) das espécies estiveram presentes em apenas um coletor. Destas, apenas três foram encontradas em mais de um mês. Em todos os meses foi possível observar indivíduos de Cordia myxa, Leuceana leucocephala e Melia azadarach.

As seguintes espécies são comuns à chuva de sementes e à flora implantada no projeto de restauração: Bauhinia forficata, Balfourdendron riedelianum, Cecropia pachystachya, Cedrela Fissilis, Cordia myxa, Cordia superba, Ficus benjamina, Inga edulis, Jacaranda mimosaefoilia, Meila azadarah, Parapiptadenia rigida, Piptadenia colubrina, Piptadenia gonoacantha, Pterocarpus violaceus, Pterogyne nitens, Schinus terebintifolius Tabebuia chrysotricha, Tipuana tipo e Triplaris surinamensis. Tal número de espécies em comum determinou o índice de similaridade de Sorensen o valor de $15,20 \%$. As espécies que tiveram sementes presentes nos coletores porém não foram utilizadas no plantio foram: Leucaena leucocephala, Tecoma stans, Enterolobium conotrtisiliquum e Clitoria farchildiana. 
Tabela 11. Relação das espécies arbustivas-arbóreas, número total de indivíduos (№ Ind), média e desvio padrão, Grupo ecológico (Ex-exótica; P-pioneiras, Sisecundarias iniciais, S-secundárias, St-secundária tardia) e síndrome de dispersão (Zoo-zoocórica; Anemo-anemocórica, Auto-autocórica) das sementes presentes em 30 coletores instalados na área $B$ (área de estudo em Iracemápolis, SP) durante o período de estudo (abril de 2001 a março de 2002).

\begin{tabular}{|c|c|c|c|c|c|c|}
\hline Família & Espécie & Autor & $\begin{array}{l}\mathrm{N}^{\circ} \\
\text { Ind }\end{array}$ & $\begin{array}{c}\text { Média } \pm \\
\text { Devio }\end{array}$ & Gurpo & Dispesão \\
\hline Meliaceae & Melia azedarach & L. & 1.271 & $42,36 \pm 65,81$ & Ex & Zoo \\
\hline Cecropiaceae & Cecropia pachystachya & Trécul. & 1.040 & $34,67 \pm 109,63$ & $\mathrm{P}$ & Zoo \\
\hline Mimosaceae & Leucaena leucocephala & (Lam.) de Wit & $\begin{array}{l}722 \\
336\end{array}$ & $\begin{array}{l}27,77 \pm 59,49 \\
1120+1760\end{array}$ & $\begin{array}{l}\text { Ex } \\
\mathrm{Si}\end{array}$ & Auto \\
\hline $\begin{array}{l}\text { Boraginaceae } \\
\text { Bignoniaceae }\end{array}$ & Tecoma stans & (L.) Juss.ex.H.B.K & 276 & $9,20 \pm 16,66$ & Ex & Anemo \\
\hline Anacardiaceae & Schinus terebinthifolius & Raddi. & 134 & $4,47 \pm 9,28$ & $\mathrm{P}$ & Zoo \\
\hline Bignoniaceae & Jacaranda mimosaefolia & D.Don. & 121 & $4,03 \pm 12,64$ & $\mathrm{Si}$ & Anemo \\
\hline Mimosaceae & Piptadenia colubrina & (Vell.) Benth. & 67 & $2,23 \pm 3,98$ & St & Auto \\
\hline Indeterminada & morfoespécie 29 & & 67 & $2,23 \pm 4,83$ & & Zoo \\
\hline Indeterminada & morfoespécie 32 & & 67 & $2,23 \pm 7,06$ & & Anemo \\
\hline Fabaceae & Tipuana tipu & (Benth.) Kuntze & 63 & $2,00 \pm 3,13$ & Ex & Anemo \\
\hline Polygonaceae & Triplaris surinamensis & Cham. & 60 & $2,00 \pm 3,13$ & $\mathrm{~S}$ & Anemo \\
\hline Indeterminada & Bauhinia forficata & Link & 59 & $1,97 \pm 4,17$ & $\mathrm{P}$ & Auto \\
\hline Bignoniaceae & morfoespécie 28 & & 56 & $1,87 \pm 5,67$ & & Anemo \\
\hline Meliaceae & Cedrela fissilis & Vell. & 15 & $0,50 \pm 1,46$ & $\mathrm{Si}$ & Anemo \\
\hline Indeterminada & morfoespécie 26 & & 14 & $0,47 \pm 0,91$ & & Zoo \\
\hline Mimosaceae & Inga edulis & Mart. & 12 & $0,04 \pm 0,90$ & Si & Zoo \\
\hline Boraginaceae & Cordia superba & Cham. & 12 & $0,04 \pm 0,90$ & $\mathrm{Si}$ & Zoo \\
\hline Mimosaceae & Piptadenia gonoacantha & (Mart.) J.F.Macbr. & 6 & $0,20 \pm 0,53$ & $\mathrm{Si}$ & Auto \\
\hline Rutaceae & Balfourodendron riedelianum & (Engl.) Engl. & 5 & $0,17 \pm 0,32$ & St & Zoo \\
\hline Caesalpinaceae & Pterogyne nitens & Tul. & 4 & $0,17 \pm 0,42$ & $\mathrm{Si}$ & Anemo \\
\hline Indeterminada & morfoespécie 30 & & 4 & $0,13 \pm 0,42$ & & Zoo \\
\hline Indeterminada & morfoespécie 35 & & 4 & $0,13 \pm 0,42$ & & Zoo \\
\hline Indeterminada & morfoespécie 12 & & 3 & $0,10 \pm 0,32$ & & Anemo \\
\hline Mimosaceae & Enterolobium contortisiliquum & (Vell.) Morong. & 2 & $0,07 \pm 0,21$ & $\mathrm{Si}$ & Auto \\
\hline Apocynaceae & morfoespécie 15 & & 2 & $0,07 \pm 0,21$ & & $?$ \\
\hline Caesalpinaceae & Cassia sp & & 2 & $0,07 \pm 0,14$ & & Auto \\
\hline Bignoniaceae & Tabebuia chrysotricha & $\begin{array}{l}\text { (Mart. ex DC) } \\
\text { Standl }\end{array}$ & 2 & $0,07 \pm 0,14$ & S & Anemo \\
\hline Fabaceae & Clitoria fairchildiana & Howard. & 2 & $0,07 \pm 0,21$ & Ex & Auto \\
\hline Fabaceae & Pterocarpus violaceus & Vogel & 1 & $0,07 \pm 0,01$ & $\mathrm{Si}$ & Anemo \\
\hline Moraceae & Ficus benjamin & L. & 1 & $0,07 \pm 0,01$ & $\mathrm{Si}$ & Zoo \\
\hline Leguminosa & morfoespécie 21 & & 1 & $0,07 \pm 0,01$ & & Auto \\
\hline Mimosaceae & Parapiptadenia rigida & (Benth.) Brenan & 1 & $0,07 \pm 0,01$ & St & Auto \\
\hline Indeterminada & morfoespécie 31 & & 1 & $0,07 \pm 0,01$ & & $?$ \\
\hline Indeterminada & morfoespécie 12 & & 1 & $0,07 \pm 0,01$ & & ? \\
\hline Indeterminada & morfoespécie 10 & & 1 & $0,07 \pm 0,01$ & & ? \\
\hline Indeterminada & morfoespécie 17 & & 1 & $0,07 \pm 0,01$ & & $?$ \\
\hline
\end{tabular}


Tabela 12. Parâmetros fitossociológicos (freqüência absoluta - Fa; freqüência relativa Fr; densidade absoluta - Da; densidade relativa - Dr) dos indivíduos presentes na chuva de sementes, em 30 coletores instalados na área $B$ (área de estudo em Iracemápolis) para o perído de estudo (março de 2001 a maio de 2001).

\begin{tabular}{|c|c|c|c|c|c|}
\hline Espécie & Autor & $\mathrm{Fa}(\%)$ & $\mathrm{Fr}(\%)$ & $\begin{array}{c}\mathrm{Da} \\
\text { (Ind.m-2) }\end{array}$ & $\operatorname{Dr}(\%)$ \\
\hline Melia azedarach & L. & 73,33 & 11,83 & 14,88 & 26,74 \\
\hline Cordia myxa & L. & 60,00 & 9,68 & 4,07 & 7,31 \\
\hline Tecoma stans & (L.) Juss.ex.H.B.K & 53,33 & 8,60 & 3,67 & 6,59 \\
\hline Schinus terebinthifolius & Raddi. & 53,33 & 8,60 & 1,77 & 3,19 \\
\hline morfoespécie 29 & & 46,67 & 7,53 & 0,88 & 1,58 \\
\hline Triplaris surinamensis & Cham. & 40,00 & 6,45 & 0,78 & 1,41 \\
\hline Tipuana tipu & (Benth.) Kuntze & 40,00 & 6,45 & 0,81 & 1,46 \\
\hline Piptadenia colubrina & (Vell.) Benth. & 26,67 & 4,30 & 0,89 & 1,61 \\
\hline morfoespécie 26 & & 23,33 & 3,76 & 0,17 & 0,31 \\
\hline Leucaena leucocephala & (Lam.) de Wit & 20,00 & 3,23 & 8,72 & 15,67 \\
\hline morfoespécie 28 & & 16,67 & 2,69 & 0,75 & 1,34 \\
\hline Cordia superba & Cham. & 16,67 & 2,69 & 0,16 & 0,29 \\
\hline Jacaranda mimosaefolia & D.Don. & 13,33 & 2,15 & 1,61 & 2,90 \\
\hline Balfourodendron riedelianum & (Engl.) Engl. & 13,33 & 2,15 & 0,07 & 0,12 \\
\hline Cedrla fissilis & Vell. & 13,33 & 2,15 & 0,20 & 0,36 \\
\hline Pterogyne nitens & Tul. & 10,00 & 1,61 & 0,05 & 0,10 \\
\hline Bauhinia forficata & Link & 10,00 & 1,61 & 0,79 & 1,41 \\
\hline morfoespécie 32 & & 10,00 & 1,61 & 0,89 & 1,61 \\
\hline Cassia sp & & 6,67 & 1,08 & 0,03 & 0,05 \\
\hline morfoespécie 35 & & 6,67 & 1,08 & 0,05 & 0,10 \\
\hline morfoespécie 15 & & 6,67 & 1,08 & 0,03 & 0,05 \\
\hline Inga $\epsilon$ & Mart. & 6,67 & 1,08 & 0,16 & 0,29 \\
\hline Piptadenia gonoacantha & (Mart.) J.F.Macbr. & 6,67 & 1,08 & 0,08 & 0,14 \\
\hline Cecropia pachystachya & Trécul. & 3,33 & 0,54 & 13,87 & 24,92 \\
\hline Clitoria fairchildiana & Howard. & 3,33 & 0,54 & 0,01 & 0,02 \\
\hline Ficus benjamin & L. & 3,33 & 0,54 & 0,01 & 0,02 \\
\hline Enterolobium contortisiliquum & (Vell.) Morong. & 3,33 & 0,54 & 0,03 & 0,05 \\
\hline morfoespécie 10 & & 3,33 & 054 & 0,01 & 0,02 \\
\hline morfoespécie 12 & & 3,33 & 0,54 & 0,04 & 0,07 \\
\hline pécie 21 & & 3,33 & 0,54 & 0,01 & 0,02 \\
\hline via chrysotricha & & 3,33 & 0,54 & 0,02 & 0,05 \\
\hline & & 3,33 & 0,54 & 0,05 & 0,10 \\
\hline morfoespécie 31 & & 3,33 & 0,54 & 0,01 & 0,02 \\
\hline Parapiptadenia rigida & (Benth.) Brenan & 3,33 & 0,54 & 0,01 & 0,02 \\
\hline Pterocarpus violaceus & Vogel & 3,33 & 0,54 & 0,01 & 0,02 \\
\hline morfoespécie 17 & & 3,33 & 0,54 & 0,01 & 0,02 \\
\hline
\end{tabular}


Indivíduos de Cordia myxa, Leucaena leucocephala e Melia azadarach foram encontrados tanto na chuva de sementes quanto no banco de sementes da mesma área, em suas duas estações de coleta.

Verificou-se variação temporal no número de sementes e de espécies depositados nos coletores. Foram encontrados dois picos no número de indivíduos (Figura 10): um destes picos encontra-se entre os meses de setembro e outubro; o outro pico, encontrado no mês de março, pode ser explicado pela alta concentração de indivíduos (1040 sementes) de uma única espécie, num fruto de Cecropia. A média mensal mais baixa obtida foi para o mês de junho $(1,96 \pm 0,83)$. Excluindo o mês de março, o mês que obteve a maior média mensal foi setembro com $25,78( \pm 23,67)$. Um maior número de espécies foi encontrado entre os meses de agosto a dezembro (Figura 11).

A maior proporção, cerca de 55,44\% (2334) dos indivíduos e 21,74\% (5) das espécies foi classificada com exótica, considerando nesta análise apenas aquelas sementes identificadas, depositadas nos coletores (total de 4210). As espécies pioneiras somaram 29,23\% (1231) dos indivíduos e 13,04\% (3) das espécies; espécies iniciais contribuíram com 11,83\% (498) dos indivíduos e 39,13\% (9) das espécies; espécies tardias foram as que contribuíram com o menor número de individuos, apenas 3,49\% (147) dos indivíduos e 26,09\% (6) das espécies (Figura 12).

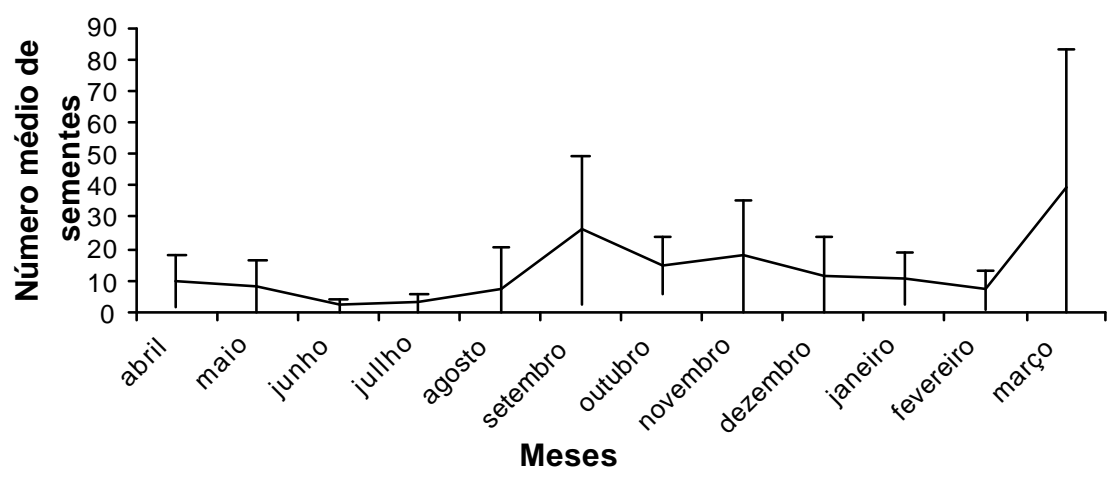

Figura 10 - Média mensal dso indivíduos depositados nos coletores durante o período de estudo (abril de 2001 a março 2002) para a área B (área de estudo em Iracemápolis, SP). Linhas verticais representam os desvios acima e abaixo da média. 


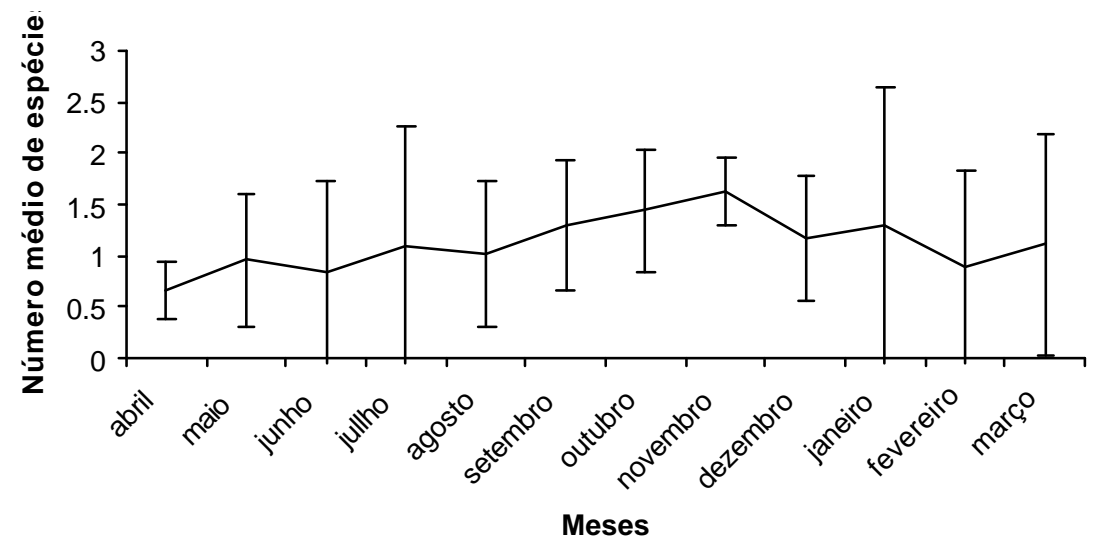

Figura 11 - Média mensal das espécies depositadas nos coletores durante o período de estudo (abril de 2001 a março 2002) para a área B (área de estudo em Iracemápolis, SP). Linhas verticais representam os desvio acima e abaixo das médias.

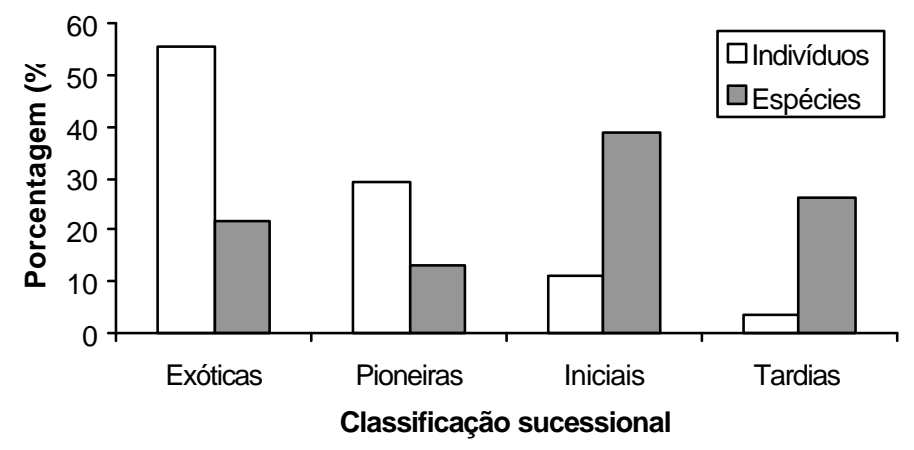

Figura 12 - Porcentagem dos indivíduos e espécies, agrupados segundo sua classificação sucessional para as sementes depositadas nos coletores durante o período de estudo (abril de 2001 a março 2002). Nesta análise foram consideradas apenas as sementes identificadas em nível de espécies.

A maior parte de todas as sementes depositadas nos coletores possui síndrome de dispersão zoocórica, correspondendo a 33,33\% (12) das espécies e 65,39\% (2900) dos indivíduos. Espécies anemocóricas correspondem a 30,60\% (11) das espécies e 
15,06\% (668) dos indivíduos. As espécies atucóricas somaram 25,00\% (9) das espécies e 19,43\% (862) dos indivíduos. Ficaram sem determinação, 11,11\% (4) das espécies e $0,11 \%$ (5) dos indivíduos (Figura 13).

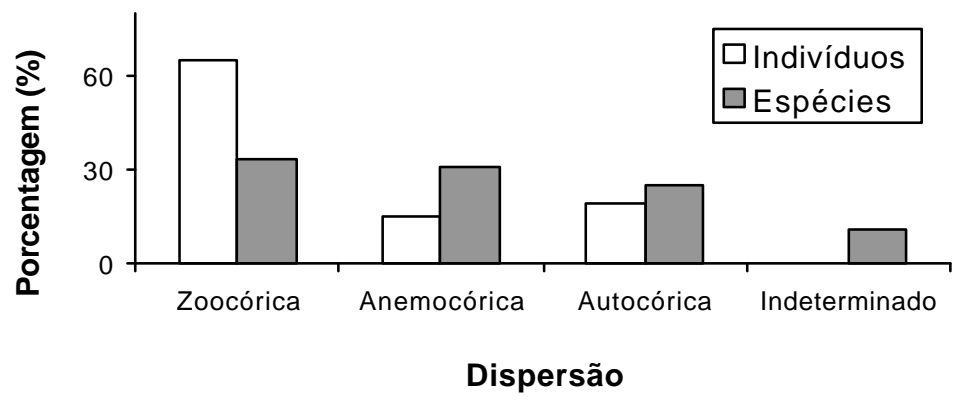

Figura 13 - Porcentagem de espécies e indivíduos agrupados conforme síndrome de dispersão para as sementes depositadas no período de um ano (abril de 2001 a março de 2002) para a área B (área de estudo em Iracemápolis, $\mathrm{SP})$.

Observou-se variação sazonal na proporção de espécies, havendo o predomínio de espécies anemocóricas no fim da estação seca e início da chuvosa, correspondendo aos meses de agosto a novembro, e das espécies zoocóricas na estação chuvosa, de dezembro a maio, como ilustra a Figura 14.

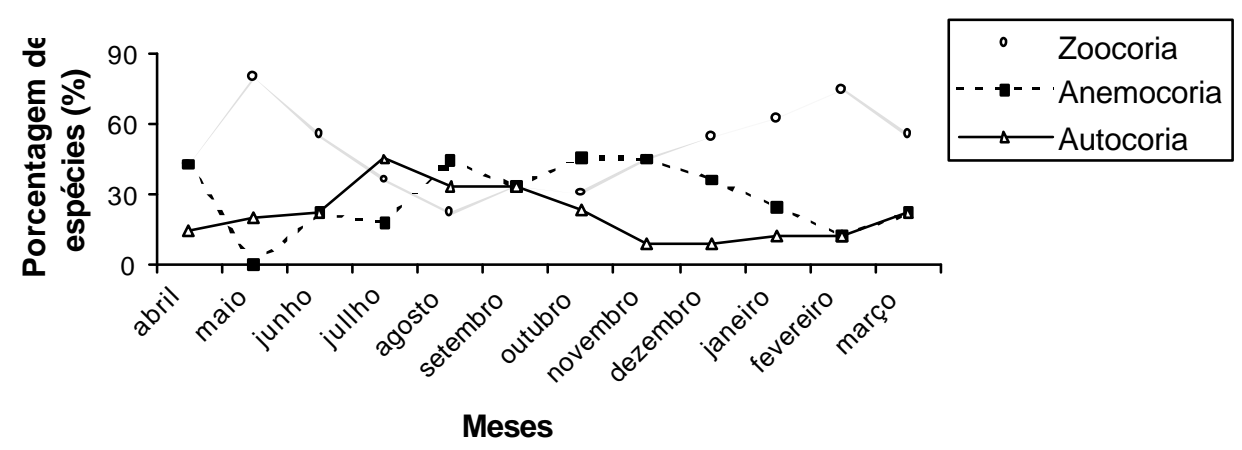

Figura 14 - Porcentagem de espécies agrupadas conforme síndrome de dispersão nos meses de abril de 2001 a março de 2002, para a área B (área de estudo em Iracemápolis, SP). 


\subsection{Discussão}

O padrão da chuva de sementes representa a fase inicial de organização de florestas tropicais (Clark et al., 2001) visto que a maiora das espécies produzem sementes com baixa longevidade no banco. $O$ entendimento destes padrões torna-se fundamental para a compreensão dos mecanismos de regeneração natural.

Foram depositados 4.435 indivíduos de 36 morfoespécies nos coletores instalados no interior da área B.

A chuva de sementes apresentou padrão sazonal. O número de espécies depositada nos coletores foi mais constante do que o número de indivíduos, que variou bastante entre os meses. O fim da estação seca e início da chuvosa foi o período onde foi depositado o maior número de sementes nos coletores. Observou-se o predomínio de espécies zoocóricas durante a estação chuvosa e de espécies anemocóricas na fim da estação seca e no início da chuvosa. Este padrão foi observado em outros estudos com o de Penhalber \& Mantovani (1997), e os de Gromboni-Garatini (1999), ambas no estado de São Paulo em florestais estacionais secundárias.

Épocas de floração e frutificação são estimuladas por fatores ambientais externos como intensidade de luz, temperatura e umidade, bem como as condições do solo entre outros.

Morellato (1992) indica que a maturação dos frutos possa estar relacionada a condições ambientais favoráveis à germinação das sementes. Esta mesma autora indica, ainda, que para espécies anemocóricas a estação seca favorece a dispersão das sementes, por ocasião da queda das folhas do dossel e à ação dos ventos, mais intensos nestas épocas. Assim, espera-se que a dispersão ocorra em épocas favoráveis tanto à dispersão quanto ao estabelecimento das espécies.

Entretanto, padrões sazonais de frutificação são, principalmente, determinados por estímulos internos, os quais controlam sua taxa de desenvolvimento (Penhalber \& Mantovani, 1997).

Além desta variação sazonal é possível reconhecer padrões espaciais na dispersão das sementes. A amplitude encontrada na riqueza e na densidade de sementes entre parcelas, bem como os desvios encontrados para as espécies, demonstram esta heterogeneidade espacial. 
Clarck \& Poulsen (2001) demonstraram em seu estudo que a maioria dos indivíduos encontrados nos coletores foram depositados sob a copa de um indivíduo co-específico. De fato, muitos autores admitem que a a maioria das sementes se encontre pouco afastada da planta matriz (Harper, 1977; Willson, 1993; Strykstra et al., 1998). Igualmente, na área estudada foi possível observar que a maior parte das sementes depositada nos coletores pertencia às espécies em frutificação próximas ao local de coleta.

A abundância e a distribuição espacial das espécies em frutificação também podem desempenhar um papel importante na chuva de sementes (Martínez-Ramos \& Soto-Castro, 1993).

A disponibilidade e a eficiência de agentes dispersores influenciam o padrão de distribuição das espécies. Estudos analisando o papel de aves na adição de espécies em áreas fragmentadas (McClanahan \& Wolfe, 1993) ou em estágios de recuperação e regeneração (Armstrong \& Nichols, 2000) demonstram a importância deste processo.

A similaridade entre os indivídos depositados na chuva de sementes e a flora implantada no projeto de restauração demonstra que grande parte das espécies depositadas nos coletores de semente, possivelmente, tem sua origem associada aos indivíduos adultos presentes na área.

A chegada de sementes alóctones pode ser limitada por aspectos da paisagem como tamanho do plantio, seu grau de isolamento e tipo de matriz na qual se insere. Como afirmado anteriormente, a área $B$ encontra-se em uma região bastante fragmentada e dominada por cultura canaviera.

Assim é bastante improvável o fluxo de sementes, uma vez que, as fontes produtoras estão isoladas em fragmentos e as características da matriz adjacente não facilitam a ação de agentes dispersores.

A arborização urbana da vizinhança pode estar contribuindo para o aporte de espécies exóticas - tipicamente utilizadas com fins estéticos e ornamentais - para a área do plantio, como é o caso da Tecoma stans.

A maior parte destas espécies presente na chuva de sementes foi classificada como secundária inicial, seguida pelas secundárias tardias, exóticas e por fim as pioneiras. Entretanto, em se tratando do número de indivíduos estes valores se invertem, sendo a maior quantidade encontrada de exóticas, seguidos por pioneiras, 
secundárias inicias e tardias. Novamente observamos a agressividade de espécies exóticas, que mesmo em menor riqueza conseguem produzir maior número de frutos.

A zoocoria foi a síndrome de dispersão mais representada entre os indivíduos e espécies, o que é confirmado para florestas tropicas (Howe \& Smallwood, 1982). Porém, o número de espécies zoocóricas pouco diferiu das anemocóricas, fato que para alguns autores pode ser indicativo de perturbação.

Pode-se dizer que densidade de deposição de sementes para o período de estudo está dentro dos valores encontrado para outros estudos. Gromboni-Guaratini, 1999 encontrou uma densidade de 441,71 sementes. $\mathrm{m}^{-2}$ para uma florestas estacional semidecidual perturbada pertencentes a 54 espécies; Penhalber \& Mantovani (1997) encontraram densidade igual 1.804 sementes. $\mathrm{m}^{-2}$ num total de 90 espécies; Holl (1999), estudando a regeneração em uma área de pastagem abandonada na Costa Rica, encontrou densidade de 1.670 sementes. $\mathrm{m}^{-2}$ entre 63 espécies para a área de floresta e de 190 sementes. $\mathrm{m}^{-2}$ pertencentes a 18 espécies para a área de pasto.

Entretanto é importante lembrar que diversos fatores metodológicos podem estar condicionando os resultados. Strykstra et al. (1998), indicam que espécies mais abundantes serão mais capturadas e que isto é inerente ao método.

O tamanho das malhas utilizadas nos coletores de sementes pode determinar o tamanho das sementes coletadas. Assim também a malha das peneiras utilizadas para a separação das sementes pode não ser suficientemente pequeno para capturar todas os indivíduos coletados. Também, a área total amostral deve ser considerada na análise destes resultados.

Além disso a questão da heterogeneidade espacial e temporal da chuva de sementes pode tornar sua amostragem pouco precisa. Algumas espécies apresentam padrões de frutificação supra-anual, e desta forma, dificilmente serão amostrados em estudos de curta duração.

A ausência de coletores na maioria dos meses de coleta, contribui para a menor acuidade dos dados. 


\subsection{Conclusões}

- A maior proporção das espécies observada na chuva de sementes foi caracterizada como exótica;

- Espécies com síndrome de dispersão zoocórica predominaram entre os indivíduos depositados nos coletores;

- Verificou-se variação sazonal na deposição das sementes, sendo o fim da estação seca e início da estação chuvosa o período em que foi coletados um maior número de indivíduos;

- Espécies anemocóricas dispersaram suas sementes predominantemente no fim da estação seca e início da chuvosa;

- Espécies zoocóricas predominaram entres as coletadas durante a estação chuvosa;

- A chuva de sementes apresentou importantes informações sobres a disponibilidade de sementes para a avaliação da capacidade de regeneração das áreas restauradas;

- As informações obtidas acerca da riqueza de espécies, diversidade de indivíduos e padrões de heterogeneidade espacial e temporal da chuva de sementes, indicam que este possa ser considerado um bom parâmetro para o monitoramento das áreas restauradas;

- Entretanto, as dificuldades apresentadas na avaliação e identificação dos indivíduos depositados nos coletores, bem com a incerteza da realização do potencial dos indivíduos presentes na chuva de sementes, podem limitar sua precisão como indicador do sucesso de projetos de restauração 


\title{
5 ESTRATO DE REGENERAÇÃO
}

\author{
Autora: LUDMILA PUGLIESE DE SIQUEIRA \\ Orientador: Prof. Dr. RICARDO RIBEIRO RODRIGUES
}

\section{Resumo}

O estrato de regeneração de duas áreas restauradas com diferentes idades de plantio (área A com 10 anos e área B com 14 anos) foi avaliado através do levantamento de todos os indivíduos com altura entre $0,3 \mathrm{~m}$ e $2 \mathrm{~m}$ em 30 parcelas de $1 \times 1 \mathrm{~m}$ instaladas em cada uma das áreas. Os indivíduos regenerantes presentes nas subparcelas foram registrados, identificados e medidos semestralmente. $\mathrm{Na}$ área $\mathrm{A}$ foram amostrados um total de 17 indivíduos de Leucaena leucocephala e 1 indivíduo de Schinus terebintifolius. A densidade média encontrada nesta área foi menor do que um. $\mathrm{Na}$ área $\mathrm{B}$ foram amostrados um total de 53 indivíduos distribuídos entre 15 espécies e 11 famílias. A densidade média obtida nesta área foi igual a 1 indivíduo. $\mathrm{m}^{-}$ 2. Foi encontrada uma maior porcentagem de indivíduos pertencentes a espécies exóticas em ambas as áreas. $\mathrm{Na}$ área $\mathrm{B}, 33,33 \%$ das espécies amostradas foram classificadas como exóticas, $20,00 \%$ como pioneiras, 26,67\% como iniciais, 13,33\% como tardias e 6,67\% são características de sub-bosque. A área B apresentou um total de 6 espécies em comum entre o estrato de regeneração e as espécies implantadas no projeto de restauração; na área $A$ foi encontrada apenas uma espécie em comum. A altura média dos indivíduos encontrados na segunda amostragem foi superior a encontrada na primeira. Espécies pioneiras apresentaram maior incremento na altura. 
Observou-se baixa similaridade entre os indivíduos amostrados na chuva e no banco de sementes com os encontrados no estrato de regeneração, indicando que o desenvolvimento desta comunidade poderá causar mudanças na composição das espécies.

\section{THE REGENERATION STRATUM}

Author: LUDMILA PUGLIESE DE SIQUEIRA Adviser: Prof. Dr. RICARDO RIBEIRO RODRIGUES

\section{Summary}

The regeneration stratum in two restored areas with different ages of planting (area A was 10 years old and area B was 14) was evaluated through a sampling of all the individuals with height varying between 0,30 and $2 \mathrm{~m}$, in thirty $1 \times 1 \mathrm{~m}$ parcels installed in each area. The individuals present in the sub-parcels were registered, identified and measured every semester. In area A, a total of 17 Leucaena leucochephala individuals and 1 Schinus terebintifolius individual were sampled. The average density in this area was smaller than one. In area B a total of 53 individuals from 15 species and 11 families were sampled. The average density in this area was one individual. $\mathrm{m}^{-2}$. A higher percentage of individuals from exotic species in both areas was found. In area B, $33,33 \%$ of sampled species were classified as exotic, $20,00 \%$ were pioneers, $26,67 \%$ were initials, $13,33 \%$ were late secondary and $6,67 \%$ were understory. Area B presented a total of 6 species in common between the regeneration stratum and the species implanted in the restoration project; in area A just one of the species was found in common. The average height of the individuals found on the second sampling was higher than in the first one. Pioneer species presented more increase in height. It was also observed a low similarity among the individuals of the seed rain and the seed bank and the ones found in the regeneration stratum, indicating, 
thus, that the development of this community can cause changes in the species composition.

\subsection{Introdução}

O conhecimento atual sobre os fatores que afetam o recrutamento de espécies para o dossel das comunidades deriva, principalmente, do estudo de estágios inicias do ciclo de vida das plantas (Guariguata, 1998). A probabilidade de um dado indivíduo, de uma determinada espécie, alcançar o dossel da floresta é, freqüentemente, determinada por sua performance como plântula (Finzi \& Canham, 2000).

O recrutamento de indivíduos pode se dar através da germinação de sementes originadas na chuva ou no banco, processos já descritos nos capítulos anteriores. Espécies que compõem o banco, freqüentemente necessitam de maior intensidade de luz para sua germinação e estabelecimento. Grande parte das espécies que germina prontamente após a dispersão forma o banco de plântulas que permanece, temporariamente, sob o dossel da floresta. A disponibilidade de sementes para a germinação pode variar sazonalmente, obedecendo a padrões de floração, frutificação e dispersão de cada espécie.

Entretanto, a sobrevivência e crescimento das espécies, durante os estágios iniciais, de plântulas e indivíduos jovens, são os maiores obstáculos responsáveis pelo afunilamento do número de indivíduos, que alcança os estratos superiores (Kobe, 1999). Este processo influencia, em última análise, a composição e estrutura das espécies (Brokaw \& Scheiner, 1989) assim como a dinâmica da floresta. Por tais motivos, a germinação, recrutamento, sobrevivência e crescimento de plântulas e jovens têm sido objeto de diversos estudos.

Os fatores limitantes ao estabelecimento dos indivíduos passam por questões bióticas e abióticas. Dentre os aspectos abióticos, a disponibilidade de luz é tida como um dos principais fatores limitantes.

As copas das árvores, que compõem os diversos estratos da floresta, são responsáveis por filtrar grande parte da luz incidente na área. Uma revisão extensa sobre este assunto pode ser encontrada no trabalho de Gandolfi (2000). George \& 
Bazzaz (1999 a, b) em seus trabalhos, por exemplo, analisaram o papel do subbosque como um filtro ecológico influenciando a composição e estrutura do dossel.

Dentro desta abordagem, estudos analisando o papel de distúrbios em comunidades são fundamentais e bem documentados na literatura (ex. Schupp, 1988; Alvarez-Buylla \& Martinez-Ramos, 1992; Clarck \& Clarck, 1993; Denslow, 1980,1995; Kobe, 1999; Schnitzer \& Carson, 2001). A maior parte deste trabalhos destaca a influência da abertura do dossel na coexistência das espécies e na manutenção da diversidade, em função do aumento na luminosidade e na disponibilidade de recursos. A formação deste microhabitat pode contribuir para redução dos níveis de competição, dada as diferenças na capacidade de dispersão entre $\propto$ indivíduos, bem como de requerimentos específicos exigidos para germinação de cada espécie (partição de recursos).

Ainda dentre os fatores abióticos, aspectos relativos à composição e características do solo como disponibilidade de nitrogênio são reconhecidamente limitantes para o crescimento das plantas (Finzi \& Canham, 2000). O papel dos danos mecânicos, causados pela queda de galhos ou árvores, o pisoteamento por animais, e o sombreamento pela serapilheira, são considerados na taxa de sobrevivência e crescimento dos indivíduos (Clarck \& Clarck, 1989; Guariguata, 1998; Scariot, 2000).

Com relação aos fatores bíoticos, a predação (Schupp, 1988) e parasitismo (Facelli \& Pickett, 1991) durante os estágios iniciais (de sementes e plântulas) influenciam, significativamente, os padrões de regeneração, tendo a dispersão um papel importante na redução da mortalidade dependente de densidade próximo a planta mãe.

Laska (1997) sugere que a investigação do estrato inferior da floresta possa fornecer informações sobre a regeneração natural na área; entretanto a aspectos do subbosque têm sido negligenciados em muitos estudos em Florestas Tropicais.

$\mathrm{Em}$ áreas restauradas, por outro lado, o estrato inferior é freqüentemente analisado, visto que a recolonização natural da vegetação, com a adição de novas espécies e formas de vida, é fundamental na avaliação do sucesso do projeto (ex. Tucker \& Murphy, 1997; Haggar et al., 1997; Keenan, et al., 1997; Grayson et al., 1999; Souza, 2000; Leopold et al., 2001; Parrotta \& Knowles, 2001). Tal aspecto permite inferir se os processos de dinâmica vegetal como a sucessão e regeneração natural, 
foram reestabelecidos e se seguirão seu curso, sem que haja necessidade de intervenções.

Este estudo está baseado na hipótese de que indivíduos jovens possam fornecer indicativos sobre a capacidade de regeneração da área. Tem como objetivo:

i) Verificar a presença de indivíduos jovens regenerantes no sub-bosque das áreas estudadas;

ii) Avaliar a composição, densidade e dinâmica destes indivíduos;

iii) Avaliar se os dados obtidos constituem um bom indicador para a avaliação de sucesso de projetos restauração.

\section{2 Áreas de estudo}

O estudo foi desenvolvido em duas áreas restauradas no interior de São Paulo. A primeira destas localiza-se na cidade de Piracicaba e segunda no Município de Iracemápolis. Apesar de apresentarem diferentes idades de plantio (a primeira área com 10 anos e a segunda com 14 anos), estas áreas foram restauradas baseadas no mesmo modelo de restauração. Tal modelo está fundamentado nos conceitos de sucessão secundária, utilização de espécies nativas regionais e padrão de disitribuição espacial dos indivíduos de acordo com os parâmetros quantitativos e sucessionais das espécies encontradas nos remanescentes florestais da região.

A seguir estão relacionadas as características específicas de cada uma destas áreas. $A$ área de estudo em Piracicaba será identificada como área $A$ e a área de estudo em Iracemápolis como área B.

\subsection{1 Área de estudo em Piracicaba}

- Localização geográfica e caracterização física

A primeira área localiza-se na cidade de Piracicaba, situada à $22^{\circ} 42^{\prime} \mathrm{S}$ de latitude e, $47^{\circ} 38^{\prime}$ W de longitude.

O estudo foi conduzido numa área restaurada à margem esquerda do Rio Piracicaba, dentro do perímetro urbano numa área de aproximadamente 2,4 há, com $370 \mathrm{~m}$ de comprimento e largura variável de 15 e $75 \mathrm{~m}$ (Anexo B). Esta área é limitada de um lado pelo rio Piracicaba e de outro por uma avenida, denominada avenida 
Bandeirantes. O plantio desta região foi realizado em 1991, estando no ano de coleta de dados com 10 anos de idade.

Esta região apresenta clima, Cwa segundo Köpen, caracterizado como mesotérmico ou sub-úmido, de inverno seco, com temperatura média do mês mais frio inferior a $18^{\circ} \mathrm{C}$ e a média do mais quente entre $23^{\circ} \mathrm{C}$ e $24^{\circ} \mathrm{C}$. A pluviosidade média anual nesta região é de 1.200 a $1.300 \mathrm{~mm}$.

Antes da instalação do projeto de restauração, o solo das covas onde seriam plantadas as mudas foi trocado, pois a área era utilizada para despejo de restos de material de construção. As covas foram então preenchidas com latossolo vermelho trazido de áreas de empréstimo.

- Caracterização do projeto de restauração

No início do reflorestamento havia uma cobertura vegetal presente na área que era composta basicamente de vegetação herbácea, alguns aglomerados de leucena (Leucaena leucocephala), remanescente de ingá (Inga vera) e aproximadamente 200 indivíduos de espécies nativas, resultantes de um plantio simbólico. Todos os indivíduos arbóreos existentes foram mantidos.

Como afirmado anteriormente privilegiou-se, na escolha das espécies, as nativas regionais, considerando ainda aspectos sucessionais e parâmetros quantitativos dessas espécies nos remanescentes florestais da região (Rozza et al., 1992).

As espécies foram agrupadas em módulos de nove indivíduos, num espaçamento de 2,5 x 2,5m. Em cada módulo foram implantados 6 indivíduos de pioneiras, 2 secundárias iniciais e uma secundária tardia ou clímax. Nesta área foram utilizadas 35 espécies, numa densidade de 1.600 ind/ha. A lista de espécies utilizadas no plantio é apresentada em anexo (Anexo A).

Em função da interferência causada pelas flutuações do nível da água do rio, foram criadas duas diferentes sub-áreas: sub-área I, adjacente ao curso de água, numa faixa de $5 \mathrm{~m}$, onde foram introduzidas espécies típicas de condição ciliar, adaptadas a períodos variáveis de inundação do solo; e sub-área II que fica paralela a primeira, possuindo espécies típicas de Floresta Estacional Semidecídual (1993), não sujeitas à encharcamento do solo. 
O plantio apresenta-se hoje com dossel a uma altura média estimada em $9 \mathrm{~m}$ (levantamento de 200 indivíduos). O subosque nesta área é bastante aberto em função de roçadas e cortes freqüentes, promovidos por funcionários da prefeitura, para manutenção da limpeza e segurança no local (Anexo C).

Numa faixa de aproximadamente 5 metros ao longo do Rio há um predomínio da espécie Leucaena leucocepha, não só na área área de plantio mas ao longo de toda sua extensão, formando um aglomerado que domina a paisagem. Entretanto, é possível verificar diversar espécies utilizadas no plantio quando nos aproximamos da sua faixa mais externa, próxima a avenida Bandeirantes .

\subsection{2 Área de estudo em Iracemápolis}

- Localização geográfica e caracterização física

A segunda área de estudo (área B) localiza-se no Município de Iracemápolis, situada a, situada à $22^{\circ} 35^{\prime} S$ de latitude e $47^{\circ} 31^{\prime} \mathrm{W}$ de longitude.

O estudo foi conduzido na área restaurada, de aproximadamente 20 ha, às margens da represa de abastecimento público municipal, fazendo parte da microbacia do Ribeirão Cachoeirinha (Anexo B). O plantio desta região foi realizado em 1987 apresentando, portanto, 14 anos de idade na época em que foi realizado o estudo.

A área é cercada por uma estrada de terra, de aproximadamente 2 metros de largura, que funciona como um aceiro entre ao plantio e a área do entorno, dominada por cultura de cana-de-açúcar. Nesta áreas é possível observar diferentes estratos e o dossel apresenta-se com aproximadamente $10 \mathrm{~m}$ de altura (levantamento realizado com 200 indivíduos).

O clima nesta região é do tipo Cwa na classificação de Köpen, com índice pluviométrico variando de 1.100 a $1.700 \mathrm{~mm}$ anuais. Foram encontrados na região 5 grupos de solo: Latossolo Roxo distrófico; Latossolo Vermelho Amarelo Húmico; Latossolo Roxo eutrófico; Terra Roxa Estruturada; Podzôlico Vermelho-Amarelo abruptico. O solo predominate na microbacia é o do grupo Latossolo Roxo disrtófico.

- Caracterização do projeto de restauração

A microbacia do Ribeirão Cachoeirinha apresenta uma área aproximada de 1.500 ha, sendo 92,8\% desta ocupada por cultura de cana-de-açúcar; o restante está 
distribuído entre três represas, áreas ribeirinhas, mata natural, reflorestamento de eucalipto, pastagens, benfeitorias e cultura de milho. As consequências desta desproporcional ocupação e uso da terra que determinaram o empobrecimento do reservatório público, motivaram o governo local determinar a desapropriação de uma faixa de $50 \mathrm{~m}$ de contorno dos reservatórios e de $30 \mathrm{~m}$ ao longo de todos os rios da microbacia. Após esta desapropriação foi feita a revegetação destas áreas.

Como a área revegetada historicamente era usada para o plantio de cana-deaçúcar, foi adotada, como prática de preparo de solo, duas gradeações pesadas, que impediram a rebrota da cana. Para a conservação do solo nas áreas de plantio, principalmente nas fases iniciais, foi construído no contorno do reservatório, um terraço numa faixa com $50 \mathrm{~m}$ de largura e declividade de $1 \%$, com o objetivo de disciplinar e controlar as condições de escoamento superficial e de infiltração das águas superficiais e de infiltração das águas pluviais.

A maioria dos indivíduos utilizados no plantio da área pertence a espécies arbóreas ocorrentes em remanescentes de formações florestais da região, tendo sido selecionada a partir de levantamentos florísticos e fitossiológicos destes remanescentes. Foram introduzidas ainda algumas espécies frutíferas, no intuito de atrair a fauna regional, facilitando com isso o fluxo de propágulos na área e algumas exóticas agressivas na faixa de bordadura, para amenizar os efeitos do cultivo da cana do entorno da área restaurada (Rodrigues et al., 1992).

No plantio, as espécies foram combinadas em módulos baseados nos conceitos de sucessão secundária. Cada módulo continha 9 indivíduos, num espaçamento inicial de $4 \times 4$ metros e numa segunda fase do plantio $3 \times 3$ metros. Em cada módulo foram implantados 6 indivíduos de espécies pioneiras, 2 de secundárias iniciais, para 1 de secundária tardia ou climax. Foram utilizadas para a recuperação desta área 140 espécies apresentadas no (Anexo C).

Em função da interferência causada pela flutuação do nível de água reservatório, foram criadas duas diferentes sub-áreas: sub-área I, adjacente ao curso de água, numa faixa de $3 \mathrm{~m}$, onde foram introduzidas espécies típicas de condição ciliar, adaptadas a períodos variáveis de inundação do solo; e sub-área II que fica paralela a primeira, possuindo espécies típicas de floresta Estacional Mesófila Semidecídua, não sujeitas a encharcamento do solo. 


\subsection{Metodologia}

\subsubsection{Zoneamento das áreas e desenho amostral}

Inicialmente, foi feito o reconhecimento das áreas onde foi desenvolvido o projeto de pesquisa, para então serem alocadas as parcelas.

Com esta finalidade, cada uma das áreas foi seccionada ao longo de sua maior extensão em segmentos unitários de $100 \mathrm{~m}$ de comprimento e largura variável de acordo com o próprio desenho da área, (totalizando 10 segmentos na área $A$ e 32 na na área B). Foram instaladas estacas nas bordas destes segmentos delimitando suas áreas. $\mathrm{O}$ interior de cada um destes compartimentos foi vistoriado, procurando-se identificar características fisionômicas e ambientais. Assim foram analisados os seguintes descritores:

- distância mínima de posicionamento em relação à borda euqivalente a 10m;

- condições parecidas de cobertura vegetal do trecho total a ser amostrado ;

- sem domínio de espécies invasoras herbáceas;

- ausência de clareiras;

- sem interferência antrópica;

- solo não sujeito à inundação;

- sem desnível topográfico.

Cada um dos seguimentos foi então classificado de acordo com estas características em:

ambiente 1 - todas exigências atendidas;

ambiente 2 - poucas exigência não atendidas;

ambiente 3 - poucas exigências atendidas.

Como critério de alocação de parcelas foram priorizados aqueles seguimentos que mais atendessem às condições acima especificadas.

Com base nestas informações, foram escolhidos os locais de instalação das parcelas. Em cada uma das áreas foram alocadas 10 parcelas amostrais de $10 \times 10 \mathrm{~m}$ totalizando uma área de 0,1ha.

Segundo este critério de classificação ambiental adotado para os segmentos, verificou-se a seguinte distribuição: 
$\mathrm{Na}$ área $\mathrm{A}$ seis parcela foram instaladas em ambientes classificados como 2 e quatro parcelas foram localizadas em ambiente tipo 3.

$\mathrm{Na}$ área $\mathrm{B}$ foram instaladas seis parcelas em ambiente 1 , e as quatro parcelas restantes, em ambiente 2 . Todas as parcelas desta área apresentam espaçamento $4 \mathrm{x}$ $4 \mathrm{~m}$.

\subsubsection{O estrato de regeneração}

Para a avaliação do estrato de regeneração, foram demarcadas, em cada uma das parcelas amostrais, subparcelas de $1 \times 1 \mathrm{~m}$, alocadas de forma casualizada. Foram amostradas 3 subparcelas em cada parcela, totalizando $30 \mathrm{~m}^{2}$ em cada área.

Nestas subparcelas foram amostrados todos os indivíduos com altura superior a $30 \mathrm{~cm}$ e menor que $2 \mathrm{~m}$. Os indivíduos amostrados foram devidamente marcados com etiquetas plásticas numeradas.

Foram obtidas amostras dos indivíduos das morfoespécies inventariadas, com exemplares encontradas fora das parcelas. Estes indivíduos foram identificados por comparação com material do Herbário da Escola Superior de Agronomia "Luiz de Quiroz", consulta bibliográfica e a especialista.

O estrato de regeneração foi vistoriado semestralmente, verificando-se sua riqueza, diversidade, taxa de mortalidade e crescimento dos indivíduos durante um ano.

Foram calculados ainda os parâmetros fitossociológico de densidade e frequência absoluta e relativa (Müeller-Dombois \& Ellenberg 1974) e o índice de similaridade de Sorensen. 


\subsection{Resultados}

\subsection{1 Área A}

No levantamento do estrato de regeneração (indivíduos maior que $0,3 \mathrm{~m}$ e menor que $2 \mathrm{~m}$ ) foram amostrados um total 18 indivíduos de 2 espécies, numa área igual $30 \mathrm{~m}^{2}$. Tal resultado determinou a densidade média encontrada que foi inferior a 1 indivíduo.m $m^{-2}(0,60 \pm 0,68)$.

Das dez parcelas avaliadas, em um total de quatro, o número de indivíduos encontrado foi igual a zero; em três foi menor que 1; e nas restantes a densidade encontrada esteve entre 1 e 2 indivíduos. $\mathrm{m}^{-2}$.

O número de espécies por parcelas, como esperado pela baixa riqueza encontrada, foi inferior a 1 em nove das dez parcelas. Apenas em uma parcela a riqueza foi igual a 1. Portanto, a média de indivíduos por parcela foi inferior a um $(0,26$ $\pm 0,31)$.

As duas espécies encontradas no levantamento foram: Schinus terebintifolius com 1 indivíduo, e Leucaena leucocephala com 17 indivíduos.

Leucaena leucocephala foi a espécie que apresentou valores mais elevados para freqüência absoluta (23,33\%), freqüência relativa $(87,5 \%)$ bem como de densidade absoluta $\left(0,56\right.$ ind. $\left.\mathrm{m}^{-2}\right)$ e relativa $(94,40 \%)$; densidade média obtida foi de $0,59( \pm 0,68)$ indivíduo. $m^{-2}$.

Os parâmetros fitossociológicos encontrados para Schinus terebintifolius foram (3,33\%) para freqüência absoluta; $(12,50 \%)$ para freqüência relativa; $\left(0,03\right.$ ind. $\left.\mathrm{m}^{-2}\right)$ de densidade absoluta e (5,60\%) de densidade relativa; densidade méda de indivíduos encontrada foi igual a 0,03 $( \pm 0,1)$ indivíduo. $\mathrm{m}^{-2}$.

Estes valores demonstram a dominância de uma única espécie no estrato de regeneração, sendo esta uma espécie exótica e altamente agressiva.

Como esperado, a altura média dos indivíduos na primeira estação foi inferior ao encontrado após um ano (Figura 15) 


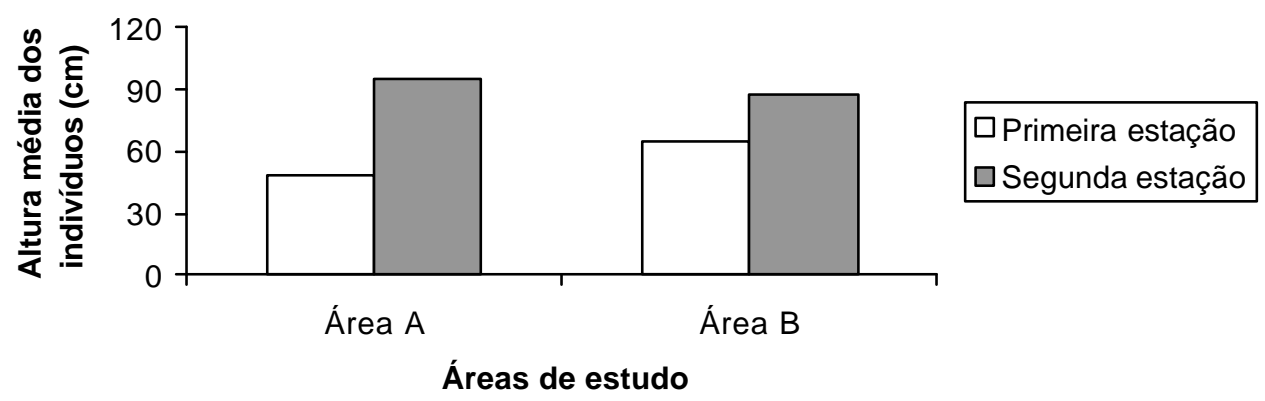

Figura 15 - Altura média dos indivíduos amostrado no estrato de regeneração nas duas estações de coleta, para as áreas de estudo (área $A$ - área de estudo em Piracicaba, SP e área B - área de estudo em Iracemápolis, $\mathrm{SP})$

Schinus terebinthifolius é comum ao estrato de regeneração e à flora utilizada no projeto de restauração, sendo o índice de similaridade de Sorensen obtido de 5\%.

Leucaena leucocephala é comum ao estrato de regeneração e às espécies germinadas no banco de sementes para as duas estações.

A taxa de mortalidade obtida no período de um ano para esta área foi de $14 \%$. O único indivíduo encontrado da espécies Schinus terebinthifolius morreu durante este período.

\subsection{2 Área B}

Foram amostrados um total de 53 indivíduos arbustivo-arbóreos (maiores que 0,3 $\mathrm{m}$ e menores que $2 \mathrm{~m}$ ), distribuídos entre 15 espécies e 11 famílias (Tabela.13) numa área igual a $30 \mathrm{~m}^{2}$.

Uma comparação do número de indivíduos por parcela indica que em 3 destas há menos de um indivíduo, enquanto a parcela mais densa apresentou 4 indivíduos por subparcela. O número médio de indivíduos encontrados por parcela foi de $1,76( \pm 1,30)$ indivíduos. $\mathrm{m}^{-2}$. 
Tabela 13. Relação das espécies, grupo ecológico, forma de vida e número total de indivíduos amostrados no levantamento do estrato de regeneração (>0,3 m e $<2 m$ ) da área $B$ (área de estudo em Iracemápolis, SP).

\begin{tabular}{|c|c|c|c|c|c|}
\hline Família & Espécie & Autor & $\begin{array}{c}\text { Grupo } \\
\text { Ecológico }\end{array}$ & $\begin{array}{l}\text { Forma } \\
\text { de vida }\end{array}$ & $\begin{array}{l}\mathrm{N}^{\circ} \\
\text { ind }\end{array}$ \\
\hline Sapindaceae & Alectryon cf tomentosum & Radlk. & Ex & Av & 23 \\
\hline Lauraceae & Nectandra megapotamica* & (Spreng.) Mez. & $\mathrm{Si}$ & Av & 6 \\
\hline Mimosaceae & Leucaena leucocephala & (Lam.) de Wit & Ex & Av & 5 \\
\hline Fabaceae & Centrolobium tomentosum* & Guill. ex Benth. & Si & Av & 5 \\
\hline Piperaceae & Piper gaudichaudianum & Kunth. & $\mathrm{Sb}$ & $\mathrm{Ab}$ & 3 \\
\hline Bignoniaceae & Tabebuia chrysotricha* & (Mart. ex DC.) Standl. & S & Av & 2 \\
\hline Melastomataceae & Tibouchina sellowiana* & (Cham.) Cogn & $P$ & Av & 1 \\
\hline Bignoniaceae & Tecoma stans & (L.) Juss.ex.H.B.K & Ex & Av & 1 \\
\hline Bignoniaceae & Tabebuia roseo-alba & (Ridl.) Sand. & $\mathrm{Si}$ & Av & 1 \\
\hline Rutaceae & Murraya paniculata & (L.) Jack. & Ex & Av & 1 \\
\hline Fabaceae & Lonchocarpus muehlbergianus* & Hassl. & $\mathrm{Si}$ & Av & 1 \\
\hline Sterculiaceae & Helicteres ovata & Lam. & Ex & Av & 1 \\
\hline Mimosaceae & Enterolobium contortisiliquum & (Vell.) Morong. & $\mathrm{Si}$ & Av & 1 \\
\hline Solanaceae & Cestrum laevigatum & Schltdl. & $P$ & Av & 1 \\
\hline Anacardiaceae & Astronium graveolens* & Jacq. & St & Av & 1 \\
\hline
\end{tabular}

A parcela com maior número de espécies apresentou em média 2 espécies. $m^{-2}$. Em quatro parcelas a média de espécies encontrada foi inferior a 1 espécies. $\mathrm{m}^{-2}$. $\mathrm{A}$ média de sementes obtida nesta área foi de 1,00 $( \pm 0,67)$ espécies. $m^{-2}$.

Alectryon cf tomentosum foi a espécie que obteve valores mais elevados para densidade relativa (43,40\%), seguida por Nectandra megapotâmica $(11,32 \%)$ e Leucaena leucocephala (9,43\%) (Tabela.14). Por outro lado, 9 espécies apresentaram densidade relativa igual a $1,89 \%$. Os parâmetros fitossociológiocos e o número total de plântulas por amostra estão relacionados na Tabela 14.

A Figura 16 apresenta a porcentagem de indivíduos por espécies encontrados no levantamento do estrato de regenerção. Na Figura 17 são apresentadas as porcentagens de indivíduos e espécies segundo grupo sucessional.

A vegetação já estabelecida e os indivíduos em regeneração apresentaram 6 espécies em comum: Astronium graveolens, Centrolobium tomentosum, Lonchocarpus muehlbergianus, Nectandra megapotamica, Tabebuia chrysotricha e Tibouchina sellowiana (Tabela 13). Este valor representa $40,00 \%$ de todas as espécies 
encontradas no estrato de regeneração e apenas $4,28 \%$ da vegetação estabelecida. Esta variação é resultado do número de espécies encontrado em cada situação: 15 na regeneração e 140 na flora implantada no projeto de restauração.

O índice de Sorensen obtido entre as espécies implantadas no projeto de restauração e as levantadas no estrato de regeneração foi de 7,74\%.

Nesta área, apenas um indivíduo da espécies Leucaena leucocephala morreu durante o período de estudo, determinado a taxa de mortalidade em 3,1\%.

Tabela 14. Média, desvio padrão e parâmetros fitossociológicos (freqüência absoluta Fa; freqüência relativa - Fr; densidade absoluta - Da; densidade relativa Dr) dos indivíduos amostrados no estrato de regeneração (>0,3m e $<2 \mathrm{~m}$ ) da área B (área de estudo em Iracemápolis, SP).

\begin{tabular}{|c|c|c|c|c|c|}
\hline Espécie & $\begin{array}{l}\text { Média } \pm \text { Desvio } \\
\text { padrão }\end{array}$ & $\mathrm{Fa}(\%)$ & $\operatorname{Fr}(\%)$ & $\begin{array}{c}\mathrm{Da} \\
\text { (ind.m }\end{array}$ & $\operatorname{Dr}(\%)$ \\
\hline $\begin{array}{l}\text { Alectryon cf tomentosum } \\
\text { Radlk }\end{array}$ & $0,77 \pm 0,92$ & 33,33 & 33,33 & 0,76 & 43,40 \\
\hline $\begin{array}{l}\text { Nectandra megapotamica } \\
\text { (Spreng.) Mez. }\end{array}$ & $0,20 \pm 0,42$ & 13,33 & 13,33 & 0,20 & 11,32 \\
\hline $\begin{array}{l}\text { Leucaena leucocephala } \\
\text { (Lam.) de Wit }\end{array}$ & $0,17 \pm 0,53$ & 10,00 & 10,00 & 0,17 & 9,43 \\
\hline $\begin{array}{l}\text { Piper gaudichaudianum } \\
\text { Kunth. }\end{array}$ & $0,10 \pm 0,22$ & 6,67 & 6,67 & 0,10 & 5,66 \\
\hline $\begin{array}{l}\text { Centrolobium tomentosum } \\
\text { Guill. ex Benth. }\end{array}$ & $0,17 \pm 0,53$ & 3,33 & 3,33 & 0,17 & 9,43 \\
\hline $\begin{array}{l}\text { Tabebuia chrysotricha } \\
\text { (Mart. ex DC.) Standl. }\end{array}$ & $0,20 \pm 0,42$ & 3,33 & 3,33 & 0,07 & 3,77 \\
\hline $\begin{array}{l}\text { Tibouchina sellowiana } \\
\text { (Cham.) Cogn }\end{array}$ & $0,10 \pm 0,32$ & 3,33 & 3,33 & 0,03 & 1,89 \\
\hline $\begin{array}{l}\text { Tecoma stans } \\
\text { (L.) Juss.ex.H.B.K }\end{array}$ & $0,10 \pm 0,32$ & 3,33 & 3,33 & 0,03 & 1,89 \\
\hline $\begin{array}{l}\text { Tabebuia roseo-alba } \\
\text { (Ridl.) Sand. }\end{array}$ & $0,10 \pm 0,32$ & 3,33 & 3,33 & 0,03 & 1,89 \\
\hline $\begin{array}{l}\text { Murraya paniculata } \\
\text { (L.) Jack }\end{array}$ & $0,10 \pm 0,32$ & 3,33 & 3,33 & 0,03 & 1,89 \\
\hline $\begin{array}{l}\text { Lonchocarpus muehlbergianus } \\
\text { Hassl. }\end{array}$ & $0,10 \pm 0,32$ & 3,33 & 3,33 & 0,03 & 1,89 \\
\hline $\begin{array}{l}\text { Helicteres ovata } \\
\text { Lam. }\end{array}$ & $0,10 \pm 0,32$ & 3,33 & 3,33 & 0,03 & 1,89 \\
\hline $\begin{array}{l}\text { Enterolobium contortisiliquum } \\
\text { (Vell.) Morong. }\end{array}$ & $0,10 \pm 0,32$ & 3,33 & 3,33 & 0,03 & 1,89 \\
\hline $\begin{array}{l}\text { Cestrum laevigatum } \\
\text { Schltdl. }\end{array}$ & $0,10 \pm 0,32$ & 3,33 & 3,33 & 0,03 & 1,89 \\
\hline $\begin{array}{l}\text { Astronium graveolens } \\
\text { Jacq. }\end{array}$ & $0,10 \pm 0,32$ & 3,33 & 3,33 & 0,03 & 1,89 \\
\hline
\end{tabular}




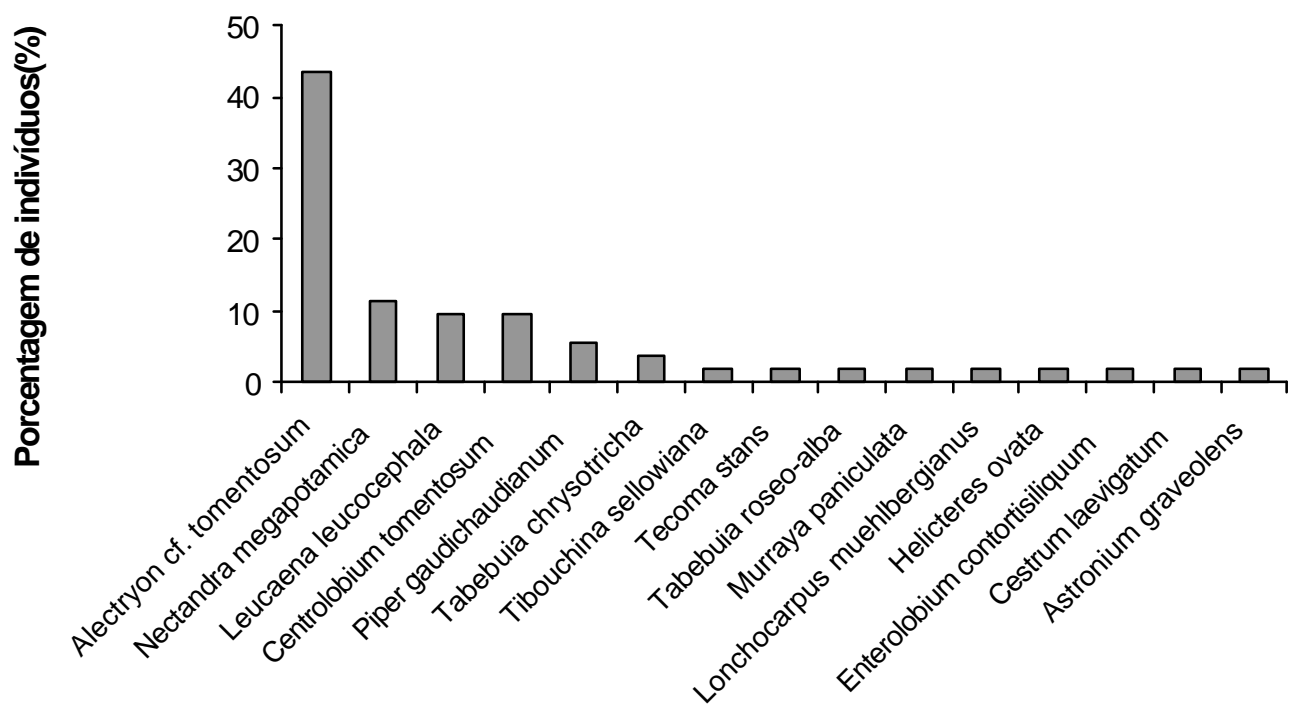

Figura 16 - Porcentagem de indivíduos por espécies amostradas no estrato de regeneração da área B (área de estudo em Iracemápolis, SP).

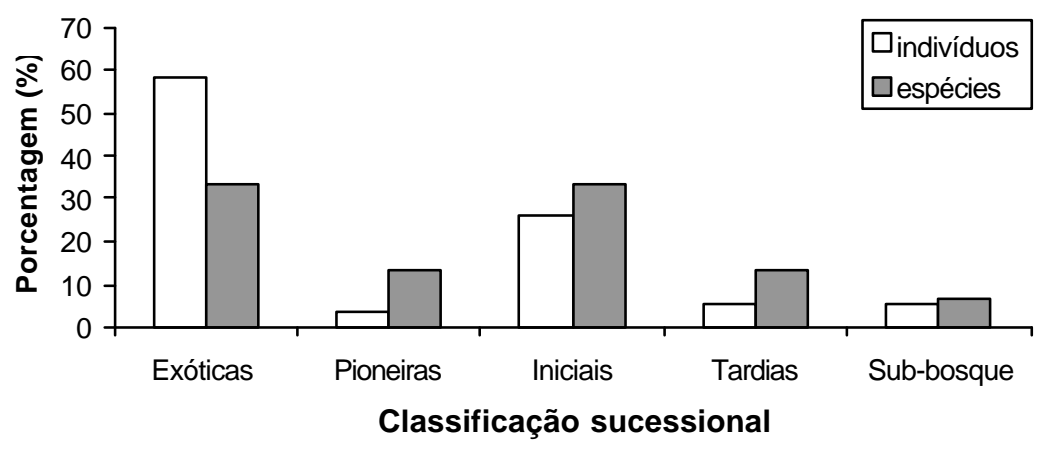

Figura 17 - Porcentagem dos indivíduos e espécies amostrados no estrato de regeneração da área $\mathrm{B}$, agrupados por classe sucessional (área de estudo em Iracemápolis, SP).

Leucaena leucocepha e Tecoma stans são espécies comuns ao estrato de regeneração e aquelas encontradas na chuva de sementes. Leucaena leucocepha 
aparece ainda, entre as espécies amostradas no banco de sementes, nas duas estações de coleta, e no estrato de regeneração.

A média de altura dos indivíduos amostrados na segunda estação de coleta foi superior ao apresentado na primeira estação (Figura 14). Agrupando os indivíduos por classificação sucessional é possível perceber que este incremento em altura foi superior em espécies pioneiras (Figura 18).

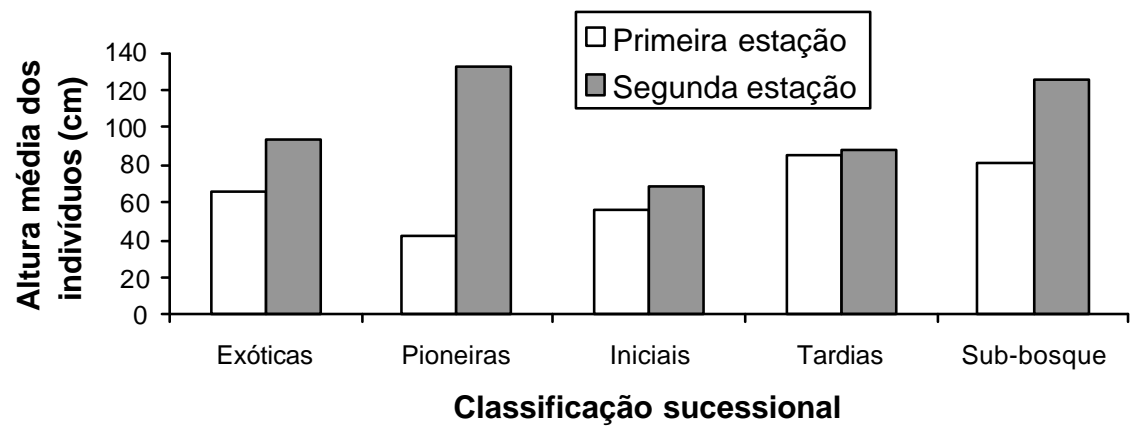

Figura 18 - Altura média dos indivíduos agrupada por classe sucessional, na priemra estação de coleta (janeiro de 2001) e na segunda estação de coleta (janeiro de 2002), na área B (área de estudo em Iracemápolis, SP).

\subsection{Discussão}

A escolha em analisar o estrato de regeneração, como um dos indicadores, está associado ao fato de que estes representam o potencial ou a capacidade de regeneração da comunidade (Laska, 1997; Oliveira, 1999), que é uma das questões fundamentais para o estabelecimento de práticas adequadas de conservação, manejo e restauração de áreas (Rodrigues, 1999).

Através dos resultados obtidos para o estrato de regeneração foi possível verificar a presença de indivíduos jovens nas duas áreas de estudo. Entretanto, existem profundas diferenças na composição do estrato de regeneração entre as áreas. 
$\mathrm{A}$ área $\mathrm{A}$ apresentou riqueza de espécies e densidade de indivíduos inferiores à obtida na área B. Este resultado pode estar sendo determinado por diferentes condicionantes.

As sementes presentes no solo, bem como aquelas recentemente dispersas, contribuem para o desenvolvimento da vegetação (Guariguata \& Osterg, 2001). Quando este processo não ocorre, pode estar havendo falha em algumas destas vias de entradas, ou a limitação no recrutamento dos indivíduos posteriormente a formação do banco e a dispersão de sementes.

Como visto nos capítulos anteriores, apesar dos dados do banco de sementes indicarem a presença de espécies arbustivas-arbóreas (ainda que em baixa quantidade e diversidade) na área $A$, o estrato de regeneração apresenta baixíssima riqueza (2 espécies). Provavelmente estas sementes, presentes no banco, não estão sendo estimuladas para germinar como indivíduos jovens, permanecendo na condição de banco de sementes. Este resultado demonstra uma quebra no processo de regeneração, possivelmente na fase de estabelecimento das plântulas. Desta forma o potencial do banco e possivelmente da chuva de sementes não está sendo realizado.

Numa dada área a germinação das sementes in situ é limitada por condições bióticas e abióticas.

Como fatores bióticos, podemos citar a interação entre as espécies que ocupam o dossel e as emergentes, uma vez que a colonização do sub-bosque é determinada pelo conjunto de árvores adultas (George \& Bazzaz, 1999b). Através da influência diferencial na emergência, estabeleciemento, crescimento e sobrevivência das plântulas, o filtro formado pelas espécies de dossel condiciona quais indivíduos, de quais espécies irão alcançar o estrato superior (George \& Bazzaz, 1999a).

No caso de áreas restauradas, as espécies estabelecidas no dossel atuam como catalizadores (Lugo, 1997), facilitando o estabelecimento de novas espécies, através de sua influência no microclima do sub-bosque, fertilidade do solo, supressão de espécies invasoras e provisão de alimentos e habitat para fauna (Parrota, 1995; Parrota et al., 1997b; Power, 1997). Os indivíduos já estabelecidos contribuem ainda na chuva e no banco de sementes autôctone.

$\mathrm{Na}$ área A foi utilizado um menor número de espécies no plantio (35 espécies) em comparação ao utilizado na área B (140 espécies). É possível que tal fato esteja 
determinando a diversidade de espécies em regeneração, em função desta restrição na riqueza inicial.

Adicionalmente, na área $A$, em alguns trechos o dossel é dominado pela espécie Leucaena leucocephala, o que pode estar promovendo o grande número de indivíduos desta mesma espécie, encontrados também no estrato de regeneração. $A$ presença massiva desta espécie está associada seu caráter agressivo e invasor, alta produção de frutos e possível ação alelopática (Parrota, 1999).

A presença da Leucena pode ainda estar impedindo o recrutamento de novos indivíduos provinientes do banco e da chuva de sementes. Jurado (1998) estudando o estabelecimento de plântulas sob um plantação de Leucaena, no noroeste do México, constatou que a germinação era muito baixa para todas espécies, com exceção da própria Leucena.

Outra interação biótica que pode estar ocorrendo em ambas as áreas é a de predação e parasitismo das sementes pré e pós dispersão. A predação das sementes pode ser considerado um dos maiores impedimentos a regeneração das sementes em áreas tropicais (Terborgh et al., 1993).

Como questões físicas, as características do solo como grau de acidez e compactação são de fundamental importância para 0 desenvolvimento e estabelecimento das plântulas. Através do histórico das áreas estudadas é possível verificar que em nenhuma destas o solo apresenta boa estrutura e composição para o desenvolvimeto de vegetação. A área $A$ era utilizada para despejo de entulho e material de construção, o que tornou o solo bastante compactado. Já na área $\mathrm{B}$, a intensa atividade agrícola pode ter levado ao empobrecimento do solo.

Condições de luz podem ainda estar determinado as espécies selecionadas no sub-bosque das áreas uma vez que o dossel limita a qualidade e a intensidade de luz que atinge os estratos inferiores, como afirmado anteriormente.

Leucaena leucochephala é a única espécie presente tanto no banco de sementes quanto no estrato de regeneração, para as duas áreas. Isto comprova, mais uma vez, sua agressividade e poder de invasão.

O baixo número de espécies em comum entre o banco de sementes e as espécies em regeneração pode também ser explicado pelo fato dos indivíduos formadores de banco de sementes não serem capaz de germinar sob dossel fechado. 
Intervenções periódicas na área A com desbastes e cortes no sub-bosque, com fins de limpeza e segurança do local, certamente afetam os resultados encontrados. Este manejo pode estar contribuíndo para a baixa riqueza e diversidade obtidos, uma vez que a retirada do indivíduos não é seletiva. Este fato pode também ser a causa da maior mortalidade encontrada na área.

A diferença de idade entre os plantios nas duas áreas (10 anos na área A e 14 anos na área B) certamente contribui para os resultados encontradas na composição de espécies e na densidade e indivíduos. Espera-se que uma área de maior idade apresente maior número de indivíduos e riqueza de espécies.

A pouca idade dos plantios pode implicar no fato de algumas espécies estarem em período pré-reprodutivo, o que limita a disponibilidade de sementes para a regeneração nestas áreas.

Os resultados obtidos para área $\mathrm{B}$, demonstram que a regeneração está ocorrendo com relativo sucesso. Comparativamente, num estudo conduzido por Souza (2000), no Pontal do Paranapanema, em três áreas de diferentes idades de plantio, (1988,1989 e 1993) foram encontradas 16 espécies, nas duas áreas de maior idade de restauração (11 e 10 anos) e nenhuma espécie na área com 6 anos. Já em termos de densidade, foram encontrados 0,56 indivíduos. $\mathrm{m}^{-2}$ na área de 11 anos; 0,35 indivíduos. $\mathrm{m}^{-2}$ na área de 10 anos e nenhum indivíduo na área de 6 anos. Neste levantamento foram avaliados os indivíduos com altura superior a $50 \mathrm{~cm}$ e circunferência altura do peito abaixo de $15 \mathrm{~cm}$, numa área total igual a 169,56 $\mathrm{m}^{2}$ $\left(75,36 \mathrm{~m}^{2}\right.$ para área de 11 anos; $37,68 \mathrm{~m}^{2}$ para área de 10 anos; $56,52 \mathrm{~m}^{2}$ para área de 6 anos).

Apesar da diferença nos critérios de inclusão dos indivíduos e da área total amostrada, podemos observar que a riqueza e densidade de espécies encontradas nas áreas A e B, do presente estudo são superiores as registradas por Souza, 2000.

Em outro estudo conduzido por Parrota e Knowles (1999) em áreas restauradas de 13 e 9 anos com diferentes metodologias em uma floresta primária na Amazônia, foram encontradas médias de densidade variando entre 1,55 e 3,47 indivíduos. $\mathrm{m}^{-2}$. O número de espécies encontrado variou entre 40 a 157 espécies conforme o estado de regenração da área. Neste estudo as áreas amostradas estiveram entre 600 e 2.500 $\mathrm{m}^{2} \mathrm{e}$ os indivíduos amostrados apresentavam altura inferior a $2 \mathrm{~m}$. 
Gromboni-Garatini (1999) estudando uma floresta estacional semidecidual no interior do estado de São Paulo encontrou uma densidade média de 2,65 indivíduos.m ${ }^{2}$ e um total de 56 espécies. Á area amostral neste estudo totalizou $218,75 \mathrm{~m}^{2}$ sendo que o critério de inclusão de indivíduos selecionava aqueles com altura superior a 0,5m e inferior a $4,0 \mathrm{~m}$.

É importante ressaltar a discussão já comentada no capítulo 1, sobre a questão da comparação entre áreas. Estes paralelos devem ser entendidos com um indício da trajetória dos projetos de restauração, e não como garantia de seu sucesso, uma vez que a evolução de cada sistema pode se dar de diferentes maneiras. Isto é ainda mais crítico para áreas como a Amazônia onde o histórico de ocupação e a vizinhança são extremamente diferentes do encontrado no sudeste do Brasil.

O maior incremento em altura se deu em espécies tipicamente pioneiras. Este resultado era esperado uma vez que estas espécies têm por estratégia altas taxa de crescimento, produção de frutos e baixa longevidade, tendendo a ser "r estrategistas" ou "r selecionadas" (sensu Pianka, 1970).

A dominância de uma únca espécies no sub-bosque de áreas restauradas foi encontrada também em outros estudos. Tucker \& Murphy (1997), analisando o efeito da restauração sobre o recrutamento de novas espécies, em 4 áreas de diferentes idades de plantio e uma área contole, observaram vários graus de dominância por uma ou poucas espécies em todas as áreas.

Martinez-Ramos \& Soto Castro (1993) indicam que a dominância pode ser um reflexo da predação, condições ambientais, flutuações sazonais e anuais na produção de sementes, intensidade de frugivoria e chuva de sementes.

A grande presença da espécie Alectrion cf. tomentosum no sub-bosque da área B pode implicar numa alteração do desenvolvimento da vegetação, já que muitos desses indivíduos podem ser recrutados para formar o dossel. E caso esse potencial venha a se realizar haverá uma mudança na composição do dossel no sentido de formar uma comunidade dominada por esta única espécie.

Entretanto, a tendência a dominância e os possíveis efeitos na estrutura da comunidade a longo termo são imprevisíveis, e o grau de dominância pode, por fim, vir a tornar-se apenas, uma espécies mais freqüente em uma floresta diversa e madura (Tucker \& Murphy, 1997) 
A presença de espécies pioneiras e de fases iniciais e intermediárias de sucessão no banco e principalmente ra chuva de sementes pode garantir que o desenvolvimento da vegetação seguirá o processo natural de regeneração.

A ausência de espécies finais de sucessão pode indicar que estes indivíduos ainda não estão se reproduzindo quer por falta de agente polinizador ou em função da idade dos plantios, estando os indivíduos ainda em estágio imaturo de reprodução.

Outro aspecto importante a ser comentado é a questão da metodologia empregada. A observação de outras espécies e formas de vida como lianas, não registradas pelo levantamento nos estrato de regeneração, parece indicar que talvez o método de parcelas não seja o mais apropriado para a caracterização do sub-bosque nestas áreas. Possívelmente, um caminhamento aleatório, com determinação do esforço amostral seria mais eficiente no sentido de amostrar uma maior área. Entretanto, a maioria dos estudos com levantamento do estrato de regeneração e de plântula utiliza o método de parcelas, pela facilidade logística e para fins estatíiticos.

\subsection{Conclusões}

- O estrato de regeneração da área $A$ apresentou-se dominado por uma única espécie, Leucaena leucocephala;

- Na área B, a maior porcentagem de espécies encontrada no estrato de regenerção foi caracterizada como exótica;

- Espécies pioneiras apresentaram um maior incremento na altura entre os indivíduos amostrados na área $B$;

- A baixa similaridade encontrada entre os indivíduos germinados nas amostras do banco, e das espécies coletadas na chuva de sementes com os indivíduos amostrados no estrato de regeneração parece indicar uma mudança na estrutura e composição da comunidade ao longo da sucessão;

- O levantamento do estrato de regeneração apresentou importantes informações para a avaliação do processo de regeneração nas áreas restauradas; 
- Aspectos do estrato de regeneração como o número de espécies, a densidade de indivíduos e grupo sucessional a que pertencem fornecem bons parâmentros para o monitoramento das áreas restauradas;

- O total de informações, a simplicidade do procedimento e a objetividade do dados obtidos para o levantamento do estrato de regeneração sugerem que este possa ser o melhor indicador para a avaliação de sucesso de projetos de restauração nestas áreas, dentre os três sugeridos neste estudo. 


\section{CONCLUSÕES GERAIS}

O objetivo deste estudo foi avaliar o que nós consideramos como aspectos principais da comunidade vegetal, que poderiam influenciar a restauração de áreas. Adimitimos que sem a recuperação de determinados atributos do sistema, podemos esperar que algumas funções dificilmente serão reestabelecidas.

Entendemos, como outros autores, que a restauração na prática pode envolver objetivos múltiplos e sequênciais, tal com verificar o desenvolvimento do plantio (ex. crescimento e mortalidade das mudas); monitorar a restauração estrutural da comunidade (ex. aumento na riqueza de espécies); e por fim, verificar se a ligação entre estrutura e função da comunidade foi estabelecida.

Partimos, então, para a análise de aspectos estruturais da comunidade, que incluíram avaliações do banco de sementes, da chuva de sementes e do estrato de regeneração em áreas restauradas, buscando indicadores para acessar a capacidade de regeneração nestas áreas.

Através da composição e da abundância de sementes presentes no banco do solo, verificamos que existe apenas um pequeno grupo de espécies que poderá germinar, contribuindo para a regeneração da área. Esta restrição do número de sementes é principlamente causada pela baixa longevidade e ausência de dormência da maioria das espécies tropicais que ficam pouco tempo disponível no banco.

Grande parte dos indivíduos presentes no banco pertence a espéceis herbáceas invasoras, o que determina a baixa similaridade encontrada entre a flora do banco e as espécies estabelecidas no dossel.

Desta maneira, o papel desempenhado pela chuva de sementes para a regeneração nestas áreas, torna-se fundamental à medida que através da dispersão, 
novas espécies podem colonizar estes ambientes, fundando diferentes populações.

O fluxo de propágulos pode ser influênciado por diversos fatores como o tamanho da área plantada, o tipo matriz a qual está inserida, a presença e eficiência de agentes dispersores, entre outros.

Áreas restauradas no interior de São Paulo, freqüentemente, estão em pequenos fragmentos isoladas por cultura canaviera, distantes de área naturais as quais possam servir como fonte de sementes. Este contexto explica o porquê da maior porcentagem dos indivíduos depositados nos coletores terem origem autotóctone.

Esta característica pode ser considerada um problema para a conservação e manutenção das espécies raras, por ocasião da redução da viabilidade dos indivíduos resultantes de cruzamentos co-sangüineos.

O estrato de regeneração é resultante do recrutamento dos indivíduos do banco ou da chuva de sementes. Entretanto, muitas vezes este potencial não é realizado em virtude de limitações no estabelecimento dos indivíduos. Estas barreiras incluem aspectos bióticos como predação e parasitismo, e abióticos como condições físicas do solo. Por outro lado, em muitas situações, o que ocorre é a própria limitação nos estoque de sementes a serem recrutadas tanto no banco quanto na chuva de sementes.

Entre os indicadores selecionados para 0 monitoramento das áreas restauradas, o estrato de regeneração foi o que fornece informações mais precisas sobre o desenvolvimento destes projetos. Os indivíduos jovens regenerantes representam uma estrutura e composição do banco e da chuva de sementes passados. Indicam ainda a possível formação e estrutura futura do dossel.

Adicionalmete, o estrato de regeneração é o parâmetro mais facilmente acessado e interpretado, o que favorece sua utilização para a avaliação de sucesso de projetos de restauração.

A ausência de similaridade entre a chuva, o banco e o estrato de regeneração parecem indicar que a evolução deste ecossistema contará com uma mudança em sua composição.

Os resultados deste estudo indicam que na área $B$ foi possível criar uma ambiente favorável à regeneração natural e que na área $A$ esta regeneração pode estar sendo limitada. As possíveis causas desta limitação passam pela idade, tamanho do plantio, o número de espécies utilizado no projeto de restauração, intensidade de 
manejo anterior, qualidade do solo e localização da área na paisagem. Uma provável razão a ser considerada nesta análise diz respeito ao potencial invasor e à atuação alelopática de uma espécie exótica bastante comum nesta área, a Leucena leuocephala.

O estudo indica ainda que para assegurar a riqueza de espécies e o sucesso da restauração nestas áreas faz-se necessário a intervenção, quer pela introdução de espécies, controle da Leucena, criação de poleiros artificiais ou a indução de clareiras, como sugerido para outras áreas. 
ANEXOS 


\section{ANEXO A}

Tabela 1. Lista das espécies usadas na restauração da área $A$ (área de estudo em Piracicaba, SP), de acordo com a família e categoria sucessional.

\begin{tabular}{|c|c|c|c|}
\hline Família & Espécie & Autor & Grupo ecológico \\
\hline Anacardiaceae & Schinus terebinthifolius & Raddi. & Pioneira. \\
\hline Apocynaceae & Aspidosperma polyneuron & Müll. Arg. & Secundária tardia. \\
\hline & Aspidosperma ramiflorum & Müll.Arg. & Secundária tardia. \\
\hline Bignoniaceae & Tabebuia chrysotricha & (Mart. ex DC.) Standl. & Secundária. \\
\hline Bombacaceae & Chorisia speciosa & A.St.-Hill & Secundária inicial. \\
\hline Boraginaceae & Cordia superba & Cham. & Secundária tardia. \\
\hline Caesalpinaceae & Hymenaea courbaril & L. & Clímax. \\
\hline Cecropiaceae & Cecropia pachystachya & Trec. & Pioneira. \\
\hline Clusiaceae & $\begin{array}{l}\text { Calophyllum brasiliensis } \\
\text { Cytharexyllum myrianthum }\end{array}$ & $\begin{array}{l}\text { Camb. } \\
\text { Cham. }\end{array}$ & $\begin{array}{l}\text { Secundária inicial. } \\
\text { Pioneira. }\end{array}$ \\
\hline Euphorbiaceae & Alchornea iricurana & Casar. & Secundária inicial. \\
\hline & Alchornea triplinervia & (Spreng.) Müll. Arg. & Pioneira. \\
\hline & Croton floribundus & (L.) Spreng. & Pioneira. \\
\hline & Croton urucurana & Baill. & Pion \\
\hline Fabaceae & $\begin{array}{l}\text { Centrolobium tomentosum } \\
\text { Machaerium nictitans }\end{array}$ & $\begin{array}{l}\text { Guill. ex Benth. } \\
\text { (Vell.) Benth. }\end{array}$ & $\begin{array}{l}\text { Secundária inicial. } \\
\text { Clímax. }\end{array}$ \\
\hline & Myroxylon peruiferum & L. f. & Secundária tardia. \\
\hline & Ormosia minor & Vogel & Clímax. \\
\hline Lauraceae & Cryptocarya moschata & Ness. & Clímax. \\
\hline Lecythidaceae & $\begin{array}{l}\text { Cariniana estrellensis } \\
\text { Cariniana legalis }\end{array}$ & $\begin{array}{l}\text { (Raddi) Kuntze. } \\
\text { (Mart.) Kuntze. }\end{array}$ & $\begin{array}{l}\text { Secundária tardia. } \\
\text { Secundária tardia. }\end{array}$ \\
\hline Meliaceae & Cedrela fissilis & Vell. & Secundária inicial. \\
\hline Mimosaceae & $\begin{array}{l}\text { Anadenanthera macrocarpa } \\
\text { Enterolobium timbouva } \\
\text { Inga vera }\end{array}$ & $\begin{array}{l}\text { Benth. } \\
\text { (Mart.) Mesquita } \\
\text { Willd. }\end{array}$ & $\begin{array}{l}\text { Secundária inicial. } \\
\text { Secundária inicial. } \\
\text { Clímax. }\end{array}$ \\
\hline & Piptadenia gonoacantha & (Mart.) Macbr. & Secundária inicial. \\
\hline Myrtaceae & Psidium cattheianum & Sabine. & Secundária inicial. \\
\hline Phytolaccaceae & Gallesia gorazema & (Spreng.) Harms. & Pioneira. \\
\hline Rutaceae & $\begin{array}{l}\text { Ezenbeckia leiocarpa } \\
\text { Zanthoxylum riedelianum }\end{array}$ & $\begin{array}{l}\text { Engl. } \\
\text { Engl. }\end{array}$ & $\begin{array}{l}\text { Clímax. } \\
\text { Pioneira. }\end{array}$ \\
\hline Sapotaceae & Chrysophyllum gonocarpo & (Mart. ex Eichl.)Engl. & Pioneira. \\
\hline Tiliaceae & Luehea divaricata & Mart. & Secundária inicial. \\
\hline Ulmaceae & Trema micrantha & (L.) Blume. & Pioneira. \\
\hline Verbenaceae & Vitex megapotamica & (Spreng.) Mold. & Secundária tardia. \\
\hline
\end{tabular}


Tabela 2. Lista das espécies usadas na restauração da área B (área de estudo em Iracemápolis, SP), de acordo com a família e categoria sucessional.

\begin{tabular}{|c|c|c|c|}
\hline \multirow{2}{*}{$\begin{array}{l}\text { Família } \\
\text { Anacardiaceae }\end{array}$} & Espécie & Autor & Grupo ecológico \\
\hline & $\begin{array}{l}\text { Astronium graveolens } \\
\text { Lithraea molleoides } \\
\text { Myracrodruon urundeuva } \\
\text { Schinus molle } \\
\text { Schinus terebinthifolius } \\
\text { Spondias lutea }\end{array}$ & $\begin{array}{l}\text { Jacq. } \\
\text { (Vell.) Engl. } \\
\text { Allemão } \\
\text { L. } \\
\text { Raddi. } \\
\text { L. }\end{array}$ & $\begin{array}{l}\text { Secundária tardia. } \\
\text { Secundária inicial. } \\
\text { Clímax. } \\
\text { Secundária inicial. } \\
\text { Pioneira. } \\
\text { Frutifera }\end{array}$ \\
\hline Annonaceae & $\begin{array}{l}\text { Annona cacans } \\
\text { Rollinia sulcosa }\end{array}$ & $\begin{array}{l}\text { Warm. } \\
\text { (Jacq.) Baill. }\end{array}$ & $\begin{array}{l}\text { Secundária inicial. } \\
\text { Secundária inicial. }\end{array}$ \\
\hline Apocynaceae & $\begin{array}{l}\text { Aspidosperma } \\
\text { cylindrocarpon }\end{array}$ & Müll.Arg. & Secundária inicial. \\
\hline \multirow{4}{*}{$\begin{array}{l}\text { Araucariaceae } \\
\text { Arecaceae }\end{array}$} & $\begin{array}{l}\text { Aspidosperma ramiflorum } \\
\text { Araucaria angustifolia }\end{array}$ & $\begin{array}{l}\text { Müll.Arg. } \\
\text { (Bertol.).Kuntze }\end{array}$ & $\begin{array}{l}\text { Secundária tardia. } \\
\text { Exótica. }\end{array}$ \\
\hline & $\begin{array}{l}\text { Archantophoenix alexandrae } \\
\text { Euterpe edulis } \\
\text { Livistona chinensis }\end{array}$ & $\begin{array}{l}\text { Mart. (jacq.) R. Br. } \\
\text { (N. J. Jacquin) R. Brown ex } \\
\text { Mart. }\end{array}$ & $\begin{array}{l}\text { Secundária tardia. } \\
\text { Clímax. } \\
\text { Secundária inicial. }\end{array}$ \\
\hline & Mauritia vinifera & Mart. & Secundária inicial. \\
\hline & $\begin{array}{l}\text { Syagrus oleracea } \\
\text { Syagrus romanzoffiana }\end{array}$ & $\begin{array}{l}\text { Mart.Becc. } \\
\text { (Cham.) Glassman. }\end{array}$ & $\begin{array}{l}\text { Secundaria inicial. } \\
\text { Secundária inicial. }\end{array}$ \\
\hline Bignoniaceae & $\begin{array}{l}\text { Jacaranda mimosaefolia } \\
\text { Parmentiera cereifera } \\
\text { Tabebuia chrysotricha } \\
\text { Tabebuia heptaphylla } \\
\text { Tabebuia pentaphylla }\end{array}$ & $\begin{array}{l}\text { D.Don. } \\
\text { Seem. } \\
\text { (Mart. ex DC.) Standl. } \\
\text { (Vell.) Tol. } \\
\text { (L.) Hemsl. }\end{array}$ & $\begin{array}{l}\text { Secundária inicial. } \\
\text { Secundária inicial. } \\
\text { Secundária. } \\
\text { Secundária. } \\
\text { Secundária. }\end{array}$ \\
\hline Bombacaceae & $\begin{array}{l}\text { Ceiba erianthus } \\
\text { Ceiba pentandra } \\
\text { Chorisia speciosa } \\
\text { Pachira aquatica } \\
\text { Pseudobombax grandiflorum }\end{array}$ & $\begin{array}{l}\text { (Cav.) K.Schum } \\
\text { (L.) Gaertn. } \\
\text { A.St.-Hill } \\
\text { Aubl. } \\
\text { (Cav.) A. Rob. }\end{array}$ & $\begin{array}{l}\text { Secundária tardia. } \\
\text { Secundária tardia. } \\
\text { Secundária inicial. } \\
\text { Exótica } \\
\text { Secundária inicial. }\end{array}$ \\
\hline $\begin{array}{l}\text { Boraginaceae } \\
\text { Boraginaceae }\end{array}$ & $\begin{array}{l}\text { Cordia ecalyculata } \\
\text { Cordia myxa } \\
\text { Cordia superba } \\
\text { Cordia trichotoma }\end{array}$ & $\begin{array}{l}\text { Vell. } \\
\text { L. } \\
\text { Cham. } \\
\text { (Vell.) Arrab.ex Steud. }\end{array}$ & $\begin{array}{l}\text { Secundária inicial. } \\
\text { Secundária inicial. } \\
\text { Secundária tardia. } \\
\text { Secundária. }\end{array}$ \\
\hline \multirow[t]{2}{*}{ Caesalpinaceae } & $\begin{array}{l}\text { Bauhinia forficata } \\
\text { Caesalpinia leiostachya } \\
\text { Caesalpinia echinata } \\
\text { Caesalpinia pluviosa var } \\
\text { peltophoroides }\end{array}$ & $\begin{array}{l}\text { Link. } \\
\text { (Benth.) Duke } \\
\text { Lam. } \\
\text { Speg. }\end{array}$ & $\begin{array}{l}\text { Pioneira. } \\
\text { Secundária tardia. } \\
\text { Clímax. } \\
\text { Secundária tardia. }\end{array}$ \\
\hline & $\begin{array}{l}\text { Cassia carnaval } \\
\text { Cassia fistula } \\
\text { Cassia grandis } \\
\text { Copaifera langsdorffii } \\
\text { Holocalyx balansae } \\
\text { Hymenaea courbaril } \\
\text { Peltophorum dubium } \\
\text { Pterogyne nitens } \\
\text { Schizolobium parahybum } \\
\text { Tamarindus indica }\end{array}$ & $\begin{array}{l}\text { Speg. } \\
\text { L. } \\
\text { L.f. } \\
\text { Desf. } \\
\text { M. Micheli } \\
\text { L. } \\
\text { (Spreng.) Taub. } \\
\text { Tul. } \\
\text { (Vell.) Blake. } \\
\text { L. }\end{array}$ & $\begin{array}{l}\text { Secundária inicial. } \\
\text { Secundária inicial. } \\
\text { Secundária inicial. } \\
\text { Secundária tardia. } \\
\text { Secundária tardia. } \\
\text { Clímax. } \\
\text { Secundária inicial. } \\
\text { Secundária inicial. } \\
\text { Pioneira. } \\
\text { Frutífera. }\end{array}$ \\
\hline Caricaceae & Jacaratia spinosa & (Aubl.) A DC. & Pioneira. \\
\hline
\end{tabular}


Tabela 2. Lista das espécies usadas na restauração da área B (área de estudo em Iracemápolis, SP), de acordo com a família e categoria sucessional .

\begin{tabular}{|c|c|c|c|}
\hline Família & Espécie & Autor & Grupo ecológico \\
\hline Cecropiaceae & Cecropia pachystachya & Trec. & Pioneira. \\
\hline Chrysobalanacea€ & Moquila tomentosa & & Frutífera \\
\hline Clusiaceae & $\begin{array}{l}\text { Calophyllum brasiliensis } \\
\text { Garcinia conchinchinensis }\end{array}$ & $\begin{array}{l}\text { Camb. } \\
\text { (Mart.) Baehni Pennington }\end{array}$ & $\begin{array}{l}\text { Secundária inicial. } \\
\text { Frutífera }\end{array}$ \\
\hline Combretaceae & Terminalia argentea & Mart. & Secundária inicial. \\
\hline Dilleniaceae & Dillenia indica & L. & Frutífera \\
\hline Euphorbiaceae & $\begin{array}{l}\text { Alchornea iricurana } \\
\text { Croton floribundus } \\
\text { Hevea brasiliensis } \\
\text { Scodia dictiocarpa }\end{array}$ & 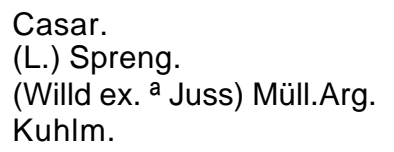 & $\begin{array}{l}\text { Secundária inicial } \\
\text { Pioneira. } \\
\text { Secundária tardia. } \\
\text { Secundária tardia. }\end{array}$ \\
\hline Fabaceae & $\begin{array}{l}\text { Centrolobium tomentosum } \\
\text { Dalbergia nigra } \\
\text { Dalbergia variabilis } \\
\text { Erythrina corallodendron }\end{array}$ & $\begin{array}{l}\text { Guill. Ex Benth. } \\
\text { (Vell.) Fr. All. Ex Benth. } \\
\text { Vogel } \\
\text { L. }\end{array}$ & $\begin{array}{l}\text { Secundária inicial. } \\
\text { Secundária tardia. } \\
\text { Secundária tardia. } \\
\text { Secundária inicial. }\end{array}$ \\
\hline Fabaceae & $\begin{array}{l}\text { Erythrina crista-galli } \\
\text { Erythrina speciosa } \\
\text { Erythrina velutina } \\
\text { Erythrina vena } \\
\text { Lonchocarpus } \\
\text { muehlbergianus }\end{array}$ & $\begin{array}{l}\text { L. } \\
\text { Andrews. } \\
\text { Willd. } \\
\text { Vell. } \\
\text { Hassl. }\end{array}$ & $\begin{array}{l}\text { Secundária tardia. } \\
\text { Secundária tardia. } \\
\text { Secundária tardia. } \\
\text { Secundária tardia. } \\
\text { Secundária inicial. }\end{array}$ \\
\hline & Myroxylon peruiferum & L. f. & Secundária tardia. \\
\hline & $\begin{array}{l}\text { Plathymiscium floribundus } \\
\text { Poecilanthe parviflora }\end{array}$ & $\begin{array}{l}\text { Vogel } \\
\text { Benth. }\end{array}$ & $\begin{array}{l}\text { Secundária tardia. } \\
\text { Secundária. }\end{array}$ \\
\hline & $\begin{array}{l}\text { Pterocarpus violaceus } \\
\text { Tipuana tipu }\end{array}$ & $\begin{array}{l}\text { Vog. } \\
\text { (Benth.) Kuntze }\end{array}$ & $\begin{array}{l}\text { Secundária inicial. } \\
\text { Exótica }\end{array}$ \\
\hline Flacourtiaceae & $\begin{array}{l}\text { Casearia obliqua } \\
\text { Casearia sylvestris }\end{array}$ & $\begin{array}{l}\text { Spreng. } \\
\text { Sw. }\end{array}$ & $\begin{array}{l}\text { Secundária tardia. } \\
\text { Pioneira. }\end{array}$ \\
\hline Lauraceae & $\begin{array}{l}\text { Cryptocarya moschata } \\
\text { Nectandra megapotamica } \\
\text { Ocotea corymbosa } \\
\text { Ocotea pretiosa }\end{array}$ & $\begin{array}{l}\text { Ness. } \\
\text { (Spreng.) Mez } \\
\text { (Meisn.) Mez. } \\
\text { Benth. \& Hook. F. }\end{array}$ & $\begin{array}{l}\text { Clímax. } \\
\text { Secundária inicial. } \\
\text { Secundária inicial. } \\
\text { Clímax. }\end{array}$ \\
\hline Lecythidaceae & $\begin{array}{l}\text { Cariniana estrellensis } \\
\text { Cariniana legalis } \\
\text { Gustavia augusta } \\
\text { Lecythis pisonis }\end{array}$ & $\begin{array}{l}\text { (Raddi) Kuntze. } \\
\text { (Mart.) Kuntze. } \\
\text { L. } \\
\text { Camb. }\end{array}$ & $\begin{array}{l}\text { Secundária tardia. } \\
\text { Secundária tardia. } \\
\text { Secundária. } \\
\text { Secundária. }\end{array}$ \\
\hline Lythraceae & $\begin{array}{l}\text { Lafoensia glyptocarpa } \\
\text { Lafoensia pacari } \\
\text { Lagerstroemia indica } \\
\text { Lagerstroemia speciosa }\end{array}$ & $\begin{array}{l}\text { Koehne. } \\
\text { St. Hil. } \\
\text { L. } \\
\text { (L.) Pers. }\end{array}$ & $\begin{array}{l}\text { Secundária tardia. } \\
\text { Secundária tardia. } \\
\text { Exótica } \\
\text { Exótica }\end{array}$ \\
\hline Magnoliaceae & $\begin{array}{l}\text { Michelia champaca } \\
\text { Talauma obovata }\end{array}$ & $\begin{array}{l}\text { L. } \\
\text { A. St.-Hill }\end{array}$ & $\begin{array}{l}\text { Secundária tardia. } \\
\text { Secundária tardia. }\end{array}$ \\
\hline Melastomataceae & $\begin{array}{l}\text { Miconia cinnamomifolia } \\
\text { Tibouchina mutabilis } \\
\text { Tibouchina sellowiana }\end{array}$ & $\begin{array}{l}\text { (DC.) Naudin. } \\
\text { (Vell.) Cogn. } \\
\text { (Cham.) Cogn }\end{array}$ & $\begin{array}{l}\text { Secundária tardia. } \\
\text { Pioneira. } \\
\text { Pioneira. }\end{array}$ \\
\hline Meliaceae & $\begin{array}{l}\text { Cabralea canjerana } \\
\text { Cedrela fissilis } \\
\text { Guarea macrophylla }\end{array}$ & $\begin{array}{l}\text { (Vell.) Mart. } \\
\text { Vell. } \\
\text { Vahl. }\end{array}$ & $\begin{array}{l}\text { Secundária inicial. } \\
\text { Secundária inicial. } \\
\text { Secundária tardia. }\end{array}$ \\
\hline
\end{tabular}


Tabela 2. Lista das espécies usadas na restauração da área B (área de estudo em Iracemápolis, SP), de acordo com a família e categoria sucessional.

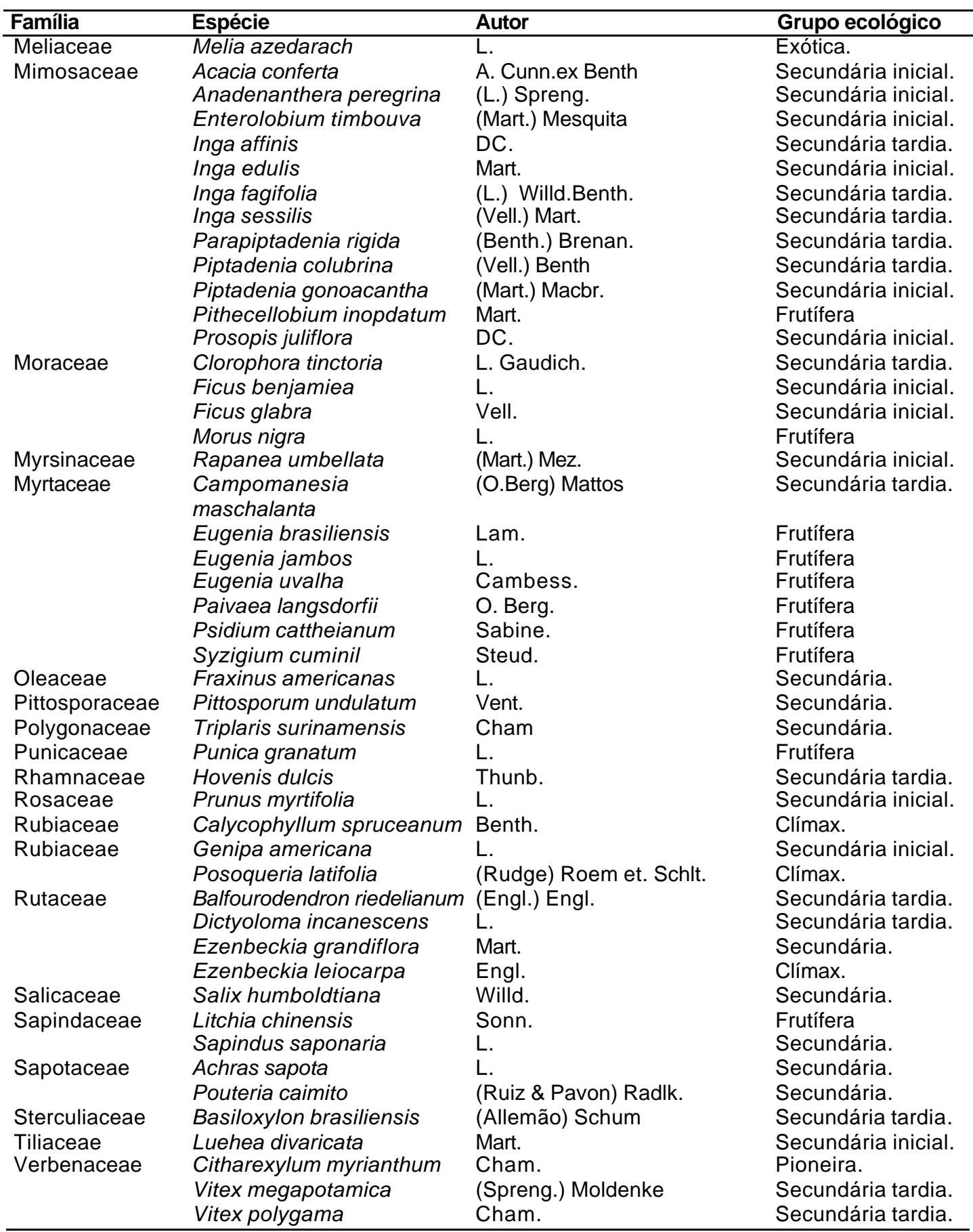


Anexo B

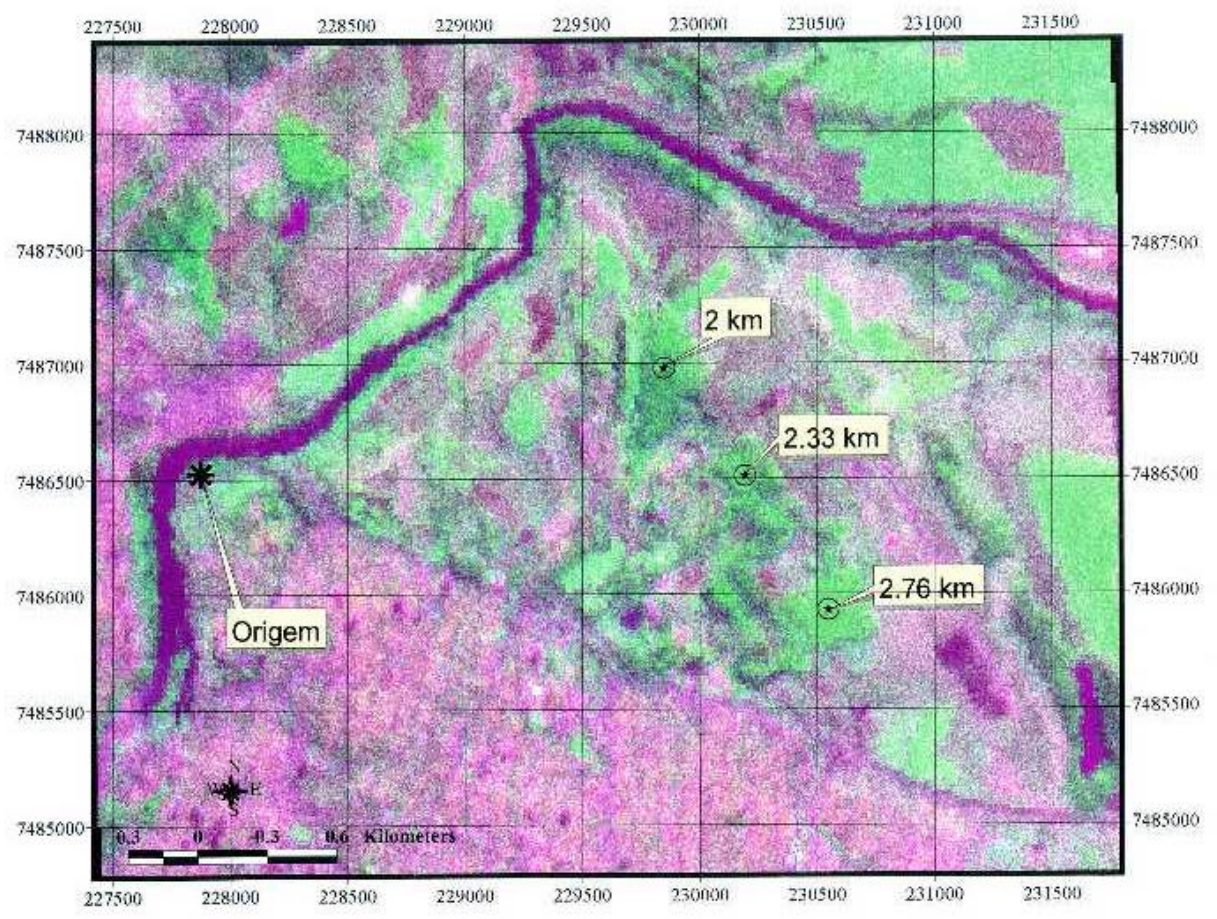

Figura 1 - Imagem de satélite - (Imagem Spot-Falsa composição colorida, Band 2,3,1) da área $\mathrm{A}$ (área de estudo em Piracicaba, SP), indicando a área de palntioOrigem, às margens do rio Piracicaba, e a distância dos fragmentos mais próximos 


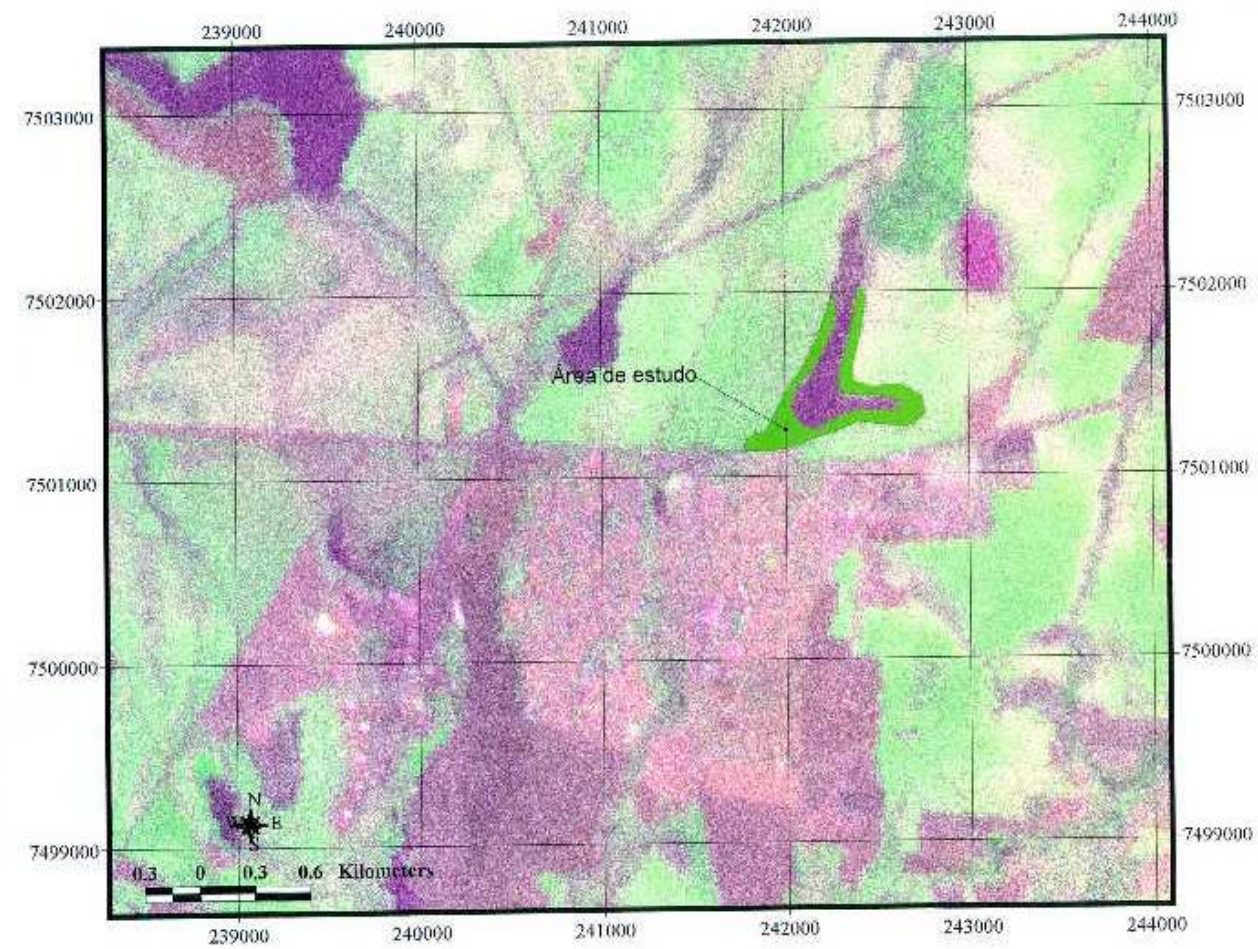

Figura 2 - Imagem de satélite- (Imagem Spot-Falsa composição colorida, Band 2,3,1) da área B (área de estudo em Iracemápolis, SP), com detalhe da área de do plantio às margens da respesa de abastecimento municipal. 
Anexo C

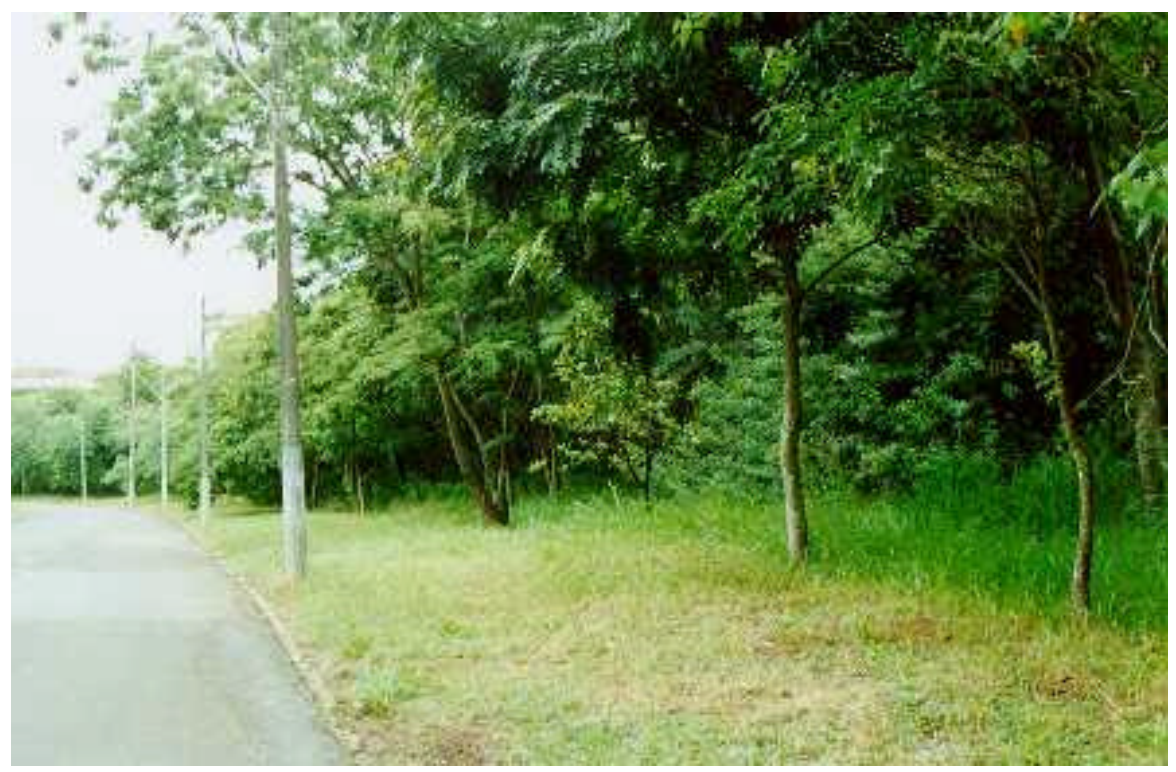

Figura 3 - Vista da área A, área de estudo na cidade de Piracicaba (SP), dentro do perímetro urbano, mostrando a avenida ao lado do plantio.

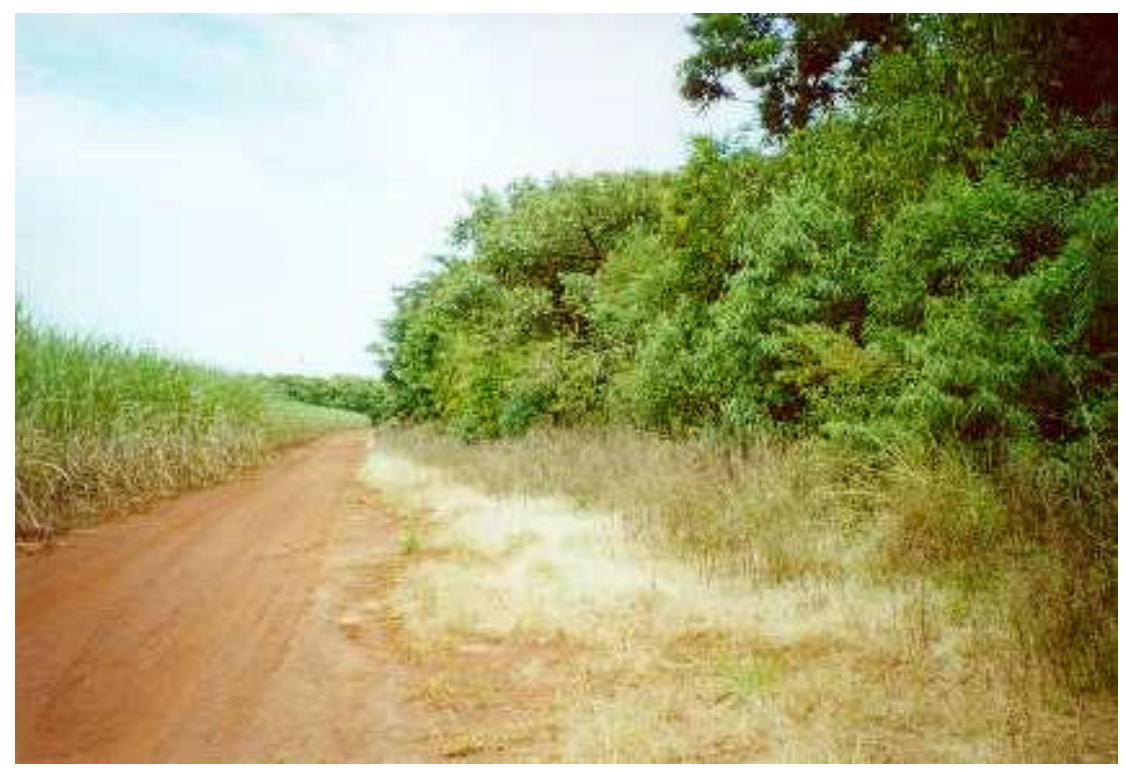

Figura 4 - Vista da área B, área de estudo no município de Iraemáplis (SP), com detalhe da estrada de terra que separa o plantio da área de entorno, dominada por cultura de cana-de-açúcar. 


\section{REFERÊNCIAS BIBLIOGRÁFICAS}

AIDE, M.T.; ZIMMERMAN, J.K.; PASCARELLA, J.B.; MARCANO-VEJA, H.; Forest regeneration in a chronosequence of tropical abandoned pastures: implications for restoration ecology. Restoration Ecology, v.8, n.4, p.328-338, 2000.

AIDE, M.T.; ZIMMERMAN, J.K.; HERRERA, L.; ROSARIO, M.; SERRANO, M. Forest recovery in abandoned tropical pastures in Puerto Rico. Forest Ecology and Management, v.77, p.77-86, 1995.

ALVAREZ-BUYLLA, E. R.; MARTINEZ-RAMOS, M. Seed banck versus seeed rain in the regeneration of a tropical pioneer tree. Oecologia, v. 84, p. 314-325, 1990.

ALVAREZ-BUYLLA, E.R.; MARTINEZ-RAMOS, M. Demography and allometry of Cecropia obtusifolia, a neotropical pioneer tree- an evaluation of the climax- pioneer paradigm for tropical rain forests. Journal of Ecology, v. 80, p. 275-290, 1992.

ALVAREZ-BUYLLA, E. R.; CHAOS, A.; PIÑERO, D.; GARAY, A.A. Demographic genetics of a pioneer tropical tree species: patch dynamics, seed dispersal, and seed banks. Evolution, v.50, n.3, 1155-1166, 1996.

ANDERSEN, A.N.; MORRISON, S.C. Myrmecochory in Australia's seasonal tropics: Effects of disturbance on distance dispersal. Australian Journal of Ecology, v.23, p.483-491, 1998.

ANDERSEN, A.N.; SPLARLING, G.P. Ants as indicators of restoration success: relationship with soil microbial biomass in the Australian seasonal tropics. Restoration Ecology, v.5, n.2, p.109-114, 1997. 
ARMSTRONG, K.N.; NICHOLS, O.G. Long-term trends in avifaunal recolonisation of rehabilitated bauxite mines in the jarrah forest of south-western Australia. Forest Ecology and Management, v.126, p.213-225, 2000.

ARÉVALO, J.R.; FERNÁNDEZ-PALACIOS, J.M. Seed bank analysis of tree spicies in two stands of Tenerife laurel forest (Canary Islands). Forest Ecology and Management, v.130, p.177-185, 2000.

ARONSON, J.; LE FLOC'H, E. Vitla land attributes: missing tools for forest restoration ecology. Restoration Ecology, v.4, n.4, p.377-387, 1996.

AUGUSTO, L.; DUPOUEY, J. L., PICARD, J.F.; RANGER, J. Potential contribution of the seed bank in coniferous plantation to the restoration of native deciduous forest vegetation. Acta Oecologica, v.22, p.87-98, 2001.

BAIDER, C. O banco de sementes e de plântulas na sucessão da Mata Atlântica. São Paulo, 1994. 137p. Dissertação (Mestrado) - Instituto de Biociência, Universidade de São Paulo.

BAIDER, C.; TABARELLI, M.; MANTOVANI, W. O banco de sementes de um trecho de floresta Atlântica Montana (São Paulo, Brasil). Revista Brasileira de Biologia, v.59, n.2, p.319-328, 1999.

BAIDER, C.; TABARELLI, M.; MANTOVANI, W. The soil seed bank during atlantic forest regeneration in southeast Brazil. Revista Brasileira de Biologia, v.61, n.1, p.35-44, 2001.

BARBOSA, L.M. Considerações gerais e modelos de recuperação de formações ciliares. In: RODRIGUES, R.R.; LEITÃO-FILHO, H.F. (Ed.) Matas ciliares: conservação e recuperação. São Paulo: EDUSP, 2000. cap.15.4, p.289-312.

BARTON, C.; NELSON, E. A.; KOLKA, R.K; MCLEOD, W.K.; CONNER, W.H.; LAKLY, M.; MARTIN, D.; WIGGINTON, J.; TRETTIN, C.C.; WISNIEWSKI, J. Restoration of a severely impacted riparian wetland system - The Pen branch project. Ecological Engineering, v.15, p.3-15, 2000. 
BEGON, M.; HARPER, J. L. TWONSEND, C. D.; Ecology: individuals, populations and communities. 3. ed. Oxford: Blackwell, 1990. 1068p.

BEKKER, R.N.; VERWEIJ, G.L.; BAKKER, J.P.; FRESCO, L.F.M. Soil seed bank dynamics in hayfield succession. Journal of Ecology, v.88, p.594-607, 2000.

BELL, S.S.; FONSECA, M.A.; MOTTEN, L.B. Linking restoration ecology and landscape ecology. Restoration Ecology, v.5, n.4, p.318-323, 1997.

BENTHAM, H.; HARRIS, J.A.; BIRCH, P. SHORT, K.C. Habitat classification and the soil restoration assessment using analysis of soil microbiological and physicochemical characteristic. Journal of Applied Ecology, v.29, p.711-718, 1992.

BIERREGAARD, R.O. JR., LOVEJOY, T.E., KAPOS, V., SANTOS, A.A.; HUTCHINGS, W. The biological dynamics of tropical rainforest fragments. BioScience, v.42, p.859866,1992 .

BROKAW, N.V.L.; SCHEINER, S.M. Species composition in gaps and structure of a tropical forest. Ecology, v.70, n.3, p.538-541, 1989.

BROWN, D. Estimating the composition of a forest seed bank: a comparison of the seed extraction and seedling emergence methods. Canadian Journal of Botany, v.70, p.1603 -1612, 1992.

BROWN, S.; LUGO, A.E. Tropical secondary forests. Journal of Tropical Ecology, v.6, p.109-114, 1990.

BUDOWSKI, G. Distribution of tropical American rain forest species in the ligth of successional processes. Turrialba, v.15, n.1, p.40-42, 1965.

BUTLER, B.J.; CHAZDON, R.L. Species Richness, Spatial Variation, and Abundance of the soil seed bank of a secundary tropical rain forest. Biotropica, v.30, n.2, p.214222, 1998.

CALDATO, S.L.; FLOSS, P.A.; CROCE, D.M.; LONGHI, SJ. Estudo da regeneração natural, banco de sementes e chuva de sementes na Reserva Genética Florestal do Caçador, SC. Ciência Florestal, v.6, p.27-38, 1996. 
CASTRO MAYA, R.O. A. Floresta da Tijuca. Rio de Janeiro: Ed.Bloch, 1967. 102p.

CHAPMAN, C. A.; CHAPMAN, L. J. Exotic tree plantations and the regeneration of natural forest in Kibale National Park, Uganda. Biological Conservation, v.76, p.253-257, 1996.

CLARK, D.B.; CLARK, D.A. The role of physical damage in the seedling mortality regime of a neotropical rain forest. Oikos, v.55, p.225-230, 1989.

CLARK, D.B.; CLARK, D.A. Comparative analysis of microhabitat utilization by saplings of nine tree species in neotropical rain forest. Biotropica, v.25, n.4, p.397-407, 1993

CLARCK, C.J.; POULSEN, J.R.; PARKER, V.T. The role of arboreal seed dispersal groups on the seed rain of lowland tropical forest. Biotropica, v.33, n.4, p.606-620, 2001.

CONNEL, J.H.; SLATYER, R.O. Mechanisms of succession in natural communities and their role in community stability and organization. American Naturalist, v.111, p.1119-1144, 1977.

DALLING, J. W. ; SWAINE, M. D.; GARWOOD, N. C. Soil seed bank community dynamics in seasonally moist lowland tropical forest, Panama. Journal of Tropical Ecology, v.13, p.659-680, 1997.

DALLING, J. W.; HUBBELL, S.P.; SILVERA, K. Seed dispersal, seedling estlablishment and gap partitioning among tropical pioneer trees. Journal of Ecology, v.86, p.674689, 1998.

DENSLOW, J. S. Gap partioning among tropical rain forest trees. Biotropica, v.12, p.47-55, 1980.

DENSLOW, J.S. Tropical rain forest gaps and tree species diversity. Annual Review of Ecology and Systematics, v.18, p.431-451, 1987.

DENSLOW, J. S. Disturbance and diversity in tropical rain forest: the density effect. Ecological Applications, v.5, n.4, p.962-968, 1995. 
DIDHAM, R.K.; LAWTON, J.H. Edge structure determines the magnitude of changes in microclimate and vegetation structure in Tropical Forest Fragments. Biotropica, v.31, n.1, p.17-30, 1999.

EHRENFELD, J.G.; TOTH,L.A. Restoration ecology and the ecosystems perspective. Restoration Ecology, v.5, n.4, p.307-317,1997.

FACCELLI, J.M.; PICKETT, S.T.A. Plant litter: its dynamics and effects on plant community structure. The Botanical Review, v.57, p.1-32, 1991.

FINEGAN, B. The management potential of Neotropical secondary lowland rain forest. Forest Ecology and Management, v.47, p.295-321, 1992.

FINEGAN, B.; DELGADO, D. Structural and floristic heterogeneity in a 30-year-old Costa Rican rain forest restored on pasture through natural secondary succession. Restoration Ecology, v.8, n.4, p.380-393, 2000.

FINIZI, A.C.; CANHAM, C.D., . Sapling growth in response to light and nitrogen availability in a southern New England forest. Forest Ecology and Management, v.131, p.153-165, 2000.

FÜHRER, E. Forest functions, ecosystem stability and management. Forest Ecology and Managament, v.132, p.29-38, 2000.

GANDOLFI, S. Estudo florístico e fitossociológico de uma floresta residual na área do aeroporto Internacional de São Paulo, município de Guarulhos, SP. Campinas, 1991. 232p. Dissertação (Mestrado) - Instituto de Biologia, Universidade Estadual de Campinas

GANDOLFI, S. História natural de uma floresta estacional semidecidual no municípo de Campinas (São Paulo, Brasil). Campinas, 2000. 519p. Tese (Doutorado) - Instituto de Biologia, Universidadde Estadual de Campinas.

GARWOOD, N. C. Seed germination in seasonal tropical forest in Panama: a community study. Ecological Monographs. v. 53, n.2, p.159-181,1983. 
GELDENHUYS, C.J.; Native forest regeneration in pine and eucalyptus plantations in Northern Province, South Africa. Forest Ecology and Management, v.99, p.101115, 1997.

GEORGE, L.O.; BAZZAZ, F.A. The fern understory as na ecologycal filter: emergence and establishment of canopy-tree seedlings. Ecology, v.80, n.3, p.833-845, 1999a.

GEORGE, L.O.; BAZZAZ, F.A. The fern understory as na ecologycal filter: growth and survival of canopy-tree seedlings. Ecology, v. 80, n.3, p.846-856, 1999b.

GRAYSON, J.E.; CHAPMAN, MG.; UNDERWOOD, A.J. The assessment of restoration of habitat in urban wetlands. Landscape and Urban Planning, v.43, p.227-236, 1999.

GROMBONE-GUARATINI, M. T. Banco de sementes de uma floresta ripária no Rio Mogi-guaçu, SP. Campinas, 1993. 100p. Dissertação (Mestrado) - Instituto de Biologia, Universidade Estadual de Campinas.

GROMBONE-GUARATINI, M. T. Dinâmica de uma Floresta estacional semidecidual: o banco, a chuva de semente e o estrato de regeneração. São Paulo, 1999. 150p. Tese (Doutorado) - Instituto de Biologia, Universidade Estadual de São Paulo.

GUARIGUATA, M. R. Response of forest tree to experimental mechanical damage in lowland Panama. Forest Ecology and Management, v.102, p.103-111, 1998.

GUARIGUATA, M.R. Seed and seedling ecology of tree spicies in neotropical secundary forest: Management implications Ecological Applications, v.10, n.1, p.145-154, 2000.

GUARIGUATA, M.R.; OSTERGA, R. Neotropical secondary forest succession: changes in structural and functional characteristics. Forest Ecology and Management, v.148, p.185-206, 2001. 
GUARIGUATA, M R.; PINARD, M. A Ecological knowledge of regeneration from seed in neotropical forest trees: Implications for natural forest management. Forest Ecology and Management, v.112, p.87-99, 1998.

GUO, Q.; BROWN, J. H.; VALONE, T. H.; KACHMAN. S.D. Constraints of seed size on plant distribution and abundance. Ecology, v.81, n.8, p.2149-2155, 2000.

HAGGAR, J.; WIGHTMAN, K; FISHER, R. The potential of plantations to foster woody regeneration within a deforested landscape in lowland Costa Rica. Forest Ecology and Management, v.99, p.55-94, 1997.

HARPER, J. L. Population biology of plants. London: Academic press, 1997. 892p.

HOWE, H.F.; SMALLWOOD, J. Ecology of seed dispersal. Annual Revview of Ecology and Systematics, v.13, p.201-218, 1982.

HOLL, K.D. Factors limiting tropical rain forest regeneration in abandoned pasture: seed rain, seed germination, microclimate, and soil. Biotropica, v.31, n.2, p.22942,1999 .

HYATT, L.A.; CASPER, B.B. Seed bank formation during early secondary succession in temperate deciduous forest. Journal of Ecology, v.88, p.516-527, 2000.

FUNDAÇÃO INSTITUTO BRASILEIRO DE GEOGRAFIA E ESTATÍSTICA. Manual técnico da vegetação Brasileira. Rio de Janeiro, 1992. 91p. (Série Manuais Técnicos de Geociências).

JACKSON, L.; LOPOUKHINE, N.; HILLYARD,D. Ecological restoration: a definition and comments. Restoration Ecology, v.3, n.2, p.71-75, 1997.

JANSEN, A Terrestrial invertebrate community structure as an indicator of success of a tropical rainforest restoration project. Restoration Ecology, v.5, n.2, p.115-124, 1997.

JANSEN, D.H. Herbivores and the number of tree spicies in tropical forest. The American Naturalist, v.23, p.1-27, 1970. 
JURADO, E.; FLORES, J.; NAVAR, J.; JIMÉNEZ, 」 Seedling establishment under native tamaulipan thornscrub and Leucaena leucocephala palntation. Forest Ecology and Management, v.105, p.151-157. 1998.

KAGEYAMA, P.; GANDARA, F.B. Recuperação de áreas ciliares. In: RODRIGUES, R.R.; LEITÃO-FILHO, H.F. (Ed.) Matas ciliares: conservação e recuperação. São Paulo: EDUSP, 2000. cap.15.2, p.249-269.

KALISZ, S.; HANZAWA, F.M.; TONSOR, S.; THEIDE, D.A.; VOIGT,S. Ant-mediated seed dispersal alters pattern of relatedeness in a population of Trillium grandiflorum. Ecology, v.80, n.8, p.2620-2634, 1999.

KEENAN, R.; LAMB, D; WOLDRING,O.; RVINE, T.; JENSEN, R. Restoration of plant biodiversity beneath tropical tree plantations in Northern Australia. Forest Ecology and Management, v.99, p.117-131, 1997.

KENDLE, A. D.; ROSE,J.E. The aliens have landed! What are the justifications for 'native only' polices in landscape plantings? Landscape and Urban Planning, v.47, p.19-31, 2000.

KOBE, P.K. Light gradient partitioning among tropical tree species through differential seedling mortality and growth. Ecology, v.80, n.1, p.187-201, 1999.

KOLKA, R. K.; NELSON, E. A.; TRETTIN, C. C. Conceptual assessment framework for forested wetland restoration: the Pen Branch experience. Ecological Engineering, v.15, p.17-21, 2000.

LASKA, M. S. Structure of understory shrub assemblages in adjacent secondary and old growth tropical wet forest, Costa Rica. Biotropica, v.29, n.1, p.29-37, 1997.

LAURANCE, W.F. Introduction and synthesis. Biological Conservation, v.91, p.101107, 1999.

LAURANCE, W.F.; FERREIRA, L.V.; MERONA, J.M.R.; LAURANCE, S.G. Rain forest fragmentation and the dynamics of Amazonian tree communities. Ecology, v.79, p.2032-2040, 1998. 
LEOPOLD, A. C.; ANDRUS, R.; FINKELDEY, A; KNOWLES, D. Attempting restoration of wet tropical forests in Costa Rica. Forest Ecology and Management, v.142, p.243-249, 2001.

LÓPEZ-MARIÑO, A.; LUIS-CALABUIG, E. FILLAT, F.; BERMUDEZ F. F. Floristic composition of established vegetation and the soil seed bank in pasture communities under different traditional management regimes. Agriculture Ecossistems \& Enviroment, v.78, p.273-282, 2000.

LUGO, A. The apparent paradox of reestablishing species richness on degraded lands with tree monocultures. Forest Ecology and Management, v.99, p.9-19, 1997.

LUNT, I.D. Germinable soil seed banks of anthropogenic native grasslands and grassy forest remnants in temperate south-eastern Australia. Plant Ecology, v.130, p.21$34,1997$.

MAJER, J.D. Ant recolonization of rehabilitated bauxite mines at Trombetas, Pará, Brazil. Journal of Tropical Ecology, v.12, p.257-273, 1996

MAJER, J.D.; NICHOLS, O.G. Long-term recolonization patterns of ants in Western Australian rehabilitated bauxite mines with reference to their use as indicators of restoration success. Journal of Applied Ecology, v.35, p.161-182, 1998.

MANSON, R.H., OSTFELD, R.S., CANHAM, C.D. Responses of a small mammal community to heterogeneity along forest-old-field edges. Landscape Ecology, v.14, p.355-367, 1999.

MARTÍNEZ-RAMOS, M; SOTO-CASTRO, A. Seed rain and advanced regenaration in tropical rain forest. Vegetatio, v.107/108, p.299-318, 1993.

MARTINS, H. F. Relatório técnico para avaliação dos projetos de reflorestamento no Município do Rio de Janeiro - Feema. Rio de Janeiro: Pronol;Condir, 1988. 42p.

MATLACK, G.R.; Microenvironment variation within and among forest edge sites in the eastern united states. Biological Conservation, v.66, p.185-194, 1993. 
McCLANAHAN, T.R. WOLFE, R.W. Accelerating forest succession in a fragmented landscape: The role of birds and perches. Conservation Biology, v.7, n.2, p.279288, 1993.

McDONALD, A.W.; BAKKER, J.P.; VEGELIN, K. Seed bank classification and its importance for the restoration of species-rich flood-meadows. Journal of Vegetation Science, v.7, p.157-164, 1996.

MESQUITA, R. C. G; Management of advanced regeneration in secondary forest of the Brazilian Amazon. Forest Ecology and Management, v.130, p.131-140, 2000.

MICHENER, W. K Quantitatively evaluating restoration experiments: research design, statistical analysis, and data management considerations. Restoration Ecology, v.5, n.4, p.324-337, 1997.

MONTALVO, A. M.; WILLIAMS, S. L.; RICE, K. J.; BUCHMANN, S. L.; CORY, C.; HANDEL, S. N.; NABHAN, G. P.; PRIMACK, R; ROBICHAUX, R. H. Restoration biology: a population biology perspective. Restoration Ecology, v.5, n.4, p.277290, 1997.

MORELLATO, L.P.C; LEITÃO-FILHO, H.F. Padrões de frutificação e dispersão na Serra do Japi. In:MORELLATO, L.P.C. (Org.). História natural da Serra do Japi: eologia e preservação de uma área florestal no sudeste do Brasil. Campinas: UNICAMP;FAPESP, 1992. cap.7, p.112-141.

MÜELLER-DOMBOIS, D.; ELLENBERG, H. Aims and methods of vegetation ecology. New York: Wiley, 1974. 574p.

MURCIA, C. Edge effects in fragmented forests: implications for conservation. Trends in Ecology \& Evolution, v.10, p.58-62, 1995.

NATHAN, R. The challenges of studying dispersal. Trends in Ecology \& Evolution, v.16, n.9, p.481-483, 2001.

NEPSTAD, D.C.; UHL, C.; PEREIRA, C.A.; SILVA, J.M.C. A comparative study of tree establishement in abandoned pasture and mature forest of eastern Amazonia. Oikos, v.76, p.25-39, 1996. 
ONAINDIA, M.; AMEZAGA, I. Seasonal variation in the seed banks of native woodland and coniferous plantations in Northern Spain. Forest Ecology and Management, v.126, p.163-172, 2000.

PALLER, M.H.; REICHERT, M.J.M.; DEAN, J.M.; SEIGLE, J.C. Use of fish community data to evaluate restoration success of a riparian stream. Ecological Engineering, v.15, p.171-187, 2000.

PALMER, M.A.; AMBROSE, R.F.; LEROY, N. Ecological Theory and Community Restoration Ecology. Restoration Ecology, v.5, n.4, p.291-300, 1997.

PARKER, V.T. The Scale of Successional Models and Restoration Objectives. Restoration Ecology. v.5, n.4, p.301-306, 1997.

PARROTA, J.A. Influence of overstory composition on understory colonization by native species in plantations on a degradaded tropical site. Journal of Vegetation Science, v.6, p.627-636, 1995

PARROTA, JA. Productivity, nutrient cycling, and succession in single and mixedspecies plantations of Casuarina equisetifolia, Eucalyptus robusta and Leucaena leucocephala in Puerto Rico. Forest Ecology and Management, v.124, p.45-77, 1999.

PARROTA, J.A.; KNOWLES, O.H.; Restoration of tropical moist forest on BauxiteMined Lands in the Brazilian Amazon. Restoration Ecology, v.7, n.2, p.103-116, 1999.

PARROTA, J.A.; KNOWLES, O. H.; Restoring forest on lands mined for bauxite: Exemples from the Brazilian Amazon. Ecological Engineering, v.17, p.219-239, 2001.

PARROTA, J.A.; KNOWLES, O.H; WUNDERLE JR., J.M. Development of floristic diversity in 10-year old restoration forest on bauxite mined site in Amazonia. Forest Ecology and Managemente, v.99, p.21-42, 1997a.

PARROTA, J.A.; TURNBULL, J. W.; JONES, N. Catalyzing native forest regeneration on degraded tropical lands. Forest Ecology and Management, v.99, p.1-7, 1997b. 
PENHA, A.S. Propagação vegetativa de espécies arbóreas a partir de raízes gemíferas: representatividade na estrutura fitossociológica e descrição dos padrões de rebrota de uma comunidade florestal, Campinas, 1998. 114 p. Tese (Mestrado) Departamento de Biologia Vegetal, Universidade Estadual de Campinas.

PENHALBER, E.F; MANTOVANI, W. Floração e chuva de sementes em mata secundária em São Paulo, SP. Revista Brasileira de Botânica, v.20, p.205-220, 1997.

PICKETT, S.T.A.; OSTFELD, S.R. The shifiting paradigm in Ecology. In: KRUGHT, R.L.; BATES, S.F (Ed.) A new century for natural resources management. Washington: Island Press, 1994. cap.15, p. 261-278.

PICKETT, S.T.A.; PARCKER, V.T.; FIEDLER, P. L. The new paradigm in Ecology: Implications for conservation biology above the species evel. In: FIELDLER, P.L.; JAIN, S.K. (Ed.) Conservation Biology. New York: Chapman and Hall, 1992. cap. 4, p.65-88.

POWER, J.S.; HAGGAR, J.P.; FISHER, R.F. The effect of overstory composition on understory woody regeneration and species richness in 7year-old plantations in Costa Rica. Forest Ecology and Management, v.99, p.43-54, 1997.

PRABHU, R.; COLFRER, C.J.P.; VENKATESWARLU, P.; TAN, L.C.; SOEKMADI, R.; WOLLENBERG, E. Testing criteria and indicators for sustainable management of forest: phase 1, final report. Jakarta: CIFOR, 1996, 83p. (CIFOR Special Publication).

PRIMACK, R.B. Essentials of conservation biology. Sunderland: Sinauer, 1993. $178 \mathrm{p}$.

QUINTANA-ASCENCIO, P.F.; GONZÁLEZ-ESPINOSA, M.; RAMÍREZ-MARCIAL, N.; VÁZQUEZ-DOMÍNGUEZ, G.; MARTíNEZ-ICÓ, M. Soil seed banks and regeneration of forest from Milpa Fields at the Selva Lacandona, Chiapas, Mexico. Biotropica, v.28, n.2, p.192-209, 1996. 
REIS, A., ZAMBONIN, R.M., NAKAZONO, E.M. Recuperação de áreas degradadas utilizando a sucessão e as interações planta-animal. Cadernos da Reserva da Biosfera da Mata Atlântica, n.14, p.1-42, 1999.

ROBINSON, G. R.; HANDEL. S. N. Forest Restoration on a closed Landfill: Rapid Addition of New Species by Bird Dispersal. Conservation Biology, v.7, n.2, p.271278, 1992.

RODRIGUES, R. R.; GANDOLFI, F. Conceitos, tendências e ações para a recuperação de florestas ciliares. In: RODRIGUES, R. R.; LEITÃO-FILHO, H. F. (Ed.) Matas ciliares: Conservação e Recuperação. São Paulo: EDUSP, 2000. cap.15.1, p.235248.

RODRIGUES, R. R., GANDOLFI, F. Recomposição de florestas nativas: princípios gerais e subsídios para uma definição metodológica. Revista Brasileira de Horticultura Ornamental, v.2, n.1, p.4-15, 1996.

RODRIGUES, R.R. Colonização e enriquecimento de um fragmento florestal urbano após ocorrência de fogo, Fazenda Sata Eliza, Campinas, SP: Avaliação temporal da regeneração natural (66 meses) e de crescimento $(51$ meses) de 30 espécies florestais plantadas em consórcio de mudas. Piracicaba, 1999. 167 p. Tese (Livre Docência) -Escola Superior de Agricultura "Luiz de Queiroz", Universidade de São Paulo.

RODRIGUES, R.R., LEITÃO-FILHO, H.F., CRESTANA, M.S.M. Revegetação do entorno da represa de abastecimento de água do município de Iracemápolis/ SP. In: SIMPÓSIO NACIONAL DE RECUPERAÇÃO DE ÁREAS DEGRADADAS. Curitiba,1992. Anais. Curitiba: FUPEF, 1992. p.406-414.

ROIZMAN, L. C. Fitossiologia e dinâmica do banco de semente de populações arbóreas de florestas secundárias em São Paulo - SP. São Paulo, 1993. 69p. Dissertação (Mestrado) - Instituto de Biociências, Universidade de São Paulo.

ROZZA, A., RODRIGUES, R.R., LIMA, A.M.L.P., Rochas, Y.T. Revegetação de um trecho de mata às margens do rio Piracicaba em área urbana do município de 
Piracicaba, SP. In: CONGRESSO BRALILEIRO SOBRE ARBORIZAÇÃO URBANA, Vitória, 1992. Anais. Vitória: Prefeitura, 1992. v.2, p.253-270.

SAUNDERS, D.A.; HOBBS, R.J.; MARGULES, C. R.. Biological consequences of ecosystem fragmentation: a review. Conservation Biology, v.5, p.18-32, 1991.

SCARIOT, A. Forest fragmentation effects on palm diversity in cental Amazonia. Journal of Ecology, v. 87, p. 66-76, 1999

SCARIOT, A. Seedling mortality by litterfall in Amazonian forest fragments. Biotropica, v.32, p.662-669, 2000.

SCHNITZER, S.A.; CARSON, W.P. Treefall and the maintenance of species diversity in a tropical forest. Ecology, v.82, n.4, p.913-919, 2001.

SCHUPP, E.W. Seed and early seedling predation in the forest understory and in treefall gaps. Oikos, p. 51, v. 71-78, 1988.

SILVER, L.W.; OSTERTAG, R.; LUGO, A. E. The potential for carbon sequestration trough reforestation of abandoned tropical agricultural and pasture lands. Restoration Ecology, v.8, n.4, p.394-407, 2000.

SKOGLUND, J. The role of seed banks in vegetation dynamics and restoration of dry tropical ecosystems. Journal of Vegetation Science, v.3, p.357-360, 1992.

SOUZA, F.M. Estrutura e dinâmica do estrato arbóreo e da regeneração natural em áreas restauradas. Piracicaba, 2000. 69p. Dissertação (Mestrado) - Escola Superior de Agricultura "Luiz de Queiroz", Universidade de São Paulo.

STRYKSTRA, R.J., BEKKER, R.M., BAKKER, J.P. Assessment of dispersule avaibility: its practical use in restoration management. Acta Botanica Neerlandica, v.47, n.1, p.57-70, 1998.

SWAINE, M.D.; WHITMORE, T.C. On the definition of ecological spices groups in tropical rain forest. Vegetation, v.75, p.81-86, 1988.

TEKLE, K.; BEKELE, T. The role of soil seed bank in the rehabilitation of degraded Hillslopes in Southern Wello, Ethiopia. Biotropica, v. 32, n.1, p.23-32, 2000. 
TERBORGH, J, LOSOSE., RILEY, M.P.; RILEY, M.B. Predation by vertebrates and invertebrates on the seeds of fiv canopy tree spicies of na Amazonian forest. Vegetatio, v.107/108, p.375-386, 1993.

THOMPSON, K.; GRIME, J.P. Seasonal variation in the seed banks of herbaceous species in tem contrasting habitats. Journal of Ecology, v.67, p. 893-921, 1979.

THOMPSON, K.; BAKKER, J.P.; BEKKER, R.M.; HODGSON, J.G. Ecological correlates of seed persistence in soil in the north-west European flora. Journal of Ecology, v. 86, p.163-169, 1998.

TURKER, N.I.J.; MURPHY, T.M. The effects of ecological rehabilitation on vegetation recruitment: some observations from the wet tropics of North Queensland. Forest Ecology and Management, v.99, p.133-152, 1997.

TURNER, I.M. Species loss in fragments of tropical rain forest: a review of the evidence. Journal of Applied Ecology, v.33, p.200-209, 1996.

UHL, C.; BUSCHBACHER, R.; SERRÃO, E.A.S. Abandoned pastures in eastern Amazonia. I. Patterns of plant succession. Journal of Ecology, v.76, p.663-681, 1988.

VAN AARDE, R.J.; FERREIRA, S.M.; KRITZINGER, J.J.; VAN DYK, P.J.; VOGT, M.; WASSENAAR,T.D. An evaluation of habitat rehabilitation on costal dune forest in northeern Kwazulu-Natl, South Africa. Restoration Ecology, v.4, n.4, p.334-345, 1996.

VÁZQUEZ-YANES, C; OROZCO-SEGOVIA, A. Patterns of seed longevity and gemination in the tropical rain forest. Annaul Review of Ecology and Systematics, v.24, p.69-87, 1993.

VAN BUEREN, E.M.L.; BLOM, E M. Hierarchical framework for the formulation of sustainable forest management: principles, criteria, indicators. Leiden: Tropenbos Foudantion,1997. 82p.

WHITMORE, T.C. On pattern and process in forest. In: NEWMAN, E.T. (Ed.) The plant community as a working mechanism. 2. ed. Oxford: Blackwell, 1982. p.45-59. 
WIJDEVEN, S.M.J.; KUZEE, M.E. Seed availability as a limiting factor in forest recovery processes in Costa Rica. Restoration Ecology, v.8, n.4, p.414-424, 2000.

WILLIAMS-LINERA, G. Soil seed bank in four lowe montane forests of Mexico. Journal of Tropical Ecology, v.9, p.321-337, 1993.

WILLSON, M.F. Dispersal mode, seed shadows, and colonization patterns. Vegetatio, v.107/108, p.216-280, 1993.

WUNDERLE JUNIOR, J. M. The role of animal seed dispersal in accelerating native forest regeneration on degraded tropical lands. Forest Ecology and Management, v.99, p.223-235, 1997.

YONG, K. R.; EWEL, JJ.; BROWN, B.J. Seed dynamics during forest sucession in Costa Rica. Vegetatio, v.71, p.157-173, 1987.

YOUNG, T.P. Restoration ecology and conservation biology. Biological Conservation, v.92, p.73-83, 2000.

ZOU, X.; GONZALEZ, G. Changes in Earthworm density and community structure during secondary succession in abandoned tropical pastures. Soil Biology \& Biochemistry, v.29, n3/4, p.627-629, 1997. 